\title{
Wet 'n Wild: When Water Rides Should be Subject to the Highest Duty of Care
}

\author{
Paul Mose*
}

\section{INTRODUCTION}

Two thrill ride accidents in July 2013 - one involving a woman who fell seventy-five feet to her death from a roller coaster, ${ }^{1}$ and another involving a log flume that overturned and trapped seven patrons underwater ${ }^{2}$ - placed national attention on the safety of amusement park rides. $^{3}$ Following the accidents, social media erupted with calls for increased ride safety. ${ }^{4}$ At the same time, a Kansas waterpark was completing construction on the world's "tallest, fastest and 'most extreme' water slide ever built" - the Verrückt, which is "German for insane." A target for "adrenaline junkies who are always looking for the

\footnotetext{
* J.D. Candidate 2015, University of Kansas School of Law; B.S. 2012, Emporia State University. I would like to thank my wife, Melissa, who has put up with me since second grade, never once complained about the demands of law school, and made every single day better. Thanks to my mom and sister for the daily prayers, laughs, and keeping me in check. I would also like to thank Professor William Westerbeke for his invaluable insight and feedback. And to all the professors, librarians, and staff at KU: Rock Chalk!

1. See, e.g., Ryan Owens, Family Sues Six Flags After Woman's Fall from 14-Story High Roller Coaster, ABC NEwS (Sept. 12, 2013), http://abcnews.go.com/US/family-sues-flags-womansfall-14-story-high/story?id=20231931 (discussing the July roller coaster death and alleged safety issues).

2. See, e.g., Tina Burgess, Water Ride Accident at Cedar Point, Six Flags Death: Too Many People?, EXAMINER.COM (July 22, 2013, 1:04 AM), http://www.examiner.com/article/water-rideaccident-at-cedar-point-six-flags-death-too-many-people-video (explaining that patrons were submerged in water after the boat overturned); Cedar Point Accident: Log Flume Ride Malfunctions, Injures 7, CHRISTIAN SCI. MONITOR (July 21, 2013), http://www.csmonitor.com/USA/Latest-NewsWires/2013/0721/Cedar-Point-accident-Log-flume-ride-malfunctions-injures-7 (noting passengers were "belted into the boat" and unable to escape).

3. See, e.g., Laura Petrecca \& Rebecca Castagna, Seeking the Thrill of Your Life - Just not your Last; Two Weekend Accidents have Theme Park Fans Asking: Are Rides Safe?, USA TODAY (McLean, Va.), July 23, 2013, at 3A (discussing cascade of media coverage for both ride accidents).

4. See, e.g., id. (providing Facebook and Twitter messages expressing flood of concerns over ride safety).

5. Top 10 Reasons to Visit Kansas City in 2014, VISIT KC (Jan. 13, 2014), http://www.visit $\mathrm{kc} . \mathrm{com} /$ press-release/top-10-reasons-visit-kansas-city-2014.

6. Tony Rizzo \& Adam Darby, Verrückt, the World's Tallest and Fastest Water Slide, is Taking Shape at Schlitterbahn (poll), KAN. CITY STAR (Nov. 19, 2013), http://www.kansascity.com/ 2013/11/19/4633721/take-a-peek-at-verruckt-the-worlds.html.
} 
next biggest, coolest thrill,", the Verrückt plunges patrons down a seventeen-story platform at speeds exceeding sixty-five miles per hour. ${ }^{8}$ With waterparks recording over 130 million visits annually, ${ }^{9}$ and constantly creating bigger and faster rides,${ }^{10}$ the recent surge of national concern over ride safety is understandable. ${ }^{11}$

But ride safety not only concerns the public. Courts now struggle to determine whether new rides promising heightened thrills require heightened liability. ${ }^{12}$ The law regarding the appropriate liability standard for water ride operation is especially fractured and unclear. ${ }^{13}$ As water rides grew in complexity, variety, and intensity, courts contorted tort liability by inconsistently applying a heightened standard of care to ride operators. ${ }^{14}$ These multiplying inconsistencies eventually

7. Id.

8. See id. (providing various ride design specifications and measurements); Steve Larese, Verruckt: Designer of Tallest Slide Takes the Plunge, USA TODAY (July 7, 2014, 9:17 AM), http://www.usatoday.com/story/travel/destinations/2014/06/26/verruckt-worlds-tallest-water-slideexclusive-ride-video/11421473/ (noting that the Verrückt "is taller than both Niagara Falls and the Statue of Liberty ... [and] promises to be a daredevil blockbuster."); Edward M. Eveld, First Riders on Verrückt at Schlitterbahn Love the 'Rush' (with video), KAN. CITY STAR (July 14, 2014), http://www.kansascity.com/entertainment/article697346.html (noting that the slide's first riders sought - and loved - the rush from plunging down a 160-foot-tall slide platform). It is also not surprising that the world's largest water slide resides in Kansas City because the Midwest is considered the largest waterpark market. See Mary Syrett \& Callina Wood, A Delicious Splash, MisSOURI LIFE (July 2, 2013), http://www.missourilife.com/travel/delicious-splash/. In fact, a different waterpark in Kansas City is the largest in the Midwest, at sixty acres. Id. And Kansas City is home to the World Waterpark Association. See World Waterpark Ass'n, Contact Us, http://www.waterparks.org/contactus.asp (last visited May 8, 2015).

9. See AECOM, The Americas Continued Growth and Economic Recovery, in 2012 THEME INDEX: GLOBAL ATTRACTIONS ATTENDANCE REP. 23 (2013), available at http://www.aecom.com/ deployedfiles/Internet/Capabilities/Economics/_documents/2012\%20Theme\%20Index\%20Combine d_1-1_online.pdf (providing annual attendance statistics for American theme parks). It is also not surprising that the Verrückt is so popular that, as of August, 2014, "demand is greater than the amount of available rides" for the water slide, which means that patrons must reserve a ride time to even get on the slide. Verrückt - World's Tallest Waterslide! SCHLITTERBAHN WATERPARK, http://www.schlitterbahn.com/kansas-city/rides/all-new-verruckt (last visited May 8, 2015).

10. See, e.g., Brian Avery \& Duncan R. Dickson, Insight into Amusement Park Ride and Device Safety in the United States, 2 Worldwide HoSPITALITY \& TOURISM THEMES 299, 300 (2010) (on file with the author) (noting that modern amusement parks swim in a constant race with each other to build "bigger, taller, and faster" rides).

11. See, e.g., Petrecca \& Castagna, supra note 3 (providing outpour of Facebook and Twitter messages expressing concerns over ride safety); Amy Hawley \& Shannon Halligan, 8-Year-Old Nearly Loses Toe at Schlitterbahn, KSHB ACTION NEWS (July 24, 2013), http://www.kshb.com/dpp/ news/local_news/woman-warns-others-about-schlitterbahn-experience (interviewing mother of injured child who posted warning about waterpark on Facebook).

12. See infra Part II.C. (discussing courts' divergent treatment of water-ride operators with respect to the applicable liability standard).

13. $I d$.

14. See Chavez v. Cedar Fair, LP, No. WD 75373, 2013 Mo. App. LEXIS 843, at *5 (Mo. Ct. App. July 16, 2013) (applying highest duty of care to ride operation), rev'd, No. SC93658, 2014 Mo. 
derailed industry-wide efforts to streamline inspection procedures, ride testing and other safety measures because different courts often imposed different requirements for different rides based on different rationales. ${ }^{15}$ So, operators ignored industry efforts to develop effective and uniform safety measures because of the frequent conflict between what the industry suggested and what courts required. ${ }^{16}$

Today, this extensive liability patchwork forms a Frankenstein's monster that destroys uniformity, eludes court control, and terrorizes both injured patrons and ride operators alike by making it impossible to predict which tort principals apply in water-ride cases. ${ }^{17}$ Absent a more uniform approach, courts risk applying overly demanding standards on the operators of low-risk rides, and lenient standards on the operators of high-risk rides. This mismatch is largely attributable to the difficulty of drawing a line between high-risk and low-risk rides. Given the infinite variety of water-ride designs, features, operation methods, and potential patrons, it is impossible for courts to consistently divide extreme rides (fit for a heightened standard) from 'not-so-dangerous' rides. ${ }^{18}$ While Universal Studios has a Harry Potter adventure where a 'sorting hat' can successfully sort patrons of all shapes and sizes into four different

LEXIS 220, at *26 (Mo. Nov. 12, 2014) ("This Court finds that the trial court erred in instructing the jury that Cedar Fair owed the highest degree of care to Ms. Chavez because the ordinary duty of care is the proper duty of care in a negligence action against an owner or operator of an amusement park."); see also Nalwa v. Cedar Fair, L.P., 290 P.3d 1158, 1160 (Cal. 2012) (applying assumption of risk doctrine to injuries from bumper cars).

15. See, e.g., Avery \& Dickson, supra note 10, at 309 (noting that "[t]here still is a large faction of fixed site, mobile operators, manufacturers, states regulators and inspectors who are simply unaware, choose to ignore, or do not have to abide by the current amusement ride and device safety standards. The inconsistent application and use of standards across the USA potentially aides in unnecessarily placing patrons in harms-way.").

16. Id.

17. See id. at 310 (explaining the effect of inconsistent liability standards and noting that "across the USA, amusement ride and device owners and operators are being subjected to varying approaches to industry safety based on state-by-state objectives and concerns. As a result, owners and operators are interpreting and applying the existing standards inconsistently. Many of the requirements to operate an amusement ride or device change based on the number of rides, employees, and/or location of the facility or temporary event. This haphazard approach does little to assist in the unification of safety efforts industry wide and potentially inhibits the closure of any gaps realized from previous incidents or situations."); William L. Prosser, Res Ipsa Loquitur in California, 37 CALIF. L. REV. 183, 186 (1949) ("The law of negligence of the late nineteenth century was to a considerable extent the law of railway accidents. It was perhaps inevitable that Baron Pollock's Latin phrase should become involved in passenger cases, and that it should there crossbreed with the carrier's burden of proof and produce a monster child.").

18. See Gomez v. Superior Court, 113 P.3d 41, 45-49 (Cal. 2005) (surveying the different factors that courts around the country inconsistently examine to determine the appropriate liability standard). 
'house' categories, that magical sorting power does not travel beyond the park gates and into the courthouse. ${ }^{19}$

Even if categorizing rides by risk is a good idea in theory, a recent Missouri case shows that, in practice, drawling lines of demarcation between rides and liability standards is unworkable. ${ }^{20}$ In Chavez $v$. Cedar Fair, the Missouri Court of Appeals held that "the facts and circumstances of a given case" determine whether an ordinary or heightened care standard applies to ride operation. ${ }^{21}$ But the court lacked a concrete test for identifying and weighing the facts and circumstances in the case. ${ }^{22}$ Consequently, the court overlooked important and unique ride characteristics, such as patron control, water speed, the slide's height, and the operator's inability to steer the raft as it traveled down the slide - all factors that affect the risk of injury and, thus, the appropriate liability standard. ${ }^{23}$

However, the Missouri Supreme Court caught the oversight, overruled the appellate court, and held that the slide operator was subject to a reasonable care standard instead of a heightened liability standard. ${ }^{24}$ The supreme court emphasized that amusement park rides were not dangerous enough to justify raising the liability standard beyond reasonable care. ${ }^{25}$ So, instead of choosing between two standards in each

19. See 'A Celebration of Harry Potter' Brings Stars, Sorting Hat, and Wizard Duels to Universal Florida, WALT DISNEY WORLD INFO. (Jan. 24, 2014), http://blog.wdwinfo.com/2014/ 01/24/a-celebration-of-harry-potter-brings-stars-sorting-hat-and-wizard-duels-to-universal-orlando/ (describing the sorting hat experience, which "allowed guests to actually be sorted into a Hogwarts house by a Hogwarts student in a sorting ceremony."). To be clear, one can purchase a sorting hat replica to take beyond the park gates, but that replica does not enable courts to effectively sort thrill rides into concrete liability categories - even if the owner is a "Gryffindor." See The Universal Store, UNIVERSAL ORLANDO RESORT, https://www.universalorlando.com/Merchandise/Gift/ Harry_Potter/Hats/Sorting_Hat.html (last visited May 8, 2015) (selling sorting hat replicas for \$29.95).

20. See, e.g., Chavez v. Cedar Fair, LP, No. WD 75373, 2013 Mo. App. LEXIS 843, at *5 (Mo. Ct. App. July 16, 2013), cert granted (reviewing application of highest degree of care duty to water-ride operators) rev'd, No. SC93658, 2014 Mo. LEXIS 220, at *26 (Mo. Nov. 12, 2014).

21. Id. at $* 13$.

22. See id. (explaining that the standard of care depends on the circumstances).

23. See id. at *1-3, 19-20 (showing that the injured patron was not in an enclosed vehicle, was not restrained by any belt or harness, and the patron shared control over the raft and risk of injury because releasing her grip on the raft's straps or uncrossing her legs during the ride enabled ejection or collision with co-patrons).

24. See Chavez v. Cedar Fair, LP, No. SC93658, 2014 Mo. LEXIS 220, at *26 (Mo. Nov. 12, 2014) ("This Court finds that the trial court erred in instructing the jury that Cedar Fair owed the highest degree of care to Ms. Chavez because the ordinary duty of care is the proper duty of care in a negligence action against an owner or operator of an amusement park."). The Missouri Supreme Court's decision in Chavez was released during the editing phase for this Comment. So, this Comment only provides a light analysis of that recent decision.

25. See id. at *3-5. 
new case involving a thrill-ride injury, Missouri courts have a single liability standard that offers increased predictability for both parties. ${ }^{26}$

In addition to providing predictability, the reasonable care standard also prevents prejudice. With a heightened standard, the jury instructions "overemphasize[] the defendant's duty" 27 by requiring precautions beyond what is reasonable. ${ }^{28}$ As reasonable care requires operators to take a level of precaution that matches the level of risk (the higher the risk, the higher the precaution), the heightened standard effectively requires operators to take more precaution without knowing when more is enough. ${ }^{29}$ Further, the heightened standard waters down comparative fault and contributory negligence defenses by implicitly suggesting to jurors that the operator's duty of extreme care dwarfs the patron's lesser duty to exercise reasonable care. ${ }^{30}$ Thus, due to the semantic differences between these two standards, juries are more likely to find in favor of careless patrons and against careful operators. ${ }^{31}$

However, while the reasonable care standard promotes uniformity, predictability, and fairness, those benefits flow chiefly to water-ride operators. For patrons, there remain challenges with identifying an injury's cause and with the lack of control on certain water rides.

To balance operators' need for predictability with patrons' need for protection, this Comment proposes that courts should apply the reasonable care standard with a rebuttable presumption of operator negligence. By making reasonable care the default liability standard, courts can replace confusion with clarity because the liability standard does not change based on a court's particular view of the ride, features, patrons, and risks. Instead, courts will have a baseline, reasonable care

26. See id. at *4-5.

27. Id. at $* 17$ (quoting Gormowsky v. Ingersol, 241 S.W.2d 60, 62 (Mo. Ct. App. 1951)).

28. See Ronald J. Cereola \& Reginald Foucar-Szocki, Fixed Site Amusement Rides: Who Regulates Safety?, 25 FLA. INT'L U. HospitAlity REV. 45, 49 (2007), available at http:// digitalcommons.fiu.edu/hospitalityreview/vol25/iss2/4 ("[A] charge by the Court to the jury, directing a heightened standard of care, may very well sway the jury in favor of the plaintiff . ...”).

29. See William E. Westerbeke, Kansas Survey: Torts, 33 U. KAN. L. REV. 1, 14 n.75 (1984) (explaining that juries are likely to misunderstand the highest degree of care instruction as requiring liability regardless of fault because the standard demands precautions that exceed reasonableness); Chavez, 2014 Mo. LEXIS 220, at *17 (internal quotation omitted) (noting that reasonable care offers flexibility and increased precaution against increased risks, while the heightened liability standard "overemphasizes the defendant's duty").

30. See, e.g., Union Traction Co. of Ind. v. Berry, 121 N.E. 655, 658 (Ind. 1919) (arguing that the "use of such terms as 'slight care,' 'great care,' 'highest degree of care,' or other like expressions in instructions . . . is misleading; and . . . constitute an invasion of the province of the jury").

31. Chavez, 2014 Mo. LEXIS 220, at *23-24 (pointing out the misleading nature of the heightened care jury instruction and finding that the ride operator was prejudiced at trial by an elevated liability instruction). 
standard that provides both predictability and flexibility by always requiring ride operators to exercise precautions that are proportionate to the risk of harm from the specific ride. ${ }^{32}$

In contrast, the rebuttable presumption places the initial burden of proof on the ride operator to first explain the cause of the accident at issue, and then to show that the operator exercised reasonable care. ${ }^{33}$ This approach strikes at the heart of patrons' empirical difficulty identifying the cause of an accident - a difficulty that goes up whenever a patron goes plummeting down, around, or upside down on a water ride. While it may seem that patrons should be able to connect their injuries to some type of event - such as smashing into another patron or a ride's fiberglass chute - the more important issue is the cause of that impactful event. But patrons are in the worst position to answer that question because patrons often lack the ability or opportunity to analyze the mechanics of a ride while lying on their backs and being whisked away by massive volumes of water that launch patrons at high speeds through vertical loops, sideway turns, and spinning whirlpools.

Contrast patrons' situation with the ride operators' standpoint. Operators not only have a big-picture view of the ride, operators are also the most likely to be familiar with a ride's common problems, design, injury risks, and ride components that may have contributed to a patron's particular injury. Be it a sharp turn on a water slide or water pump that gushes too much water into a water channel, it is the ride operator-often an eyewitness to an accident-who is in the best position to provide evidence and an explanation about the cause of a patron's injury. ${ }^{34}$ Given the operator's superior position, it makes more sense to apply a rebuttable presumption of negligence onto the operator, which shifts the initial burden of proof onto the operator to explain the cause of an accident, instead of leaving the injured patron to speculate about the cause of the accident.

Further, the rebuttable presumption addresses the control disparity between patrons and operators. While many water rides provide patrons with significant freedom and control, patrons are still dependent on ride

32. See infra part II.B. (discussing flexible nature of the reasonable care standard in requiring precaution commensurate with risks).

33. See infra part III.C. (arguing that the combination of a rebuttable presumption and reasonable care standard is important for clear jury instructions that also balance inherent ride risks with appropriate precautions).

34. See O'Callaghan v. Dellwood Park Co., 89 N.E. 1005, 1007 (Ill. 1909) ("If the injury of a passenger is caused by apparatus wholly under the control of a carrier and furnished and managed by it, and the accident is of such a character that it would not ordinarily occur if due care is used, the law raises a presumption of negligence."). 
operators to perform inspections, maintenance, and other similar functions. In fact, the original goal of the heightened liability standard was to place the risk of loss onto operators because, by surrendering control and the ability to protect against various dangers, patrons depended on operators for safety. ${ }^{35}$ Yet heightened liability rarely achieves that protective goal because patrons - unfamiliar with ride mechanics and engineering - struggle to explain the cause of ride injuries. But the rebuttable presumption fills this causation gap and, as a result, fulfills the fundamental protective goal of the heightened standard by requiring an operator to show that a patron's injury was not caused by the operator's negligence. ${ }^{36}$ While shifting the burden to the operator may seem unfair, the combination of a rebuttable presumption with a reasonable care standard reduces potential prejudice against the operator by applying a balanced, flexible test that aligns the level of required precaution with the level of foreseeable risk of injury.

In addition, while the rebuttable presumption primarily benefits patrons, the presumption still produces fair results for operators by preserving conduct-based defenses. For example, where patrons are careless or willfully engage in dangerous conduct, operators can call upon the full force of a contributory negligence or an assumption of risk defense. Operators can rely on these defenses without worrying that ambiguous jury instructions may confuse jurors with multiple liability standards - a critical benefit that vanishes under a heightened standard. ${ }^{37}$ Furthermore, an assumption of risk defense is especially important with water rides because patrons go to waterparks for the purpose of chasing thrills and experiencing a sense of danger. ${ }^{38}$ While patrons do not seek actual harm, injury can easily result from patrons' careless actions, violation of warnings and ride rules, or from horseplay near park

35. See, e.g., Brown v. Winnwood Amusement Co., 34 S.W.2d 149, 152 (Mo. Ct. App. 1931) (connecting heightened liability standard with common carriers' exclusive control and management of the apparatus).

36. See id.

37. See infra part III.C. (arguing that the combination of a rebuttable presumption and reasonable care standard is important for clear jury instructions that also balance inherent ride risks with appropriate precautions).

38. See Lamb v. B \& B Amusements Corp., 869 P.2d 926, 931 (Utah 1993) (explaining that, unlike passengers on early common carriers, amusement ride patrons "expect ... high speeds, steep drops, and tight turns."); Jeffrey S. Goodfried, Comment, Back on Track: How the California Supreme Court Got It Wrong, and What Legislature Can Do to Fix It, 27 LOY. L.A. ENT. L. REV. 1, 11 (2007) ("[T]he purpose of thrill rides is to frighten and surprise the rider by utilizing means that present the impression of inherent danger. Dangerous elements are intrinsic to these rides, and passengers choose these rides for exactly this reason."). 
machinery. ${ }^{39}$ Under a heightened standard, a ride operator is still likely to be responsible for these avoidable, self-inflicted harms. But a rebuttable presumption makes it easier for courts to weed out cases where the patron bears the blame, which provides a larger benefit of encouraging more responsible patron behavior. ${ }^{40}$

Part II.A. of this Comment will provide background information about the evolution of both water rides and heightened liability standards. Part II.B. will examine the differences and similarities between the heightened common carrier standard and the reasonable care standard. Part III will then analyze the benefits of applying a reasonable care standard over other negligence standards. Then, Part III will explain the important balancing role that a rebuttable presumption provides in water-ride cases. Part IV will conclude that courts should apply a reasonable care standard with a rebuttable presumption of negligence as the default approach for water-ride injury claims.

\section{BACKGROUND}

\section{A. Charting a Historical Course of the Changes, Currents, and Cascades in Common Carrier Liability}

To analyze whether water-ride operators should be subject to the heightened, common carrier standard or, instead, a reasonable care standard with a rebuttable presumption, it is important to understand the genesis and evolution of common carrier liability, water rides, and the courts' treatment of ride operators. While modern courts rely heavily upon early court rationales, technological advances raise new issues and concerns that early courts and ride operators did not anticipate. To reconcile these early court rationales with present conditions, this section will discuss the unique and historical concerns first raised by early courts in common-carrier cases and then in water-ride cases. This section concludes by examining the various ways that courts have either divorced or combined water-ride operation and common carrier liability. Each section covers similar spans of time, but given the way that modern courts are divided over different issues and concerns, it is more helpful to

39. See, e.g., Desai v. Silver Dollar City, 229 Ga. App. 160, 160-63 (Ga. Ct. App. 1997) (granting summary judgment against patron who jumped out of a raft despite receiving multiple warnings not to do so).

40. See infra part III.C. (arguing that the rebuttable presumption and reasonable care combination strike a delicate balance between inherent risks and appropriate caution). 
organize the background by individual issues instead of by set periods of time.

\section{Common Carrier Genesis}

Originally, a "common carrier" was someone who transported goods for a cost. ${ }^{41}$ In 1680 , common law courts held these carriers strictly liable for any loss or damage to transported goods. ${ }^{42}$ So, if a carrier was extremely cautious or absurdly reckless, the carrier was still "liable for every accident, except by the act of God, or the King's enemies."43 This strict liability approach was an extension of the common-law bailment jurisprudence, where courts treated bailees-those entrusted with property of another - as insurers of entrusted goods against any loss or damage. ${ }^{44}$

Economic and public policy concerns prompted early courts to extend the role of insurer to common carriers. ${ }^{45}$ Courts feared that a due care standard would allow carriers to excuse their lack of precaution by blaming some unknown third party for damage to transported goods. ${ }^{46}$ Courts rationalized that strict liability ensured that carriers would exercise "greater care and diligence" 47 because carriers would bear the full cost for lost or damaged goods. ${ }^{48}$ This outpour of extreme carrier caution would theoretically reduce the risk of loss and inspire public

41. See Gomez v. Superior Court, 113 P.3d 41, 43 (Cal. 2005) (noting carriers of property for reward were labeled "common carriers" (citing Lovett v. Hobbs, 89 Eng. Rep. 836 (1680))). While over three-hundred years have passed since common-law courts created the definition, the legal meaning has remained essentially the same, as a common carrier is still considered to be "a commercial enterprise that holds itself out to the public as offering to transport freight or passengers for a fee." BLACK's LAW DiCTIONARY 226 (8th ed. 2004).

42. See Gomez, 113 P.3d at 43 (articulating that "[c]arriers of goods are bailees" and strictly liable for damage to bailed goods at common law); See also G. Gregg Webb, Note, The Law of Falling Objects: Byrne v. Boadle and the Birth of Res Ipsa Loquitur, 59 STAN. L. REV. 1065, 1081, 1085 (2007) (noting existence of strict liability standard for damage or loss of property); Robert J. Kaczorowski, The Common-Law Background of Nineteenth-Century Tort Law, 51 OHIO ST. L.J. 1127, 1132-35 (1990) (noting gratuitous bailors only required to exercise slight care, but common carriers were strictly liable).

43. Kaczorowski, supra note 42, at 1135 (quoting Forward v. Pittard, 99 E.R. 953, 953 (Crt. Of King's Bench, 1 TERM REPORTS 27, 1785)).

44. See id. at 1129-31 (tracing the origin of common carrier liability to common-law bailment concepts); Gomez, 113 P.3d at 43 (explaining that first common carriers were labeled as bailees).

45. See Kaczorowski, supra note 42, at 1135-36 (discussing various policy goals of applying a strict liability standard over a due care standard).

46. See id. at 1136, 1139 (pointing to common carriers' attempts to escape liability based on third-party negligence).

47. Id. at 1136 .

48. See id. (examining goal to prevent excuses and encourage greater care as a justification to apply strict liability to common carriers). 
confidence in carrier services. ${ }^{49}$ The public's reduced loss, courts argued, would precipitate a flood of public confidence in carrier services and, as a result, benefit carriers through increased popularity and a cascade of new business. ${ }^{50}$

\section{Creation of the Heightened Standard of Care}

The heightened standard of care emerged in the late 1700s when common carriers began to transport passengers in stagecoaches. ${ }^{51}$ Common-law courts explained that, unlike inanimate goods, passengers could perceive potential danger and either avoid or mitigate incoming harm. ${ }^{52}$ But strict liability did not incentivize passenger caution because carriers were still liable for injuries that passengers could easily prevent. $^{53}$ At the same time, passengers had a limited ability to avoid harm because carriers had "exclusive control" over the vehicle. ${ }^{54}$ Passengers were helpless if a carrier operator overturned the stagecoach ${ }^{55}$ or failed to inspect defective mechanical components. ${ }^{56}$ Courts thus feared that the reasonable care standard - a concept still developing in the $1700 \mathrm{~s}^{57}$-was an "insufficient incentive to deter carriers from

49. Id.

50. See id. ("[C]ommercial interests also motivated English judges to increase common carrier liability").

51. See Gomez v. Superior Court, 113 P.3d 41, 43 (Cal. 2005) (identifying stagecoach operators as the first carriers that were not held strictly liable for passenger injuries (citing Lovett v. Hobbs, 89 Eng. Rep. 836 (1680))); Webb, supra note 42, at 1088 (pointing out that common carrier liability was founded by common-law treatment of passengers injured on stagecoaches, but railroads molded the majority of the common-law tort concepts applied to common carriers).

52. See Webb, supra note 42, at 1085 (noting "people could both watch out for their own safety and precipitate their own injuries.").

53. See id. (discussing passenger ability to avoid harm and mitigate injuries).

54. See Kaczorowski, supra note 42, at 1158 (noting that passengers were helpless and unable to anticipate or prevent accidents while being transported by a carrier).

55. See, e.g., St. Louis Sw. Ry. Co. v. Parks, 76 S.W. 740, 742 (Tex. 1903) (explaining that passengers on railroad trains cannot stop a train from derailing, and it makes sense to presume the operator of that train was negligent in causing the accident).

56. See Webb, supra note 42, at 1085-86 (noting that stagecoach passengers had no way to determine if transportation machinery was sound and that only the carrier could find defects by inspecting the stagecoach (citing Christie v. Griggs, (1809) 170 Eng. Rep. 1088 (P.C.)); Johns Hopkins Hosp. v. Correia, 921 A.2d 837, 846 (Md. Ct. Spec. App. 2007) (explaining that "when the passenger commits himself to the carrier he does so in ignorance of the machinery and appliances (as well as their defects) used in connection with the means of transportation, and becomes a passive and helpless creature in the hands of the transportation company and its agents" (quoting Fox v. Philadelphia, 57 A. 356, 358 (Pa. 1904)), aff'd, 954 A.2d 1073 (Md. 2008))).

57. See Webb, supra note 42, at 1085 n.116 (citation omitted) ("The concept of 'reasonable care' as the basis for negligence liability was just coming into widespread use in the common law during this period. The meaning of 'negligence' was thus in flux and not always pegged to a reasonable care standard."). 
compromising passenger safety." 58 To balance these passenger and carrier concerns, common-law courts created a heightened liability standard that was intended to be "below strict liability but above... reasonable care." 59 Though a creative attempt to craft a middle ground, courts struggled to apply the standard because there was no uniform definition or test to determine if a carrier satisfied the heightened standard. ${ }^{60}$

American courts also struggled to navigate the heightened liability standard. ${ }^{61}$ In the 1839 case of Stokes v. Saltonstall, the Supreme Court adopted the heightened standard, holding that carriers must exercise "the utmost prudence and caution." 62 But the Court did not clarify the difference between "normal" prudence and the "utmost" prudence. ${ }^{63}$ Further, while the Court noted that common carriers were not insurers of passengers' safety, a constant shower of confusing and conflicting interpretations of the same standard effectively obscured the precise scope and limits of the carriers' duty. ${ }^{64}$

As time went on, courts only deepened the pool of confusion by adding more semantic variations of the standard in an attempt to clarify the scope of liability. For example, one court stated that carriers "must exercise the highest degree of care and caution for the safety of [their] passengers, and do all that human foresight can reasonably require,

58. Id. at 1085 .

59. Id. (discussing the middle ground between strict liability and reasonable care).

60. See, e.g., Benjamin C. Zipursky, Sleight of Hand, 48 WM. \& MARY L. ReV. 1999, 2019-21 (2007) (noting that, at common law, common carriers were held to a heightened standard of care that was only defined as being more demanding than the ordinary care standard); Philip H. Budwick, Strict Liability or Negligence: What Standard of Care Applies When Crewmembers Assault Passengers on Cruise Ships?, 19 TUL. MAR. L.J. 353, 355 (1995) (explaining that common law "required carriers to do everything possible to provide for the safe transportation of passengers" while the requirement was not intended to make carriers strictly liable for injuries to passengers); Union Traction Co. of Ind. v. Berry, 121 N.E. 655, 658 (Ind. 1919) (explaining that the heightened standard was not measurable because it required some unknown level of care that flowed beyond reasonable care).

61. See William E. Westerbeke \& Stephen R. McAllister, Survey of Kansas Tort Law: Part I, 49 U. KAN. L. REV. 1037, 1065 (2001) (explaining that phrases like "the highest degree of care" are frequently applied but rarely defined with a measurable test).

62. Gomez v. Superior Court, 113 P.3d 41, 43 (Cal. 2005) (citing Stokes v. Saltonstall, 38 U.S. 181, 193 (1839)), aff'g 1 Cal. Rptr. 3d 860 (Cal. Ct. App. 2003).

63. See id. (citing Stokes, 38 U.S. at 193) (providing a mere semantic difference between the utmost care and reasonable care).

64. See Stokes, 38 U.S. at 191-92 (finding common carrier not strictly liable for passenger injured in stagecoach); Gomez, 113 P.3d at 44-46 (quoting Lopez v. S. Cal. Rapid Transit Dist., 710 P.2d 907 (Cal. 1985)). 
consistent with ... practical operation, to prevent accidents ....,65 Other courts described the heightened standard as requiring the "utmost care" or "the greatest possible care and diligence." these definitional variations suggested something more than reasonable care, ${ }^{67}$ courts remained confused over the precise scope of a carrier's duty under the heightened standard.

Due to this unsettled scope, the heightened standard precipitated inconsistent outcomes when courts applied it to similar facts. ${ }^{68}$ Some courts held carriers liable for all vehicle defects, "no matter how extraordinary the inspection required to discover" the defect; ${ }^{69}$ other courts only held carriers liable for outward, visible defects. ${ }^{70}$ Some courts instructed juries that carriers were liable for "the smallest negligence"; ${ }^{71}$ other courts instructed juries that carriers had to do everything "humanly possible" to prevent injury to passengers. ${ }^{72}$

It is no surprise that these different interpretations produced different jury verdicts in cases with similar facts. For example, in two cases where passengers were injured after an axle fell out from a stagecoach, one jury found for the carrier, and the other jury found for the passenger. ${ }^{73}$ Both carriers failed to discover a crack in their axles. ${ }^{74}$ In finding for the carrier, one jury explained that no matter the type of inspection, the operator could not have detected the defect beforehand. ${ }^{75}$ In finding for the passenger, the other jury noted that axle defects, though

65. Bibeau v. Fred W. Pearce Corp., 217 N.W. 374, 376 (Minn. 1928) (citing O'Callaghan v. Dellwood Park Co., 89 N.E. 1005 (Ill. 1909)).

66. Chavez v. Cedar Fair, LP, No. WD 75373, 2013 Mo. App. LEXIS 843 at*10-11 (Mo. Ct. App. July 16, 2013) (citing Gromowsky v. Ingersol, 241 S.W.2d 60, 63 (Mo. Ct. App. 1951)), rev'd, 450 S.W.3d 291 (Mo. 2014).

67. Rivere v. Thunderbird, Inc., 353 So. 2d 346, 348 (La. Ct. App. 1977) (citing Givens v. De Soto Bldg. Co., 100 So. 534 (1924)).

68. See Gomez, 113 P.3d at 43-46 (illustrating the different outcomes when state courts applied the heightened standard to similar thrill-ride cases).

69. Kaczorowski, supra note 42, at 1162.

70. See Webb, supra note 42 , at 1087 (discussing case where the jury limited liability to discoverable defects).

71. See Kaczorowski, supra note 42, at 1158-59 (quoting Aston v. Heaven, (1797) 170 Eng. Rep. 445 (K.B.); 2 Esp. 533, 535).

72. See id. at 1168 ("[T]he determination whether the precautions taken by carriers had met this abstract standard in the circumstances of specific cases was made by juries. ...").

73. See id. at 1163-65 (demonstrating inconsistent results under common carrier standard as applied to similar facts).

74. See id. (explaining that both axles slipped from the stagecoach because an undiscovered crack caused the wood to split and separate).

75. See id. at 1163 (citing Christie v. Griggs, (1809) 170 Eng. Rep. 1088 (P.C.); 2 Camp. 79) (discussing defense verdict in early heightened duty, common carrier case where "[t]he jury found ... the weakness in the axle-tree was not discoverable by inspection of any kind"). 
hidden, were not "impossible to guard against.", As time went on, juries continued to pour out inconsistent outcomes, and courts diluted the heightened standard's purpose with a wave of conflicting caselaw.

3. Splashes and Spillover between the Heightened Standard and a Rebuttable Presumption of Negligence

Several early courts interpreted the heightened standard as applying a presumption that the carrier was liable for the passenger's injury. ${ }^{77}$ However, this presumption of negligence was an independent tort doctrine that was distinct from the heightened liability standard. But courts, confused over the heightened standard's meaning and effect, assumed that the heightened standard implied a presumption that carriers were at fault. ${ }^{78}$ This presumption shifted the burden of proof to the carrier. $^{79}$ To rebut the presumption of negligence, the carrier had to both explain the cause of the accident ${ }^{80}$ and also provide evidence that the carrier's precautions satisfied the heightened standard of care. ${ }^{81}$ Over time, as common carriers changed from stagecoaches to railroads, ${ }^{82}$ the combination of the heightened liability standard and the rebuttable presumption-sometimes labeled res ipsa loquitur ${ }^{83}$-gained wide acceptance in American courts. ${ }^{84}$

76. See id. at 1164-65 ("[T]o escape liability, the carrier then had to show that the injury was unforeseeable or impossible to guard against.").

77. See Webb, supra note 42, at 1085-87 (citing Christie, 170 Eng. Rep. 1088, as the first case to combine the heightened liability standard with a presumption of carrier negligence).

78. See id. at 1090 (explaining heightened standard of liability for common carriers and res ipsa loquitur were created and applied simultaneously).

79. See Kaczorowski, supra note 42 , at 1163 (describing change in allocation of burden of proof "on the basis of the public policy of promoting public safety by requiring parties to behave with due care" in order to "impos[e] liability on the party in the best position to avoid the injury and ... requir[e] a party to compensate for injuries caused by his fault").

80. See id. at 1164-65 (explaining that carriers met utmost degree of care standard by showing passenger's injury was unforeseeable or impossible to prevent).

81. See Webb, supra note 42, at 1086 (requiring evidence both of the cause of the stagecoach accident as well as evidence that the operator exercised the "utmost care" (citing Christie, 170 Eng. Rep. 1088 (C.P. 1809))).

82. See, e.g., Brown v. Winnwood Amusement Co., 34 S.W.2d 149, 152 (Mo. Ct. App. 1931) (holding res ipsa applied to common carriers due to carriers exclusive control and management of apparatus), overruled by Chavez v. Cedar Fair, LP, 450 S.W.3d 291 (Mo. 2014); Webb, supra note 42, at 1092 (noting common carrier duty toward passengers and res ipsa fault inference were both justified by a control disparity between railroad operators and passengers).

83. See id. at 1088 (discussing the "connection between common-carrier cases and the emergence of the res ipsa doctrine").

84. See, e.g., Hardin v. San Jose City Lines, Inc., 260 P.2d 63, 65 (Cal. 1953) (noting that in addition to holding common carriers to a heightened standard of care, it is "well settled ... that an inference of negligence based on res ipsa loquitur arises" where passengers are injured by a common 
To be sure, there were definite similarities between the rationales for applying a rebuttable presumption of carrier negligence and the justifications for creating the heightened standard of care. For example, both concepts originated from concerns that a carrier's exclusive control over a vehicle ${ }^{85}$ made passengers' safety dependent on the carrier's expertise and skill. ${ }^{86}$ Courts argued that the carrier's exclusive control placed the carrier in the best position to prevent harm. ${ }^{87}$

Further, courts argued that passengers could not prevent serious injury due to a lack of specialized mechanical training. Most passengers had no idea if a train or stagecoach was properly maintained, and passengers were unlikely to detect an operator's lack of skill or training before the operator's mistake injured the passengers. ${ }^{88}$ With an inference of negligence, courts could balance that knowledge gap and encourage cautious operation by placing a higher risk of liability on the carrier. ${ }^{89}$ At the same time, the rebuttable presumption was not supposed to make carriers strictly liable whenever someone was in an accident or injured, as the presumption's core purpose related to causation instead of liability. ${ }^{90}$

carrier's operation); O'Callaghan v. Dellwood Park Co., 89 N.E. 1005, 1007 (Ill. 1909) (applying inference of negligence to common carrier accident on roller coaster); Webb, supra note 42, at 1085-88, 1099, 1104 (identifying the simultaneous, linked evolution of the common carrier liability standard and a presumption of negligence by operators of common carriers).

85. See, e.g., Brown, 34 S.W.2d at 152-53 (holding that res ipsa applied to common carriers due to carriers exclusive control and management of apparatus); Webb, supra note 42, at 1099 (noting courts felt the "discrepancy in the relative control of plaintiff and defendant over a dangerous situation" justified a presumption that the carrier was negligent).

86. See, e.g., Johns Hopkins Hosp. v. Correia, 921 A.2d 837, 846 (Md. Ct. Spec. App. 2007) (explaining that "when the passenger commits himself to the carrier he does so in ignorance of the machinery and appliances (as well as their defects) used in connection with the means of transportation, and becomes a passive and helpless creature in the hands of the transportation company ...." (quoting Fox v. Philadelphia, 57 A. 356, 358 (Pa. 1904))); Webb, supra note 42, at 1086 (pointing out that passengers on early common carriers had "no ability to judge either the soundness of a coach or the skills of its driver and consequently had been dependent on the expertise of the defendant and his employees.... [A] rebuttable presumption of negligence should fall on the better informed"); Kaczorowski, supra note 42, at 1158 (reciting courts' concern that passengers were helpless and unable to anticipate or prevent accidents while being transported by a carrier).

87. See Jeffrey P. Aiken, Construction Experts and Res Ipsa Loquitor: Bridging the Evidentiary Gap, 30 CONSTR. LAW. 22, 25 (2010) (explaining that the foundational justification for presuming negligence is the "exclusive management and control of an instrumentality" (citing Zukowsky v. Brown, 488 P.2d 269, 276-78 (Wash. 1971))); O'Callaghan, 89 N.E. at 1007 (focusing on the operator's exclusive control and management).

88. See Kaczorowski, supra note 42 , at 1158 (noting passengers were helpless and unable to anticipate or prevent accidents while being transported by a carrier).

89. See Webb, supra note 42, at 1093 (explaining that the carrier was better informed than the passenger and would thus bear the risk of liability).

90. See id. at 1092-93 (noting that the carrier was supposed to be able to rebut the presumption and not be held strictly liable for risks that a passenger could avoid). 
The rebuttable presumption's core focus was on the evidence gap between carriers and passengers. ${ }^{91}$ Passengers on carriers were usually confined and unable to see or understand the cause of an accident. ${ }^{92}$ Carriers, by inspecting, maintaining, controlling, and operating the vehicle, had the best access to evidence of the accident's cause; but carriers had no incentive to provide that evidence to patrons. ${ }^{93}$ Without this causation evidence, a passenger could not recover for injuries from, for example, flying out of a train window right before the train derailed. ${ }^{94}$ Courts thus applied the rebuttable presumption to flush out causation evidence and protect passengers in cases where the only evidence of negligence was the accident's occurrence. ${ }^{95}$

Furthermore, courts argued that in cases where passengers were responsible for their own injuries, carriers should have little difficulty with providing clear, exonerating evidence of passenger misbehavior. ${ }^{96}$ In retrospect, the rebuttable presumption could have resolved these evidentiary access concerns without pouring the heightened standard into

91. See Aiken, supra note 87, at 25 (explaining that the presumption of negligence had an evidentiary focus instead of being a liability standard).

92. See, e.g., Parke G. Young, Recent Decision, Negligence: Res Ipsa Loquitor: Common Carriers, 18 MARQ. L. REV. 4, 265-66 (1934) (describing how "it would be difficult for him to know definitely what the carrier's employees had failed to do or to discover what they had done improperly. This is particularly true in collision cases... . The carrier is expected to explain how the collision occured [sic] because his employees have been in a better position than the plaintiff to have seen what happened.").

93. See id. (explaining that the carrier had employees to identify problems and causes that would be unknown to passengers); St. Louis Sw. Ry. Co. v. Parks, 76 S.W. 740, 742 (Tex. 1903) (explaining that passengers on railroad trains cannot stop a train from derailing, and it therefore is sensible to presume that the operator of the train was negligent in causing the accident); Jamey B. Johnson, Note, Torts - Res Ipsa Loquitor is Inapplicable When a Plaintiff Offers Expert Testimony to Furnish a Complete Explanation of the Specific Cause of an Accident, 25 U. BALT. L. REV. 261, 262 (1996) ("wrongly injured plaintiffs had no way to recover if the evidence establishing the injury was solely in the hands of the defendant." (citing Ronald J. Allen, Burdens of Proof, Uncertainty, and Ambiguity in Modern Legal Discourse, 17 HARV. J.L. \& PUB. POL'Y 627, 632 (1994))); Webb, supra note 42 , at 1086 (pointing to evidentiary access gap between passengers and carriers that justified inference of negligence to help passengers recover for their injuries).

94. See Webb, supra note 42, at 1086 (noting that passengers had only the occurrence of the accident as evidence of negligence, and despite evidence of the operator's carelessness, the passenger has no evidence about the cause of the accident).

95. For cases that illustrate how early carrier passengers faired without an inference of carrier negligence, see Benedick v. Potts, 40 A. 1067, 1068-69 (Md. 1898) (holding that the presumption did not apply where railway car passenger was found unconscious, on the side of the tracks, and unable to recall the cause of injury after the train went through a tunnel); Fisk v. Chicago Water Chute Co., 119 Ill. App. 536, 541 (Ill. App. Ct. 1905) (noting plaintiff alleging negligent operation of boat ride had the burden to provide specific evidence of negligence and could not apply res ipsa loquitor).

96. See Myrlak v. Port Auth., 723 A.2d 45, 51 (N.J. 1999) (pointing out that the defendant is only required to explain, not exonerate. Further, plaintiffs may be relieved from the burden of proof, but the burden of persuasion is unaltered by application of the presumption of negligence). 
the mix. ${ }^{97}$ But courts insisted on contorting and combining the concepts together, ${ }^{98}$ and the benefits of the presumption were rinsed away by the confusion and inconsistencies that flowed from the heightened standard's application.

\section{B. Trickles to Typhoons: From the Beginning Bubbles of Water Rides to a Modern Monsoon of Innovation.}

This section will discuss the historical evolution of amusement parks, water ride features, ride safety, and technological developments. The subsections that follow are divided by issue rather than by time. As a result, a subsection often ends by discussing modern conditions, but the next subsection begins by jumping backward in time to trace the evolution of a particular concept.

Tracing the past and present of each issue is important because, while technological advances have washed away most dangers inherent in early water rides, many modern courts overemphasize antique dangers when deciding on the appropriate liability standard for water-ride operators. $^{99}$ Thus, to determine if a heightened standard is justified for modern ride operators, it is important to examine the differences between early water rides and those that fill amusement parks today.

\section{Amusement Ride Genesis}

It made sense for early courts to classify ride operators as common carriers because transportation companies built and operated the very first American amusement parks and thrill rides. ${ }^{100}$ In the $1800 \mathrm{~s}$,

97. Compare Kahalili v. Rosecliff Realty, Inc., 141 A.2d 301, 306-07 (N.J. 1958) (applying res ipsa and reasonable care standard where plaintiff fell out of a roller coaster), with Gomez v. Superior Court, 113 P.3d 41, 47-48 (Cal. 2005) (applying heightened standard of care to an amusement park based personal injury suit).

98. See Webb, supra note 42, at 1067-68 (describing mixture of rebuttable presumption and common carrier liability)

99. See Avery \& Dickson, supra note 10, at 305 ("Restraints, emergency shutdown systems, block sensors, anti-rollbacks, machine guards, warnings, fencing, and more have become common place on most amusement rides and devices. Redundant safety systems also play a role in critical areas on amusement rides and devices.").

100. See 2 Gordon Reavley, Amusement Parks: Social History of the United States, THE 1910s, at 310 (Daniel J. Walkowitz \& Daniel E. Bender eds., 2009) (identifying the early 1800s as the time-period when the first American amusement parks were created by common carrier businesses). 
American railway, streetcar, ${ }^{101}$ train, and trolley companies-all business competitors - sought to attract customers by building small parks and primitive rides at transportation terminals throughout various cities. ${ }^{102}$ An instant success, these parks quenched Americans' thirst for a source of entertainment, relaxation, and escape from an exhausting work environment. ${ }^{103}$

Though entertaining, these early parks were more akin to picnic areas than to today's amusement parks. ${ }^{104}$ The parks were modeled after the European pleasure gardens of the late $1700 \mathrm{~s}$, which featured theatre productions, wrestling matches, concerts, fireworks, and, above all else, a large field where patrons drank beer for hours on end. ${ }^{105}$ The first rides in American parks were treated like a side activity instead of a main attraction. ${ }^{106}$ And while merry-go-rounds and carousels existed as far back as 500 A.D., the only ride found in several early parks was some type of a slide. ${ }^{107}$ Thus, in the beginning, Americans visited amusement parks to relax — not to experience death-defying thrills.

But Americans quickly turned their attention from relaxation to rides when, in the late $1800 \mathrm{~s}$, transportation companies introduced rail-based

101. See Robert Cartmell, The InCredible Scream Machine: A History of the Roller COASTER 60, 63 (1987) (crediting early American transportation companies with developing amusement parks and noting that "park owners . . . were often streetcar companies.").

102. Adam Hornbuckle \& Martin Manning, Amusement Parks and the National Parks System, in 8 AMERICAN ERAS: DEVElOPMENT OF THE INDUSTRIAl UNITED STATES 1878-1899, at 394-95 (Vincent Tompkins ed., 1997) (explaining that trolley, subway, and railway companies built parks at the end of transportation lines to attract more passengers, and, because the companies were charged a flat fee for electricity, the companies sought to soften the electric bill by attracting more riders).

103. See infra notes 112-18.

104. See infra notes 119-21.

105. Catherine C. Galley \& Briavel Holcomb, Amusement Parks, 1 ST. JAMES ENCYCLOPEDIA of Popular Culture 77, 77 (Sara Pendergast \& Tom Pendergast eds., 2000), available at http://go.galegroup.com/ps/i.do?id=GALE\%7CCX3409000080\&v=2.1\&u=ksstate_ukans\&it=r\&p= GVRL\&sw=w\&asid=dca3d92543ef633ace90550388d5c7e6 (finding terminal parks stemmed from European pleasure gardens that featured fireworks, dancing, and primitive machine-based rides. The pleasure gardens were common around large urban areas through Europe). For a more detailed explanation of the link between Europe's pleasure gardens and American amusement parks, see Dale SAmuelson \& Wendy Yegoiants, The American Amusement PARK 10-13, 16-17 (Mike Schafer ed., 2001) (tracing the evolution of flower-based pleasure gardens in France, to the British additions of theatre performances and fireworks in the mid-1600s, and finally to the United States, where Americans added stream trains, primitive Ferris wheels, and early roller coasters — rides that designers quickly designed with increases in size and speed, yet often decreases in safety).

106. Of note, Walt Disney initially designed Disneyland after this "rides-on-the-side" concept. SAMUELSON \& YEGOIANTS, supra note 105, at 11. But, after visiting the world's oldest theme park, operating in Denmark since 1583, Walt Disney quickly altered his design in order to emphasize thrill rides and create a place where Americans could marvel together over engineering masterpieces. $I d$.

107. See id. at 10 (tracing the history of carousel-type rides); CARTMELL, supra note 101, at 55 (noting that prior to 1893 , most of the early parks featured only a single slide). 
water rides and roller coasters. ${ }^{108}$ Transportation companies already built and operated rail-based transportation systems, like trains, so it was a simple task to build a similar ride based on the same mechanical concepts and designs. ${ }^{109}$ In fact, the first roller coaster was basically a glorified trolley that looped around a metal, closed-circuit track. ${ }^{110}$ Still, these primitive mechanical rides offered far more thrills than a stationary slide or rowboat. ${ }^{111}$

By 1895, engineers and architects tried to capitalize on this wave of popularity by building more complex and thrilling rides. ${ }^{112}$ For example, one of the earliest American amusement parks introduced a new type of water slide that shot riders out of a chute and over a basin of waterproviding a brief free-fall before the patron reached the water. ${ }^{113}$ By 1920, similar rides became so popular in America that, on an average summer day, over one million patrons could fill any one of the nearly 2,000 amusement parks throughout the nation. ${ }^{114}$

But the 1920s became a time of financial crisis for park owners, as Americans lost interest in amusement parks. ${ }^{115}$ With early parks located at transportation terminals, most patrons would get off a trolley or train and step right into the amusement park. ${ }^{116}$ However, the advent of the

108. See Hornbuckle \& Manning, supra note 102, at 395 (explaining that boat rides and trackbased rides on land grew out of early terminal parks). For purposes of this Comment, a "rail-based" ride is generally one that has some type of capsule that travels along a looping track. So, a rail-based ride could be a roller coaster, a train ride, or another similar ride. But a water ride, such as a tall slide, would not fit the "rail-based ride" description if patrons could control or influence their trajectory, or if patrons finished the ride by being ejected from a slide channel and into a body of water.

109. See CARTMELL, supra note 101, at 60 (explaining that many of the first park owners were rail-based transportation companies).

110. See id. at 63 (describing early roller coasters as miniature versions of trolley systems).

111. See id. at 55-56, 66 (pointing to ice slides as a stationary slide that simply provided the basis for more exciting rides like roller coasters and modern water slides); SAMUELSON \& YEGOIANTS, supra note 105, at 10 (linking Russian ice slides and the more complex designs of modern roller coasters).

112. See Galley \& Holcomb, supra note 105, at 77 (connecting "the growth of the amusement park industry" with enclosed parks "produced by architects, engineers, and planners"); REAVLEY, supra note 100, at 315 (identifying public demand for increased thrills as cause of "trend toward steeper and higher rides and greater speeds").

113. See CARTMELL, supra note 101, at 66-67. This water slide was not the only feature in this water park. In fact, Captain Paul Boyton, the first American to swim the English Channel, had "40 trained seals" throughout the park. Id. at 66. The park was appropriately named the "Sea Lion Park," and some historians even suggest that this park was America's first modern amusement park. Id.

114. See REAVLEY, supra note 100, at 312-17 (providing attendance statistics for early amusement parks and showing sharp rise in patron population).

115. See id. at 317 (contrasting early popularity boom with sudden decline in attendance).

116. See id. at 318 (describing mass transit systems as the main transportation for patrons). 
automobile changed that arrangement because Americans became independent and used their new mobility to pursue different activities, "such as motion pictures or ... independent leisure travel," instead of visiting amusement parks. ${ }^{117}$ Park operators responded by building more extreme, complex rides, ${ }^{118}$ such as roller coasters with higher speeds and steeper drops than ever before. ${ }^{119}$

Park owners started to win back American patrons, but maintaining the patrons' interest required constant development and construction of new rides with even greater thrills. ${ }^{120}$ Americans were going to spend money on the most entertaining activity available, so amusement parks had to compete against other parks as well as other forms of entertainment. ${ }^{121}$ As a result, amusement parks were locked into a constant race to see who could build the biggest, fastest, and most extreme ride in the least amount of time. ${ }^{122}$

\section{Water-Ride Characteristics and Patron Control}

Early on, patrons had little control over their movement and speed because water rides were tethered to rails and tracks. ${ }^{123}$ Yet scant control, slow speeds, and simplistic designs did not prevent water rides from becoming wildly popular in early amusement parks. ${ }^{124}$ Patrons paid good money just to sit passively in a boat that traveled on a track. For

117. Galley \& Holcomb, supra note 105 , at 79.

118. See Avery \& Dickson, supra note 10, at 299-300 (explaining that ride operators regained popularity by offering increased thrills and more extreme ride features); REAVLEY, supra note 100 , at 315 (examining how "patrons ... demanded more precipitous descents, faster rides, and greater capacity").

119. See Avery \& Dickson, supra note 10, at 300 (noting that roller coasters were fundamental in attracting patrons back to amusement parks).

120. See id. at 299-300 (pointing out that "[t]he addition of thrill rides, attractions, shows, and much more forever changed the landscape of the amusement industry and the expectations of patrons seeking new and evolving thrills"); REAVLEY, supra note 100, at 315 (demonstrating that patron demands created a trend of designing more extreme rides).

121. See Avery \& Dickson, supra note 10, at 300,312. See also Hornbuckle \& Manning, supra note 102, at 395 (explaining that the public attraction to thrill rides was because "Americans want either to be thrilled or amused, and . . are ready to pay well for either sensation.").

122. See Avery \& Dickson, supra note 10, at 299-301 (contending that "[t]he amusement park industry has been in perpetual evolution since its inception; mainly resulting from its quest to adapt to new and emerging trends and technologies in pursuit of attracting and sustaining crowds.").

123. See A Drop in the Ocean, NAT'L FAIRGROUnd ARChIVE (2007), http://www.nfa. dept.shef.ac.uk/history/miscellaneous_articles/article20.html ("These rides worked with a boat-style passenger device hoisted up an inclined track and then released and guided down the track with the aid of braking and steering assistant. . . Circular track based Water Chutes were pioneered in the 1930s").

124. See id. (indicating that water rides were quickly installed in parks after gaining strong popularity with patrons). 
example, the first water rides simply featured a mechanical pulley that hoisted a boat up an incline track before releasing the boat down a channel that emptied into a body of water. ${ }^{125}$ In the 1930 s, ride designers created water rides with looping tracks, which enabled operators to send patrons around a continuous circuit without having to retrieve boats from the bottom of the ride. ${ }^{126}$

In the $1980 \mathrm{~s}$, water rides transitioned from slow and simple to fastpaced and mechanically complex. ${ }^{127}$ For example, water rides incorporated steep drops, sharp turns, and high volumes of rapidly flowing water that pushed rafts and patrons through large channels. ${ }^{128}$ And while early rides sent boats around a flat track, newer rides sent patrons vertically through twisting tunnels, large loops, and swirling streams. ${ }^{129}$ These new features became so popular that, for the first time, water slides became regular features at amusement parks. ${ }^{130}$

The biggest effect of these new features was to decrease operators' control, and provide the patrons themselves with a greater level of control and freedom of movement. ${ }^{131}$ For example, unlike roller coasters, patrons on water slides and raft rides were not strapped into a vehicle that was anchored to a rail or track. ${ }^{132}$ Patrons could control their

125. See id. (illustrating how early water "rides worked with a boat-style passenger device hoisted up an inclined track and then released and guided down the track with the aid of braking and steering assistant. The passengers were plunged into a large pool of water and the boat left to float before being re-hoisted up the incline.").

126. See id. (detailing that "[c]ircular track-based Water Chutes were pioneered in the 1930s, with... [a] track-based Water Chute... which 'splashed' through a shallow pool and moved through a continuous circuit.").

127. See id. ("As white-knuckle demands began to dictate the structure and topology of these rides, there was a move towards more enclosed track layouts utilising [sic] steeper drops and innovations such as turntables.").

128. See id. (stating that rides in the late 1980s employed "a raging channel of water carrying a swirling circular raft of passengers through a series of twists, turns and" other ride features that were all enhanced by technological advances).

129. Joanne Austin, Blood Sport: Revisiting Traction . . . Er, Action, Park, WeIRD N.J., http://weirdnj.com/stories/action-park/ (last visited May 8, 2015) (describing a variety of rides that looped patrons through enclosed slides and offered sharper twists on non-looping slides).

130. See id. (suggesting that water slides became mainstream because patrons inundated amusement parks just to ride on certain slides).

131. See id. (revealing that what made water rides "different from other amusement parks was the control that patrons had over their ride experience").

132. Allison Becker, Blood Sport: Revisiting Traction ... Er, Action, Park, WeIRD N.J., http://weirdnj.com/stories/action-park/ (last visited May 8, 2015) (providing a first-hand description of a popular water slide from the 1980s where "a physics-defying ride ... was a cluster of four or five short, fast water slides that ended by shooting you out into a lake. Various kids would fly out at various times .... One of these vigorous 'shoots' was particularly intriguing, as it would suck you in and then immediately make an abrupt 90 degree turn. Not a 45 degree turn. Not even a nice, slow, smooth, curvy 90 degree turn. No. It would literally slam you into a wall and toss you in a different direction"). 
own movements in rapid-water kayak rides; ${ }^{133}$ their speed in bumper boats that could zoom around at 40 miles per hour; ${ }^{134}$ and their bodily position while on raft rides and water slides. ${ }^{135}$ To be sure, patrons did not have absolute control while on these water rides, but the 1980s marked the birth of a spectrum of rides and features that afforded patrons varying levels of control-a significant change from the early trackbased rides. ${ }^{136}$

Since the 1980s, water rides have constantly grown in number, features, size, and design because of amusement parks' efforts to create one-of-a-kind rides. ${ }^{137}$ As a result, water rides of the same "type" often have unique features and significantly different designs. ${ }^{138}$ Take waterrapid rides for example. One rapids ride might have an inflatable, circular raft that spins around as patrons brace themselves by gripping handles inside the raft. ${ }^{139}$ Another rapids ride might have a flat course with geysers that bounce patrons around as they sit inside a rubber raft that has seatbelts and a steering wheel - a raft feature that gives patrons control over the speed and frequency of spins. ${ }^{140}$ While both rides are classified as "water rapids" rides, patrons on the second ride have far more control over the raft than patrons on the first ride-where water pumps, curves in a fiberglass chute, and gravity controls the raft's movement. ${ }^{141}$

133. Austin, supra note 129 (explaining how kayak rides allowed patrons to move themselves through a water channel).

134. See id. (describing how "Super Speedboats could go up to 35-40 miles an hour and were treated like bumper boats by park attendees").

135. See id. (noting that patrons on rafts could move in different directions based on how they steered the device); Moody v. Aqua Leisure Int'1, No. H-10-1961, 2012 WL 5335842, at *3 (S.D. Tex. Oct. 26, 2012) (illustrating how most water rides "propelled participants by gravity from high elevations on curved channels covered with small amounts of water used to reduce friction during the descent").

136. See NAT'L FAIRGROUND ARCHIVE, supra note 123 (describing how track-based rides, like $\log$ flumes and water-coasters, did not provide patrons with control over their movements).

137. See Moody, 2012 WL 5335842 at *3-4 (involving a patent dispute over a water ride; including a water pump that has two speed settings instead of one - providing a great example of the minor variations that set water rides apart from one another); See Avery \& Dickson, supra note 10, at 299-300 (discussing competition among waterparks to create unique and enticing rides).

138. See NAT'L FAIRgROUND ARChIVE, supra note 123 (comparing log flumes and water slides).

139. See Spinning Rapids Ride, HOPKINS RIDES, http://www.hopkinsrides.com/public/spinning \%20rapids\%20ride/index.cfm (last visited May 8, 2015) (picturing described raft design).

140. See Bigfoot Rapids, KNOTT'S BERRY FARM, https://www.knotts.com/rides/Water-Rides-15-12-21/Bigfoot-Rapids (last visited May 8, 2015) (employing a water raft with no restraints but a wheel to maneuver the raft throughout the ride).

141. Compare id., with Spinning Rapids Ride, supra not 139. 
The example above only speaks to a few of the ride differences that affect a single aspect (patron control) on one type of ride (water rapids). But there are numerous types of water rides, each with countless variations in shape, size, track design, specialty features, etc. Since the 1980 s, those differences have only increased. So, labeling a ride as a "log flume" or "water slide" is just another example of "[p]otato, potahto, tomato, tomahto," 142 because a ride's label does not speak to that ride's unique components and features. Ultimately, the impact of this growing spectrum of ride designs and features is that water rides have infinite variations that are impossible to separate into clear categories.

\section{Early Ride Safety Concerns}

Beginning in the early 1900 s, the race to build 'more extreme' rides precipitated a flood of safety issues. ${ }^{143}$ While safety concerns varied from park-to-park and ride-to-ride, the prevailing practice was to make rides steeper - not safer. ${ }^{144}$ And given that the amusement park industry was unregulated and in its infancy, ride designers enjoyed extreme freedom to experiment with ways to one-up competing rides and parks. ${ }^{145}$

These circumstances painted an ugly picture that stood out in various courts where injured patrons filed suit. Consider the perspective of a judge in 1912. The first wooden roller coaster opened in 1912. ${ }^{146}$ However, 1912 was also the year when an infamous engineering masterpiece - the "unsinkable" Titanic - sank to the bottom of the ocean. ${ }^{147}$ If the best engineering and technology could not save the Titanic, a ship built to ensure a safe voyage, then what hope was there for rides that had experimental features and a purpose of scaring patrons? ${ }^{148}$ After all, patrons injured on a ride in 1912 could not even stop the bleeding by using a Band-Aid-a product invented eight years later. ${ }^{149}$

142. Louis Armstrong \& Ella Fitzgerald, Let's Call the Whole Thing Off, on Ella AND LoUIS AGAIN (Verve Records 1957).

143. See Avery \& Dickson, supra note 10, at 302 (explaining that concerns over patron safety "took a backseat to production efforts and progress" for early amusement parks).

144. See id. at 301-02; REAVLEY, supra note 100, at 315 .

145. Avery \& Dickson, supra note 10, at 302.

146. REAVLEY, supra note 100 , at 315.

147. 1910 to 1919, THE PEOPLE HIST., http://www.thepeoplehistory.com/1910to1919.html (last visited May 8, 2015).

148. Merry Farmer, Life in 1912, MERRY FARMER (Dec. 29, 2011), http://merryfarmer.net/ 2011/12/life-in-1912/.

149. Mary Bellis, The Roaring Twenties, ABOUT.COM, http://inventors.about.com/od/time lines/a/twentieth_3.htm (last visited May 8, 2015). 
As time went on, the various safety concerns condensed into two issues: 1) the lack of ride-testing procedures; ${ }^{150}$ and, 2) the absence of oversight for ride operators. ${ }^{151}$ First, several parks opened new rides before testing for defects and safety flaws. ${ }^{152}$ As a result, patrons served as guinea pigs to test new ride dynamics and features. ${ }^{153}$ Ride operators feared that extensive safety testing would take so long that patrons would abandon the amusement park out of boredom with "older" rides. ${ }^{154}$ Consequently, safety considerations "took a backseat to production efforts," and, as a result, the rates of patron injury and death grew higher and higher. ${ }^{155}$

Second, the lack of oversight in the amusement park industry magnified safety concerns. ${ }^{156}$ Park regulation was "unheard of during the early years of amusement park development." 157 In fact, as of 1929, Wyoming was the only state with any sort of amusement park regulation. ${ }^{158}$ Thus, ride operators were free to build rides without safety restraints, assign untrained employees to operate complex machinery, or employ ride vehicles that were physically or technologically unsound. ${ }^{159}$ The only checks on these practices were after-the-fact lawsuits from injured patrons.

These practices of opening untested and poorly designed rides even continued during the torrent of water-ride innovations in the $1980 \mathrm{~s} .{ }^{160}$

150. See REAVLEY, supra note 100, at 315 (speaking generally about roller coaster safety, and how the demand for "heightened thrills" led to "dangerous experimentation"); Avery \& Dickson, supra note 10, at 308 ("Charles Dinn, an industry giant and world renowned wooden roller coaster designer stated . . . that patrons riding today's roller coasters are guinea pigs.”).

151. See Avery \& Dickson, supra note 10, at 300 (identifying only one state that regulated amusement rides before 1929).

152. See REAVLEY, supra note 100, at 315 (remarking that "higher speeds also required higher safety standards. Despite increased safety measures, however, consumers' demands for heightened thrills did lead to some dangerous experimentation in coaster dynamics").

153. See id.; Avery \& Dickson, supra note 10, at 302, 308 (discussing "trial and error" approach that used patrons to identify ride dangers).

154. See Avery \& Dickson, supra note 10, at 303 ("[A]ttendance figures were climbing exponentially within the amusement industry. As a result, amusement park operators and manufacturer's [sic] were trying to keep pace with the new demands to fulfill guests expectations by offering more advanced versions of amusement rides and devices of yesteryear.").

155. See id. at 302 (highlighting the range of injuries caused by early amusement rides and noting that safety standards that would prevent such injuries took years to appear).

156. See id. at 300, 302 (pointing to early amusement rides where operators did not face state regulation or industry inspections).

157. Id. at 300 .

158. Id

159. See id. at 302-03 (identifying safety and oversight concerns for early amusement rides).

160. See Austin, supra note 129 (illustrating accidents that occurred at a New Jersey amusement park resulting from the lack of testing procedures). 
By 1981, water slide accidents - alone - accounted for over half of amusement park accidents and injuries. ${ }^{161}$ Water rides carried risks of electrocution, drowning, ${ }^{162}$ colliding with another patron, and injury from flopping out of a ride chute and awkwardly landing in a pool of water. ${ }^{163}$

Nevertheless, while courts worried about ride risks, the general American public cared more about "heightened thrills" than safety. ${ }^{164}$ And as park owners gave in to patron demands for riskier rides, patron attendance surged, ${ }^{165}$ despite safety issues, ${ }^{166}$ because extreme rides had become a cultural icon that attracted Americans with a near-magnetic force. ${ }^{167}$ Parks were a place where all American social groups could share thrilling experiences. ${ }^{168}$ In fact, in addition to creating new ride features, amusement parks also provided a host of new foods for patrons to consume with each other-a park feature that introduced Americans to a popular food item known as the hot dog. ${ }^{169}$ Notwithstanding the flavorful foods, it was the shared cultural experience of conquering everincreasing challenges (by riding scarier and scarier rides) that repeatedly reeled patrons in and persuaded patrons to willingly sacrifice safety in exchange for heightened thrills. ${ }^{170}$ In essence, stepping onto a terrifying ride became the American thing to do.

161. Id.
162. Id.; see also Burgess, supra note 2 (noting drowning risk for overturning water rides).

163. See U.S. Water Ride Fatalities (1972-1997), RIDEACCIDENTS, http://www.rideaccidents .com/water.html (last visited May 8, 2015).

164. Avery \& Dickson, supra note 10, at 302; REAVLEY, supra note 100, at 315-16.

165. See REAVLEY, supra note 100, at 315 (suggesting patron awareness of injury risks when they demanded danger in the form of "precipitous descents and faster rides," but noting high amusement park attendance despite that knowledge).

166. See Avery \& Dickson, supra note 10, at 302 (showing that patrons knew that other patrons were being injured on rides, yet most patrons rode on thrill rides despite the possibility of serious injury from an accident).

167. See Galley \& Holcomb, supra note 105, at 79 (describing the cultural significance of thrill rides, and focusing on the suburban desire to escape routine and experience danger).

168. Richard W. Flint, Meet Me in Dreamland: The Early Development of Amusement Parks in America, 8 NineteENTH CENTURY 99-100 (1982); JOANNA M. DOHERTY, AMUSEMENT PARKS AS Landscapes of Popular Culture: AN ANalysis of Willow Grove Park and The WiLDWOODS 1-3 (1999) (analyzing the societal attitudes and perceptions about thrill rides); Hornbuckle \& Manning, supra note 102, at 395 (connecting new American cultural trends with the thrills that amusement parks could offer).

169. See 1 anna Notaro, St. James Encyclopedia of Popular Culture: Coney Island 686 (Thomas Riggs ed., 2014) available at http://go.galegroup.com/ps/i.do?id=GALE\%7CCX273

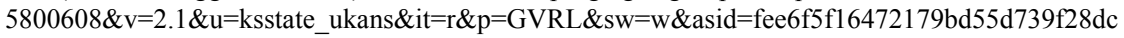
$404 \mathrm{f}$ (pointing to Coney Island as the reason that the hot dog became popular in America).

170. See Galley \& Holcomb, supra note 105, at 91-93 (describing how amusement parks' status as cultural symbols drew in diverse groups of Americans, and explaining how patrons had a nearmagnetic attraction to "chaos created by ... disorienting attractions"). 


\section{Technological Innovations and Modern Precautions}

Technological advances have remedied most of the safety concerns discussed in the prior subsections. Those subsections provide insight into the concerns of the past that prompted courts to expand the liability of ride operators. But, today, water rides are safer, operators must comply with stringent standards, and the amusement industry focuses on safety over sales. ${ }^{171}$ Ultimately, this section demonstrates that yesterday's concerns do not reflect today's water rides.

Today, water rides are more popular than ever. ${ }^{172}$ In a given year, amusement parks record nearly 300 million visits, ${ }^{173}$ and experts project that attendance will only go up in the upcoming years. ${ }^{174}$ With 600,000 employees and $\$ 57$ billion dollars in revenue, ${ }^{175}$ the amusement park industry remains a dominant entertainment source for Americans. While parks still offer new extremes with bigger, taller, and faster rides, ${ }^{176}$ modern parks are also filled with a smorgasbord of gentle rides, such as 'lazy rivers' and 'wave pools' - attractions that provide families and individual patrons with less-intense ride options. ${ }^{177}$

Even the extreme rides are safer than ever. ${ }^{178}$ Modern, high-tech safety devices have significantly reduced the high injury risk that defined

171. See Avery \& Dickson, supra note 10, at 304 (comparing the safety of modern rides compared to early rides).

172. See Petrecca \& Castagna, supra note 3, at $3 \mathrm{~A}$ (providing various statistics about the popularization of water rides as compared to other types of thrill rides).

173. See Charles C. W. Cooke, Ed Markey's Peculiar Crusade, NAT'L Rev. 1 (Feb. 9, 2013, 4:00 AM), http://www.nationalreview.com/article/340033/ed-markeys-peculiar-crusade-charles-c-wcooke (breaking down annual park attendance figures); Amusement Park Attendance and Revenue History, INT'L ASS'N OF AMUSEMENT PARKS AND ATTRACTIONS, http://www.iaapa.org/resources/by -park-type/amusement-parks-and-attractions/attendance-revenue-history (last visited May 8, 2015) (tracing amusement park revenue and attendance).

174. See AECOM, supra note 9, at 27-29 (providing annual attendance at theme parks); Research and Markets: Amusement Parks in the U.S., BUS. WIRE (Dec. 3, 2012, 5:37 AM), http://www.businesswire.com/news/home/20121203005761/en/Research-Markets-AmusementParks\#.VNE5K2TF-PU ("Revenue is expected to improve through 2016, however, as companies seek to lure more consumers with new attractions. Also, the improved economy is projected to help raise consumer confidence, causing demand for entertainment to rise substantially.").

175. See Cooke, supra note 173.

176. See Avery \& Dickson, supra note 10, at 308 (explaining how amusement parks must continue to increase the thrill level of rides in order to satisfy patrons' demands).

177. See Syrett \& Wood, supra note 8 (noting the diverse types of rides).

178. See Lucas K. Murray, Rides: 'New thrills with increased safety', COURIER-PosT (Cherry Hill, New Jersey), May 27, 2012; Tobias Butler, Comment, Rider Beware: Relying on the Courts and A Nationalized Rating System to Address the Duty of Care Owed to Amusement Park Attraction Guests, 9 VAND. J. ENT. \& TECH. L. 369, 374-76 (2006) ("The physics behind today's thrill rides often means subjecting people to much greater forces than before .... Just some of their more popular rides include: Millennium Force, a 310 feet tall steel coaster with a near-vertical drop and 
the industry in the 1980s. ${ }^{179}$ "Emergency shutdown systems, [electronic] sensors, anti-rollbacks, machine guards, warnings, fencing," and back-up systems are common features on most modern rides. ${ }^{180}$

Furthermore, unlike early rides, modern water-ride designs undergo extensive expert evaluation and correction before construction. ${ }^{181}$ Thus, while rides continue to grow bigger and taller, technological advances and prior experience make newer rides safer than smaller, shorter rides from years past. ${ }^{182}$

The absence of water ride oversight is also a thing of the past. ${ }^{183}$ Internal industry standards, independent safety agencies, state legislatures, and courts are all sources of modern water-ride regulations. ${ }^{184}$ The vast majority of states require operators to meet the safety standards set by the American Society for Testing and Materials ("ASTM") - a national ride-safety organization composed of academics, government officials, and industry experts. ${ }^{185}$ These standards, while not entirely uniform, generally require regular inspections and safety testing,

top speed over 90 miles per hour... Mean Streak, a 161 feet tall wooden coaster, which are historically known for rough rides, that travels over 60 miles per hour ... and Power Tower, a set of towers which use pressurized air to either blast riders up or pull riders down over 200 feet along the sides of the towers. These experiences represent a small sampling of the 68 mechanical rides this one park offers.... While this may seem unsettling to the ordinary reader, it does not translate into a disregard for the safety of riders. In fact, the modern roller coaster is much safer than many of its predecessors.... Safety is the first concern of any park operator. In addition to strict standards imposed by park operators, forty-two states have enacted requirements for ride safety. In 2003, the International Association of Amusement Parks and Attractions (IAAPA), working with the National Safety Counsel, found approximately 2,486 guest injuries occurred during the 2001-2002 season while approximately 300 million people visited facilities with transportation-based attractions. Therefore, these major machines are not untamed beasts.").

179. See Avery \& Dickson, supra note 10, at 305; Murray, supra note 178 (pointing to new braking technologies and harness mechanisms).

180. Avery \& Dickson, supra note 10 , at 305.

181. See id. at 311 (noting majority of past issues were design defects and not operator mistakes).

182. See id. at 304-05 (linking increased safety with increased ride complexity); Goodfried, supra note 38, at 2 ("Since accidents commonly occur at theme parks, amusement park liability is a timely issue. Although accidents in amusement parks are as common as cotton candy, serious injuries are rare. In fact, no serious injuries were reported in 2004 at amusement park sites in California, with more than 110 million rides given.").

183. See Cereola \& Foucar-Szocki, supra note 28, at 51-52 (noting that modern regulations also apply to water rides).

184. See id. at 51-53; Avery \& Dickson, supra note 10, at 304, 310-11 (pointing out the various sources for ride regulations); Cooke, supra note 173 (explaining the pressure on ride operators from insurance carriers to maximize safety features).

185. Avery \& Dickson, supra note 10, at 304. While ASTM stands for "American Society for Testing and Materials," the organization operates globally, and the same ASTM standards often apply in several different countries. See About ASTM International, ASTM, http://www.astm.org/ ABOUT/overview.html (last visited May 8, 2015). 
and several poorly operated or improperly designed rides have been shut down as a consequence of failing to comply with the ASTM's standards. ${ }^{186}$

Furthermore, despite being business competitors, park operators collect and share testing and safety information with one another. ${ }^{187}$ This pool of information flushes out rare and undiscovered risks and enables ride operators to identify and implement the most effective safety procedures. ${ }^{188}$

Nevertheless, media reports and proponents of increased ride regulation allege that modern rides are more dangerous than ever before. ${ }^{189}$ Initially, investigative reports that show increased injury rates are often based on incomplete information because there is no requirement for parks to disclose all company data for every thrill ride. ${ }^{190}$ So, the public may never see company reports that show years of flawless inspections and injury-free operation of a certain ride. And, as water parks do not hand out company logs to every curious reporter, negative reports often omit strong safety records and overemphasize isolated, unrepresentative injuries. ${ }^{191}$ Unfortunately, politicians and media members have sometimes tried to garner public attention and popularity by sensationalizing isolated ride incidents and exploiting the American public's excitement and interest in thrill rides. ${ }^{192}$ But, motive aside, injury reports are usually based on incomplete data.

More importantly, even complete, raw injury statistics fail to reveal whether the ride operator or a patron's careless conduct caused the

186. See Austin, supra note 129 (pointing out various rides that have been closed as a result of failing safety inspections); Cereola \& Foucar-Szocki, supra note 28, at 52 (noting that the lack of regulatory oversight for thrill rides is a thing of the past); Avery \& Dickson, supra note 10, at 311 (highlighting various mandatory industry inspections).

187. See Avery \& Dickson, supra note 10, at 304 (explaining the pooling of information between parks).

188. See id. (demonstrating the benefits of sharing ride data between parks).

189. See Anna Mulrine, Not-So-Amusing Rides, 129 U.S. News \& World ReP. 59 (Aug. 14, 2000) (showing Congressional appeal to public over minor ride incidents); Goodfried, supra note 38, at 4 ("While an accident at a theme park garners much media attention, it rarely results in anything more than minor injuries.").

190. See Avery \& Dickson, supra note 10, at 307 (noting that some parks do not respond to accident surveys); Cereola \& Foucar-Szocki, supra note 28, at 47 (explaining that high-fatality reports are inaccurate because there is no central reporting requirement to check that statistics are precise and not manipulated); Austin, supra note 129 (noting that parks do not report all statistics).

191. See Avery \& Dickson, supra note 10, at 300 (explaining the bias in ride accident reports).

192. See id. at 301,303 (providing examples of political sensationalism as related to ride accidents). 
accident. ${ }^{193}$ Further, even with a blameless patron, the injury may not be attributable to the ride operator. While operators "run" the ride, operators do not design, construct, or manufacture the ride or the ride's components. So instead of an operational problem, an injury may result from a flaw in the ride's design, a construction error, or a manufacturing defect in a particular ride component-distinctions that are masked by raw injury numbers. ${ }^{194}$

This is not to say that modern water rides are completely safe and injury-free. ${ }^{195}$ Water-ride incidents, resulting in various injuries from broken bones to drowning after capsizing, ${ }^{196}$ form the basis for more personal injury lawsuits than any other type of thrill-ride accident. ${ }^{197}$ These injuries can be straightforward, such as skin lacerations from sliding over a section of chipped fiberglass, or more complex, such as injuries that raise questions about how frictional forces between a patron's leg and the water slide contribute to development of alopecia patches on the patron's body. ${ }^{198}$ And one can imagine the headaches of determining what caused a patron to lose contact with a slide's surface, over-accelerate above the water before a turn, and then crash into the slide wall with enough force to kill the patron. ${ }^{199}$ In reality, modern water ride injuries often fit into the complex category because of the various unique factors that can contribute to a patron's injury. So, even today, it may be impossible to fully predict and prevent the risk of injury from each twist and turn for each individual patron. ${ }^{200}$

However, even without a pinpoint risk calculation for each patron, modern rides are safer than ever. In fact, even according to the data from investigative reports showing the highest ride-injury rates, Americans are still 1,000 times more likely to die from being struck by lightning or

193. See Mulrine, supra note 189 (indicating that "rider stupidity causes many accidents. In at least one, a rider pushed a restart button just as others were disembarking").

194. See Avery \& Dickson, supra note 10, at 305-06, 311 (noting the various alternate causes for a ride accident).

195. See id. at 305, 311 (listing continued concerns with water rides).

196. See id. at 305 ("the industry continues to experience minor and major losses; some of which are highly publicized and a cause for concern. The riding public has incurred injuries and deaths such as ... the capsizing and drowning of occupants on a river ride, ... drowning at water parks, broken necks on inflatable's [sic].”).

197. See Austin, supra note 129 (focusing on water rides as the main source of injury).

198. Brian B. Adams, Water-Slide Alopecia, 67 CuTIS 399, 399-400 (2001), available at http://www.cutis.com/fileadmin/qhi_archive/ArticlePDF/CT/067050399.pdf.

199. See Piotr Szczepaniak \& Ryszard Walentyński, Safety of Recreational Water Slides: Numerical Estimation of the Trajectory, Velocities and Accelerations of Motion of the Users, in COMPUTATIONAL SCIENCE-ICCS 2007, at 219-20 (Yong Shi, et al. eds., Springer Berlin Heidelberg 2007).

200. Id 
falling in a bathtub than from a roller coaster accident: "a one-in-300million chance." 201 In fact, an engineering group recently compared several ride-injury reports and concluded that "injury rates at amusement parks are 'significantly lower' than those of 'other activities[,] such as owning bunk beds, skateboards, sleds, or bicycles." 202 Furthermore, of the hundreds of millions of patrons who rode thrill rides in 2011 , only five percent of injured patrons required hospital care; ${ }^{203}$ and only 1.5 percent of injured children were hurt badly enough to require hospitalization. ${ }^{204}$ So modern rides are not only significantly safer than early thrill rides, but the modern risk of serious injury is also microscopic.

\section{Drowning Water-Ride Developments in a Crest of Common Carrier Concerns}

Drawing from the previous background sections for support, this final background section traces the historical changes in how courts link common-carrier concepts and various types of water rides. Specifically, this section demonstrates how courts inconsistently respond to changes in water-ride design and technology by emphasizing different-and sometimes conflicting-interests and concerns when deciding which liability standard to apply to ride operators. ${ }^{205}$ By mixing different tort and common-carrier concepts with different types of water rides, courts continue to mystify the meaning and effect of heightened liability standards. More concerning is that this constant confusion defeats the purpose of a heightened standard by disrupting national industry efforts at improving ride safety.

201. Cooke, supra note 173.

202. Id.; see also Goodfried, supra note 38, at 5 ("With any recreational activity, from daredevil extreme skiing to ... golf, there is always some risk of serious injury or fatality. In 2004, four people died as a result of accidents at fixed-site amusement parks.... Four fatalities out of $169,100,000$ visitors is a ratio of one out of every 42,275,000, which makes the act of driving your own car to an amusement park far more dangerous than embarking on a ride once at the park. Understandably, some argue that four fatalities a year are still four too many. However, raising the safety standard is not the answer. Heightened standards will allow more lawsuits, but will not decrease the number of fatalities.").

203. Petrecca \& Castagna, supra note 3 , at $3 \mathrm{~A}$.

204. JoNel Aleccia, Amusement Rides Hurt 4,400 Kids a Year, Large Study Finds, NBC NEWS (Apr. 30, 2013, 9:02 AM), http://vitals.nbcnews.com/_news/2013/05/01/17988578-amusement-rid es-hurt-4400-kids-a-year-large-study-finds?lite.

205. See Avery \& Dickson, supra note 10, at 309-10 (offering a discussion of the various flaws with a piecemeal focus on ride standards and liability). 
Courts did not apply common carrier concepts in the first amusement park cases. Before the $1900 \mathrm{~s}$, American ride operators were only liable for ordinary negligence. ${ }^{206}$ As noted earlier, this period of time featured water rides that were free of complex machinery, such as simple slides and basic boats. ${ }^{207}$

The beginning of the 1900s marked the period when American courts started to hold ride operators to differing liability standards. ${ }^{208}$ In 1902, a New York court decided one of the first water-slide cases in Barrett v. Lake Ontario Beach Improvement Co. ${ }^{209}$ In Barrett, a fifteenyear-old boy died from falling off of a twenty-five-foot tall water slide. ${ }^{210}$ The trial court followed the lead of earlier courts and held that the park operator was required to exercise reasonable care in constructing and operating the slide. ${ }^{211}$ In finding for the park, the court explained that it was reasonable for the park to build a shorter railing around the slide's platform because "the character and purpose of the [slide]... was simply and solely for purposes of amusement." ${ }^{212}$ Thus, according to the trial court, patrons came to the slide seeking thrills, and that purpose made the risk of falling from a wet slide obvious, possibly even enticing, to patrons. $^{213}$

Yet on appeal, the appellate court reversed the decision, holding that the slide operator had a "stricter measure of duty" than reasonable care. $^{214}$ The appellate court argued that, even if risks were obvious or enticing to patrons, the operator had to minimize all foreseeable risks to satisfy this heightened standard of care. ${ }^{215}$ The court explained that, like

206. See Bendick v. Potts, 40 A. 1067, 1068 (Md. 1898) (requiring railway car passenger to prove operator was negligent).

207. See Decatur Amusement Park Co. v. Porter, 137 Ill. App. 448, 449-50 (Ill. App. Ct. 1907) (applying ordinary care where amusement park operated a large, 10-foot-deep pond).

208. Compare Rayfield v. Sans Souci Park, 147 Ill. App. 493, 498-99 (Ill. App. Ct. 1909) (applying ordinary care standard to ride operation), with O'Callaghan v. Dellwood Park Co., 149 Ill. App. 34, 37-38 (Ill. App. Ct. 1909) (applying highest degree of care standard to operation of scenic railway in amusement park).

209. See Barrett v. Lake Ontario Beach Improvement, Co., 68 A.D. 601, 602-03 (N.Y. App. Div. 1902) (involving twenty-five foot, six-inch tall water slide with a wooden platform that was surrounded by four-foot tall railing).

210. See id. at 602,611 .

211. See id. at 605-09 (requiring exercise of ordinary care and measuring standard of care by risks obvious to park but not patron).

212. See id. at 605 (connecting risks with injuries).

213. See id.

214. See Barrett v. Lake Ontario Beach Improvement, Co., 66 N.E. 968, 970 (N.Y. 1903) (changing the standard of care).

215. See id. (requiring that "risks should be minimized to the extent that reasonably prudent men might foresee the necessity of doing so. The risk of falling from the platform may have been 
a common carrier, the slide operator invited the public to use the slide, and, like passengers, the public thus assumed that the operator did everything necessary to make the ride safe and eliminate injury risks. ${ }^{216}$ Thus, even for the most obvious risks, the operator had a duty to take extra precautions for the patrons' safety. ${ }^{217}$ However, as with early common carrier cases, the court never clarified how to determine when the operator had done enough to satisfy this "stricter measure of duty." 218 In addition, the court failed to clarify if the heightened liability standard applied only to water-ride operation-meaning the maintenance, supervision, and control of the ride ${ }^{219}$ - or also applied, as a matter of premise liability, to the slide's physical construction and modification. ${ }^{220}$

Following Barrett, several courts started to apply the common carrier standard to a variety of rides. ${ }^{221}$ Unfortunately, courts were inconsistent and unpredictable in deciding when to apply the standard. As a result, courts either held similar types of rides to differing standards, or courts gave divergent rationales for holding dissimilar rides to the same standard. ${ }^{222}$ For example, in 1909, one Illinois court held the operator of a glass maze to a reasonable care standard. ${ }^{223}$ But - that same yearanother Illinois court both held the operator of a scenic train ride to the heightened common carrier standard and also applied a rebuttable presumption of operator negligence. ${ }^{224}$ The latter argued that scenic train

apparent to persons using it, but those persons had the right to assume that they went there without incurring any risk which might have been reasonably anticipated by the proprietor").

216. See id. (noting amusement rides may have inherent risks, but the duty is first on the park owner to construct rides that increase ride safety with respect to those inherent risks).

217. See id. (requiring parks take "every reasonable care" when constructing water slides).

218. See Chavez v. Cedar Fair, LP, No. WD 75373, 2013 Mo. App. LEXIS 843 at*14-17 (Mo. Ct. App. July 16, 2013) (noting differences between negligent construction and negligent operation of amusement ride).

219. See id. (listing different torts for negligent construction, operation, and maintenance, but not identifying elements or applicability of a specific tort in this case).

220. See Barrett, 66 N.E. at 969-70 (discussing public invitee concerns and park duties for ride construction).

221. Compare Rayfield v. Sans Souci Park, 147 Ill. App. 493, $498-99$ (Ill. App. Ct. 1909) (applying ordinary care standard to ride operation), with O'Callaghan v. Dellwood Park Co., 89 N.E. 1005, 1006 (Ill. 1909) (applying highest degree of care standard to operation of scenic railway in amusement park).

222. See supra notes 14-15, 208 (discussing inconsistent standards and outcomes in various water-ride cases).

223. See Rayfield, 147 Ill. App. at 498-99 (denying application of res ipsa loquitor and finding operator maintained maze "in a safe manner").

224. See O'Callaghan, 89 N.E. at 1006-07 (requiring "the highest degree of care and caution for the safety of its passengers ... consistent with the ... practical operation of the railway"). 
rides and roller coasters were like railroad operators-the clearest example of a common carrier for most courts. ${ }^{225}$

However, the court's holding was based more on broad public policy concerns than on a clear test to determine which amusement rides were enough like common carriers to justify a heightened liability standard. ${ }^{226}$ As time went on, several courts agreed that roller coasters were similar to railroad trains, but those courts did not agree over which tort principles should apply to coaster operators. ${ }^{227}$ The same division followed for scenic railway rides, and courts steadily broadened the web of confusion that left more and more operators in the dark about their duty to park patrons. $^{228}$

Eventually, even for the same type of ride, some courts called for the heightened standard, ${ }^{229}$ others added a rebuttable presumption, ${ }^{230}$ and yet others maintained a reasonable care standard. ${ }^{231}$ Eventually, as parks created a variety of rides with different features, sizes, speeds, and technological innovations, courts were doused with a deluge of ride classifications, features, and designs. Unfortunately, each new case called for a new trip to the common carrier buffet - where courts seemed to fill their plates with different factors and new concerns. ${ }^{232}$

225. See Webb, supra note 42, at 1088 (explaining that "[t]he law of negligence of the late nineteenth century was to a considerable extent the law of railway accidents.").

226. See O'Callaghan, 89 N.E. at 1006-07 (noting utmost care and diligence was required of coaster operators because the ride posed a potentially great danger of harm).

227. See Barr v. Venice Giant Dipper Co., 32 P.2d 980, 980 (Cal. Ct. App. 1934) (linking roller coaster with common carrier concepts).

228. Compare Bibeau v. Fred W. Peace Corp., 217 N.W. 374, 376 (Minn. 1928) (citing O'Callaghan, 89 N.E. at 1007) (applying res ipsa loquitor and holding that "the proprietor of a roller-coaster must exercise the highest degree of care and caution for the safety of his passengers, and do all that human foresight can reasonably require, consistent with its practical operation, to prevent accidents to them.”), with Best Park \& Amusement Co. v. Rollins, 68 So. 417, 418 (Ala. 1915) (holding scenic railway operator in amusement park to highest degree of care due to common carrier application).

229. See Bibeau, 217 N.W. at 376 (charging operators of roller coasters with highest degree of care).

230. See Gomez v. Superior Court, 113 P.3d 41, 47-48 (Cal. 2005) (surveying different common carrier concepts as applied to thrill rides).

231. See Wash. Luna Park Co. v. Goodrich, 66 S.E. 977, 977 (Va. 1910) (requiring "due and proper care" in operation of roller coasters).

232. Sometimes courts even added new legal questions to the mix. For example, after concluding that the carrier standard applied to a ride operator, one California court pondered when the "passenger-carrier relationship" began and ended. See Orr v. Pac. Sw. Airlines, 257 Cal. Rptr. 18, 21 (Cal. Ct. App. 1989) (quoting Dayton v. Yellow Cab Co., 193 P.2d 959 (Cal. Ct. App. 1948)) (adding even more complexity and confusion to the carrier standard by concluding that the relationship lasts until " "the passenger reaches a place outside the sphere of any activity of the carrier which might reasonably constitute a mobile or animated hazard to the passenger."”). 


\section{ANALYSIS}

This Comment will first analyze whether water-ride operators should be subject to the heightened common carrier standard or, instead, a reasonable care standard with a rebuttable presumption of operator negligence. To make that determination, the analysis below answers three questions. First, can courts consistently distinguish water rides and common carriers based on identifiable similarities and differences? Second, if courts cannot consistently make that distinction, then should all water-ride operators be held to the heightened standard or the reasonable care standard? Third, is a rebuttable presumption of operator negligence necessary for a particular liability standard to be effective?

\section{A. Flushing out the Differences Between Water Rides and Common Carriers}

\section{Similarities and Differences Between Water Rides and Common Carriers}

Courts eventually pointed to so many different ride aspects, policy goals, and common carrier characteristics that it became impossible to draw meaningful lines between rides that should and should not be subject to the common carrier standard. ${ }^{233}$ The traditional justifications for applying either the heightened standard or a rebuttable presumption were broken up, altered, and sometimes ignored altogether. ${ }^{234}$ Specifically, courts disagreed over: (1) control factors; (2) the effect of a patron's purpose; and (3) public policy goals. Eventually, whether a ride looked tall, fast, or scary became more important than a detailed comparison of ride features and traditional common carrier characteristics. $^{235}$ Even then, courts disagreed over which rides were

233. See Butler, supra note 178, at 379 ("Protection has not solely been left to the legislatures, however. The courts also have a place in the debate on an amusement park operator's duty of care. Through a combination of statutory clauses and common law decisions, the state courts have sharply divided in answering what an amusement park operator owes to his guests.").

234. See id.; Gomez, 113 P.3d at 42-45 (Cal. 2005) (surveying different common carrier concepts as applied to thrill rides); Ronald J. Cerola, Fixed Site Amusement Rides: Duty Of CareAn Ordinary Negligence Standard Or Common Carrier Liability?, 4 Fla. InT'L. U. Hospitality L. 1, 9 (2012), available at http://hospitalitylawyer.com/wp-content/uploads/VolumeIV_Article1.pdf ("The jurisdictions that have imposed common carrier liability upon amusement ride operators and thus requiring a heightened degree of care are just as numerous as those not requiring such, and just as diverse in their rationale in arriving at their conclusions.").

235. See, e.g., Best Park Amusement Co. v. Rollins, 68 So. 417, 418 (Ala. 1915) (focusing on "[t]he steep inclines, sharp curves and great speed" when applying heightened standard of care to amusement park ride) (quoting O'Callaghan v. Dellwood Park Co., 89, N.E. 1005, 1006 (Ill. 1909). 
"tall, fast, or scary enough" to warrant a heightened liability standard. ${ }^{236}$ And with water rides, those disagreements stormed quickly and seeped deep into courts' thrill ride jurisprudence. ${ }^{237}$

\section{a. Control Factors}

First, despite the overflow of divergent approaches, courts often examined the control disparity between operators and patrons because the hallmark of early common carrier jurisprudence was operators' exclusive control over a carrier. ${ }^{238}$ Roller coasters presented an easier case for the control analysis because patrons-locked into a ride apparatus - could not alter the coaster's speed or direction; only the ride operator controlled those functions. ${ }^{239}$ In contrast, water rides typically provided patrons with greater mobility. ${ }^{240}$ For example, on water slides without rafts, there was usually no safety bar or harness to restrain a patron's movement and control. ${ }^{241}$ However, with log flumes, straps and bars were commonly installed to keep patrons inside the boat during the ride. $^{242}$ Ironically, while the log flume restricted patrons' control and ability to move away from potential harm, it was the water slide that courts first subjected to a heightened standard of care. ${ }^{243}$

236. Compare id. (expressing concern over steep inclines on roller coasters), with Lamb v. B \& B Amusements Corp., 869 P.2d 926, 931 (Utah 1993) (explaining that, unlike passengers on early common carriers, amusement ride patrons "expect ... high speeds, steep drops, and tight turns").

237. See infra Part III.A.3.

238. See, e.g., Tenn. State Fair Ass'n v. Hartman, 134 Tenn. 159, 161-63 (Tenn. 1916) (focusing exclusively on control disparity for common carrier application to amusement ride); Gomez, 113 P.3d at 47-48 (Cal. 2005) (surveying heightened standard as applied to thrill rides and noting common control consideration); Cerola, supra note 234, at 12 ("[F]indings of common carrier are based upon the passenger's ceding of control to the carrier and the passenger's inability at that point to do anything to prevent an injury.").

239. See Chavez v. Cedar Fair, LP, No. WD 75373, 2013 Mo. App. LEXIS 843, at*13 (pointing to earlier cases where coaster operator had exclusive control and ability to prevent harm).

240. See id. at *4, *13 (pointing out that patron was able to let go of raft straps and fly into a fellow patron in the raft).

241. See Tenn. State Fair Ass'n, 134 Tenn. at 161-63; Hartman v. Tenn. State Fair Ass'n, 134 Tenn. 149, 156-58 (Tenn. 1916) (both cases discussing the same ride and inability of patrons to escape harm due to restraints on coaster).

242. See Burgess, supra note 2 (explaining that log flume passengers could not escape the ride because they were belted in with straps); Cedar Point Accident, supra note 2, at 3A (discussing restraint in overturned log flume boat).

243. See Matenaer v. Gatlinburg Waterslide, Inc., No. 79-1519, 1981 U.S. App. LEXIS 19901, at *2 (6th Cir. Feb. 24, 1981) (finding waterslide had "same duty of care as a common carrier."). 
As technological advances produced a cascade of new ride features, ${ }^{244}$ courts reached different conclusions about the effects these new features had on patron control. These ride characteristics - such as ride height, slick surfaces, high speeds, and high volumes of water from large pumps ${ }^{245}$-altered patrons' control, but courts were unsure what that meant for liability purposes because early common carrier cases did not involve towering water slides or mechanical pumps. ${ }^{246}$ Due to this lack of guidance, courts drifted away from the traditional common carrier rationales and historical characteristics and, instead, latched on to the various characteristics and features of modern rides. For example, whether a ride had a raft or seatbelts was sometimes dispositive of what liability standard would apply - an approach that ignored other ride characteristics that increased or decreased patron control. ${ }^{247}$

While some courts attempted to weigh all of the similarities and differences between a water ride and a common carrier, this process produced unpredictable outcomes because, without a common balancing test, courts weighed different factors in different ways. ${ }^{248}$ For example, the Missouri Court of Appeals engaged in this weighing process in Chavez v. Cedar Fair, a case involving a patron who, while traveling down a 70 -foot-tall water slide with several other individuals, collided with another patron in the same raft. ${ }^{249}$ The court held that "the appropriate standard of care... depends upon the facts and circumstances of a given case." 250 In spite of that call for a detailed analysis of the water slide's unique characteristics, the court, considering cases involving roller coasters and airplanes, only evaluated one factor-

244. See Goodfried, supra note 38 , at 3 (detailing how technological advances enabled ride to "range from bloodcurdling roller coasters with 200 -foot drops, to children's rides that slowly move passengers through rooms filled with singing animatronics.").

245. See Chavez, 2013 Mo. App. LEXIS 843 at *13-17 (determining the applicable liability standard for the operator of a modern, complex water slide by applying precedent from cases involving roller coasters, primitive water rides, and injuries from slick spots throughout park premises).

246. See Kaczorowski, supra note 42, at 1165 (explaining that early common carriers were landbased stagecoaches and railroad trains).

247. See Chavez, 2013 Mo. App. LEXIS 843, at*1, *9 (involving a patron who was not in an enclosed vehicle, was not restrained by any belt or harness, and shared control over the raft and risk of injury because releasing her grip on the raft's straps or uncrossing her legs during the ride enabled ejection and collision with co-patrons).

248. See id. at $* 5$ (holding that "the operator had complete control and its patrons were dependent upon the operator for their safety. Under such circumstances, Cedar Fair had a duty to operate Hurricane Falls with the highest degree of care"). But there were no other factors that the court analyzed, despite calling for an evaluation of all the circumstances. Id. at *5.

249. Id. at $* 1, * 9$

250. Id. at $* 4$. 
the operator's control-before applying the heightened standard. ${ }^{251}$ But focusing exclusively on the operator comes dangerously close to imposing a strict liability standard because the patron's careless conduct is either overlooked or ignored. ${ }^{252}$ In fact, the court's holding was at odds with the patron's own theory: that the operator gave the patron too much control by failing to install a restraining harness in the raft. ${ }^{253}$ One commentator highlighted additional control distinctions in the case:

[F]orces on a coaster are such that these restraints are designed to restrict the guest's freedom of movement significantly. ... But a water slide is fundamentally different. By its nature, guests have far more control .... Guests on a water slide cannot be restrained ... as to do so would potentially create a drowning hazard. Differences in guest weight, guest distribution in the raft, and body position, which are all beyond the operator's complete control, can lead to significantly different riding experiences .... Moreover, a rider on a water slide has the ability to do just about anything once that raft leaves the dispatch point, thus creating a risk of injury an operator cannot control. A guest that wants to jump out of a roller coaster train must work hard to do it. A guest that wants to jump out of the raft on a water slide simply has to do it. ${ }^{254}$

The Missouri Supreme Court also disagreed and recently overruled the appellate court's decision. However, despite the appellate court's extensive discussion of the operator's control, the supreme court's majority opinion in Chavez largely skipped over the control disparity, as the majority focused on patrons' purpose for riding the slide and the lack of a sufficient risk of harm to justify a heightened liability standard. ${ }^{255}$ In contrast, the dissenting opinion spoke almost exclusively about the control disparity between the injured patron and the slide operator. ${ }^{256}$

When compared, these three Chavez opinions show how courts-in a

251. See id. at *2-3 (comparing control on water ride to rollercoaster and then concluding the analysis).

252. See Webb, supra note 42, at 1085 (noting that "people could both watch out for their own safety and precipitate their own injuries" and thus the heightened standard was supposed to account for that to protect carriers from becoming insurers of "passenger safety").

253. See Chavez, 2013 WL 3660372, at *1, *9 (where the injured plaintiff argued that the defendant failed to provide adequate "restraints or other devices"); see also Erik H. Beard, Planes, Trains, \& Waterslides? Missouri Imposes Heightened Liability Standard On Amusement And Water Parks, Legal Roller COASTER (Jul. 19, 2013, 2:56 PM), http://www.legalrollercoaster.com/2013/ 07/planes-trains-waterslides-missouri.html (noting that the patron's argument about the lack of safety devices spoke to a flaw with the ride's design and construction, which is not a responsibility of a ride operator).

254. Beard, supra note 253.

255. See Chavez v. Cedar Fair L.P., No. SC 93658, 2014 WL 5856696, at *4, *7-8 (Mo. 2014).

256. See id. at *9 (Teitelman, J., dissenting). 
single case involving the same ride-are inconsistent in selecting the number and type of ride characteristics to analyze. Moreover, courts that do examine the same characteristics may weigh them differently and reach different conclusions. These type of inconsistencies are shining examples of how focusing on certain ride characteristics generates confusion and division - across the nation - over the appropriate liability standard for water-ride operators. ${ }^{257}$ So, while the Missouri Supreme Court's ruling eliminates a significant amount of confusion about liability standards for thrill rides, the root cause of that confusion remains intact.

\section{b. Patron Purpose}

Second, in addition to the control analysis, courts have also considered the patron's purpose for getting on a water ride. ${ }^{258}$ It should come as no surprise that courts disagree over the relationship between a patron's purposes and the scope of an operator's duty. ${ }^{259}$ Some courts felt that a heightened standard was inappropriate because patrons' expectations and purpose in paying for admission to an amusement park

257. See Beard, supra note 253 (arguing that "the decision in Chavez v. Cedar Fair is a very big deal - particularly for operators in the State of Missouri. Left unchecked, this opinion just increased the liability exposure for every operator in the state"); Kaczorowski, supra note 42, at 1155 ("The divisions among state judges seem to be attributable to different understandings of the nature of the American economy and economic relationships, of the nature of common carriers as public or private enterprises, and of the consequent public need for the intervention of the courts to adjust the conflicting interests of shippers and carriers through law."); see also Cerola, supra note 234, at 6, 8; Avery \& Dickson, supra note 10, at 309-10 ("There still is a large faction of . . . operators ... who are simply unaware, choose to ignore, or do not have to abide by the current ... standards. The inconsistent application and use of standards across the USA potentially aides in unnecessarily placing patrons in harms-way.... [A]cross the USA, amusement ride and device owners and operators are being subjected to varying approaches to industry safety based on state-by-state objectives and concerns. The existing standards are being interpreted and applied inconsistently as a result. Many of the requirements to operate an amusement ride or device change based on the number of rides, employees, and/or location of the facility or temporary event. This haphazard approach does little to assist in the unification of safety efforts industry wide and potentially inhibits the closure of any gaps realized from previous incidents or situations.... [E]ach group is acting independently from one another yet they are trying to achieve the same goals.... It has the appearance that industry efforts will become watered-down if this trend continues.").

258. See O'Callaghan v. Dellwood Park Co., 89 N.E. 1005, 1006-07 (Ill. 1909) (noting roller coasters, like elevators and trains, are "wholly under the control of" the operator).

259. See Cerola, supra note 234, at 6, 8-9 (noting that "courts in various jurisdictions have emphasized different criteria in arriving at the same conclusion that operators of amusement rides are not common carriers subject to a heightened standard of care. The determinative factors appear to" be the patron's purpose, movement control, and the carrier's purpose). 
was to experience extreme sensations, ${ }^{260}$ dangers ${ }^{261}$ and thrills. ${ }^{262}$ This expectation for operators to create a feeling of danger for ride patrons stands in sharp contrast to the traditional role of common carriers to merely provide the public with transportation to and from the workplace. ${ }^{263}$

Other courts argued that a patron's purpose made no difference in extending the heightened standard because some passengers on early carriers rode along for recreation, ${ }^{264}$ such as sightseeing or just for the sake of traveling. ${ }^{265}$ These courts also noted that amusement ride operators were technically common carriers because rides were "open to the public, for carriage upon a fixed route and operated for reward."266

\section{c. Public Policy Justifications}

Third, courts also provided different public policy justifications for applying the heightened standard to water-ride operators. Most of these policy concerns related to vulnerable patrons or a desire for water-ride operators to adopt additional safety precautions. ${ }^{267}$ Sometimes courts mixed concerns with vulnerable patrons with the control disparity by

260. See id. at 6,8 (discussing cases where the patron's purposes and expectation of danger was the justification for denying common carrier liability); Kaczorowski, supra note 42, at 1148 (explaining how early common carriers served a key "public interest").

261. Nalwa v. Cedar Fair, LP, 290 P.3d 1158, 1160 (Cal. 2012) (applying assumption of risk doctrine to injuries from bumper cars because patrons assume and expect inherent injury risks by riding on thrill rides).

262. See Avery \& Dickson, supra note 10, at 299-300 (discussing the expectations of patrons).

263. See Cerola, supra note 234, at 6 (discussing a case holding that an "amusement park was not a common carrier simply upon the basis that the defendant did not provide public transportation in the traditional sense that was ordinarily associated with common carriers. It . . did not perform a public service in transporting passengers from one point to differing points of location, but merely provided transport on its own premises.").

264. See id. at 12 (discovering that "jurisdictions that impose common carrier liability do so based upon the finding that amusement ride operators simply fit the technical definition of a common carrier in that they are open to the public, for carriage . . . and operated for reward."). The patron's purpose is thus a secondary consideration with little weight. Id. However, the operator's control and risk of harm are still important factors for several courts.

265. See Gomez v. Superior Court, 113 P.3d 41, 48 (Cal. 2005) (noting recreational uses of trains and other earlier carriers and accordingly holding that purpose "does not determine whether the provider of the transportation is a carrier for reward"); O'Callaghan v. Dellwood Park Co., 89 N.E. 1005, 1006-07 (Ill. 1909) (analogizing by asking if "the motive which causes a person to take passage make any difference as to the degree of responsibility with which the carrier is charged? Passenger elevators are frequently operated in buildings in order to convey persons to some vantage point where they can overlook a great city or some other object of interest, and trips on electric cars are often made solely for pleasure.").

266. Cerola, supra note 234, at 12; see, e.g., Lewis v. Buckskin Joe's, Inc., 396 P.2d 933, 93839 (Colo. 1964) (linking control and patron vulnerability, but ignoring patron purpose).

267. See supra notes 223-26 (providing examples of different policy rationales). 
arguing that patrons had entrusted their safety to the ride operator and were thus helpless to avoid injury due to the inability to control the ride's direction or speed. ${ }^{268}$

Courts' main concern with vulnerable patrons was the degree to which patrons understood the risk of injury on various rides. ${ }^{269}$ Some courts reasoned that all patrons on extreme rides, like roller coasters, were "subjected to much greater danger than is generally realized." 270 Other courts disapproved of ride operators' advertising of parks and rides in a way that appealed to children because children, it was thought, could not appreciate the risks involved with the various rides. ${ }^{271}$ With water rides, some courts also pointed out the unique and less-obvious risk of drowning ${ }^{272}$ or being electrocuted from water-to-wire contact while on a water ride. ${ }^{273}$

While these policy concerns were understandable, courts often ignored the traditional common carrier characteristics in favor of individual ride features and abstract public policy goals. ${ }^{274}$ As a result, the heightened standard slowly detached from its common carrier roots, and courts focused on an even broader set of concerns that deepened the well of inconsistencies and expanded the pool of issues that divided courts across the nation. ${ }^{275}$

268. See Chavez v. Cedar Fair, LP, No. WD 75373, 2013 Mo. App. LEXIS 843, at *5, *7 (Mo. Ct. App. July 16, 2013).

269. Bibeau v. Fred W. Pearce Corp., 217 N.W. 374, 376 (Minn. 1928) (applying heightened standard of care based on alleged patron ignorance of roller coaster risks).

270. Id.

271. See Gomez v. Superior Court, 113 P.3d 41, 45-46 (Cal. 2005) (discussing limited ability of children and other patrons to appreciate risks of roller coasters).

272. See Kyia v. Lake Compounce Theme Park, Inc., No. CV 010807302S, 2002 WL 1949222, at *1-2 (Conn. Super. Ct. July 22, 2002) (noting concern over six-year-old boy who "was permitted to ride alone in a 'Lake Plunge' ride down a water slide in an inner tube which flipped over, causing the decedent to be thrown beneath the surface of the lake and suffer injuries which led to his death six days later," and connecting the injury to "“failing to see that infant plaintiff was too small to ride said water ride without an adult,' supplemented by all the other allegations of the ride's height and lack of safety measures, adequately sets forth a claim of reckless conduct"); see also Austin, supra note 129 (discussing patrons who drowned in wading pools but connecting their deaths to their choice to enter the pool without knowing how to swim).

273. See Austin, supra note 129 (discussing patron who was electrocuted after stepping out of a kayak and into water); Loope v. Goodings Million Dollar Midways, Inc., 553 S.W.2d 573, 574-75 (Tenn. 1977) ("Petitioner sustained electrical shock when she touched a metal handrail while at the same time standing on wet ground, as she was preparing to enter one of the cars or cages of the midway ride. Subsequent investigation revealed that a short had occurred in the electrical circuits supplying current to the lights on the unit.").

274. See supra notes 234-35 (demonstrating disconnect between traditional justifications and modern applications).

275. See supra notes 14, 18, 232, 236 (providing cases where courts focused on particular ride features). 


\section{Blurring Lines Between Similar and Dissimilar Water Rides}

Several courts argue that the appropriate liability standard depends on the particular type of ride at issue. ${ }^{276}$ By varying the liability standard based on a ride's characteristics, courts attempt to draw lines of demarcation between rides subject to reasonable care and rides demanding heightened care. Courts sketch these dividing lines based on various ride characteristics, public policy concerns, and common carrier elements. ${ }^{277}$ But courts disagree over the characteristics and concerns that call for one liability standard instead of another. ${ }^{278}$ This disagreement has flooded water ride litigation. Courts applying a heightened standard to operators of a certain type of water ride "are just as numerous as those not requiring such, and just as diverse in their rationale[s] in arriving at their conclusions. ${ }^{279}$ But, with water rides, courts continually struggle to draw meaningful lines of demarcation because the infinite combinations of characteristics, designs, features, and risks make it impossible for courts to consistently apply the same standard to the same "types" of rides. ${ }^{280}$

276. See Chavez v. Cedar Fair, LP, No. WD 75373, 2013 Mo. App. LEXIS 843, at*13 (Mo. Ct. App. July 16, 2013) (explaining that the liability standard depended on the circumstances); Chad A. Gerardi, Note, A Tale Involving the Magic Kingdom, Pirates, and a Court's Broad Interpretation of Common Carrier Liability, 1 CHAP. L. REV. 171, 183 (1998) ("However, the majority of the rides, such as Peter Pan's Flight, It's a Small World, the Haunted Mansion and Pirates of the Caribbean, are innocuous excursions in which persons of every age may ride comfortably. An illogical result would exist if these rides are considered common carriers, while holding the park's roller coasters are not common carriers because of the perceived risks. This variety in the types of amusement rides underscores the problem with [a] broad holding that amusement park rides are per se common carriers....").

277. See supra Part III.A.1 (outlining general inconsistencies).

278. See supra notes 14-15, 221 (providing specific inconsistencies); Gerardi, supra note 276, at 176 (stating that "courts nationwide have struggled with the degree of care owed by amusement park operators" (citing Neubauer v. Disneyland, Inc. 875 F. Supp. 672, 673 (C.D. Cal. 1995))).

279. Cerola, supra note 234, at 9.

280. See Gerardi, supra note 276, at 183 (explaining that the "variety in the types" of rides makes it impossible for a broad holding about ride liability to accommodate those different risks); Deutsch v. Chubb Grp. of Ins. Cos., Civ. A. No. 95-B-331, 1995 WL 584394 (D. Colo. 1995) (white water rafting operator held not a common carrier); Avery \& Dickson, supra note 10, at 30506 ("The decision of the California Supreme Court to apply common carrier law to amusement rides and device might be the opposite end of the spectrum for the industry; placing an undue burden on owners and operators in California to achieve unrealistic expectations. The reality of the matter is that the industry is providing ride and device experiences that are unique to each rider .... The combination of ride and device types, rider decisions, operator considerations, inspections practices, oversight, and design play a role in each incident.... The industry is inviting guests to actively participate or be transported on numerous rides and devices of varying extremes. Each rider is unique and their experiences and knowledge with amusement rides and devices diverse.") (citation omitted). 
Take water slides, for example. To name just a few differences, patrons may slide through a channel on their backs, on a raft, or in a tube. Rafts and inner tubes might have nylon handles, harnesses, seatbelts, or no restraints at all. ${ }^{281}$ The water slide could be anywhere from 10-feet tall to nearly 140 -feet tall. ${ }^{282}$ Patrons might reach speeds of up to sixtyfive miles per hour ${ }^{283}$ for varying lengths of time or on slides with different designs. ${ }^{284}$ Some slides have massive water pumps that churn out thousands of gallons of water into the slide's channel on an hourly basis, ${ }^{285}$ and other slides have no water pumps at all. ${ }^{286}$ Some slides are enclosed and run underwater, while other slides are open and aboveground. $^{287}$ Even more, water slides have different twists, turns, drops, safety mechanisms, operation procedures, construction materials, wiring systems, water depths, and other unique features. And these are just a few differences between water slides! ${ }^{288}$ With just as many differences between any water-ride category, it does little good to apply the same standard to a ride based on an artificial label like "log flume" or "water rapids." After all, each amusement park intentionally designs rides that are different from those in other parks, which all but guarantees that water rides will only grow in difference. ${ }^{289}$

By trying to navigate the vast conglomerate of water-ride characteristics, courts often get distracted by a ride's complex mechanical features and overlook the core, historical justifications for

281. See Rivere v. Thunderbird, Inc., 353 So. 2d 346, 347 (La. Ct. App. 1977) (running water and no raft on slide); Rossetti v. Busch Entm't Corp., 87 F. Supp. 2d 415, 416-17 (E.D. Pa. 2000) (oversized rafts in narrow slide channel); Greenwood v. Busch Entm't Corp., 101 F. Supp. 2d 292, 293 (E.D. Pa. 2000) (slide without raft but with three-foot-deep pool as landing spot); Kyia v. Lake Compounce Theme Park, Inc., CV010807302S, 2002 WL 1949222, at *1 (Conn. Super. Ct. July 22, 2002) (slide with innertube that landed in a lake); Chavez, 2013 Mo. App. LEXIS 843, at*1-4 (raft with nylon handles that seated multiple patrons); Neubauer v. Disneyland, Inc., 875 F. Supp. 672, 673 (C.D. Cal. 1995) (larger boats that collided on the surface); Ortiz ex rel. Ortiz v. Splish Splash Adventureland, Inc., 17 Misc. 3d 1104(A), *1 (N.Y. Sup. Ct. 2007) (steep slide with no raft or innertube but patrons propelled by pressurized water jets); Austin, supra note 129 (noting sharp slides with enclosures and loops were common but dangerous).

282. See supra notes $132,139-41$ (providing specific types of ride restraints); Insane 17-Story Waterslide Coming to Schlitterbahn, Fox 4 NEWS (Nov. 19, 2013, 2:05 PM), http://fox4kc.com/ 2013/11/19/insane-17-story-waterslide-coming-to-schlitterbahn/.

283. See supra notes 8, 134, 178 (listing different speeds patrons travel on different rides).

284. See discussion supra Part II.B.2 (discussing infinite variations in ride designs).

285. See supra notes 137, 141; infra notes 326, 340, 462 (discussing differences in rides with water pumps).

286. See supra notes $125-27,132-35$ (showing differences between rides without water pumps).

287. See supra note 280.

288. See discussion supra Part II.B.2.

289. See supra notes 122, 137-43 (showing how parks strategically build unique rides); Avery \& Dickson, supra note 10, at 305-11 (noting that competition created unique rides). 
imposing common carrier liability. ${ }^{290}$ Consequently, whether a ride has, for example, a raft with nylon handles, becomes more important than a patron's inability to prevent incoming harm on a particular ride. ${ }^{291}$ More importantly, by focusing solely on the control disparity, courts risk incentivizing operators to remove safety restraints on rides in order to avoid the heightened standard.

Courts also ensure a constant stream of future litigation by applying different liability standards to different types of rides. ${ }^{292}$ Given the multitude of water-ride characteristics, parties can always find several differences between the ride at issue and some "similar" ride from another case where the court applied a reasonable care or heightened standard. ${ }^{293}$ For instance, after surveying cases where courts applied common carrier liability to operators of amusement rides with supposedly similar features, the California Supreme Court held the operator of a Disneyland roller coaster to the heightened standard because, according to the court, elevated liability balanced the profit made from transporting patrons along the ride's sharp curves and steep inclines. $^{294}$ That rationale created more confusion than clarity because whether a ride had "steep inclines" or "sharp curves" was a subjective determination that varied for every person, ride, and court. ${ }^{295}$ More concerning was that these vague descriptions focused more on a ride's

290. See Rivere v. Thunderbird, Inc., 353 So. 2d 346, 348 (La. Ct. App. 1977) (citing Givens v. De Soto Bldg. Co., 156 La. 377 (1924)) (focusing on ride appearance more than carrier similarities); Best Park \& Amusement Co. v. Rollins, 68 So. 417, 418 (Ala. 1915) (focusing on "[t]he steep inclines, sharp curves and great speed" when applying heightened standard of care to amusement park ride (quoting O’Callaghan v. Dellwood Park Co., 89 N.E. 1005, 1007 (Ill. 1909))).

291. See Chavez v. Cedar Fair, LP, No. WD75373, 2013 Mo. App. LEXIS 843, at*13-14 (Mo. Ct. App. July 16, 2013) (focusing more on the raft's specific design features than on traditional carrier rules and rationales).

292. See Stephen M. Sullivan, Note, Of Thrill Rides and Bar Fights: Gomez v. Superior Court, Delgado v. Trax Bar \& Grill, and the Expanding Duty of Care in California, 36 Sw. U. L. REV. 59, 73 (2007) ("Because of Gomez, parties must litigate the issue of what constitutes the "mode and characteristic' of the ride in addition to what is 'reasonable' in the operation of the attraction.").

293. See supra notes $122,137-43,280$ (highlighting infinite ride variations).

294. Gomez v. Superior Court, 113 P.3d 41, 45-46 (Cal. 2005).

295. See Goodfried, supra note 38 , at 22-23 ("With this decision, operators of amusement parks will lack a clear understanding of the liability for attractions other than roller coasters in their own park. The plain language of the opinion states that roller coasters and other similar attractions can be common carriers, but never defines or explains what is included in 'other dissimiliar, amusement rides.' A roller coaster is defined as a 'steep, sharply curving elevated railway with small open passenger cars that is operated at high speeds as a ride, especially in an amusement park.' The question remains whether only rides with railways and high speeds are considered similar attractions, or, whether the court considers attractions that offer similar thrills to be common carriers. Hypothetically, a large Ferris Wheel, which might be considered more prone to causing injuries than a typical roller coaster, might not be a common carrier, leaving major liability questions unanswered."); Sullivan, supra note 292 (explaining confusion over differing water ride types). 
appearance than on the traditional common carrier justifications for imposing elevated liability. ${ }^{296}$

As a result, injured patrons and ride operators cascaded into California courts to litigate the appropriate liability standard for each amusement ride - from different roller coasters ${ }^{297}$ to bumper cars in a variety of sizes $^{298}$ — based on each ride's unique characteristics. ${ }^{299}$ Additionally, there was no incentive to settle these cases because patrons wanted to broaden the application of the heightened liability standard, and ride operators wanted the narrow the standard. Nevertheless, seemingly with each district, appellate, or California Supreme Court case, courts provided inconsistent rationales and focused on distinct ride characteristics to determine the applicable liability standard for a particular ride. $^{300}$ Regrettably, this confusion and inconsistency inundates courts across the nation. ${ }^{301}$ Thus, a court's decision about the liability standard for a tall, fast, raft-based ride typically does not resolve the liability question for slides with different handles, sizes, speeds, or heights.

Ultimately, neither patrons nor ride operators can predict which liability standard and tort concepts apply to patrons' injury claims. ${ }^{302}$ In fact, with future technological advances sure to multiply the features and types of water rides ${ }^{303}$ - on top of each amusement park's goals to offer unique rides ${ }^{304}$-attempts to draw lines of demarcation along the waterride spectrum will create more confusion, encourage additional litigation,

296. See Gomez, 113 P.3d at 45-46 (Cal. 2005) (focusing on danger and not providing a clear test for common carrier application).

297. See Cerola, supra note 234 , at $8-12$ (noting confusion over roller coasters with different features).

298. See Nalwa v. Cedar Fair, LP, 290 P.3d 1158, 1160 (Cal. 2013) (applying assumption of risk doctrine to injuries from bumper cars).

299. See Gomez, 113 P.3d at 45-46; Gerardi, supra note 276, at 171 ("This standard, while simple conceptually, has proven difficult in its application. When interpreting this statute, the California courts have struggled with defining a common carrier.").

300. See Goodfried, supra note 38, at 22-23; Sullivan, supra note 292, at 73 (reviewing confusion in California over governing standards for ride operators).

301. See Gerardi, supra note 276, at 171 n.3 ("This standard, while simple conceptually, has proven difficult in its application. When interpreting this statute, the California courts have struggled with defining a common carrier.") (citing "B.E. Witkin, Summary of California Law, vol. 6, §§ 76773 (9th ed. 1988)); see also Webster v. Ebright, 4 Cal. Rptr. 2d 714 (Ct. App. 1992) (operator of horseback rides held to a duty of ordinary care); McIntyre v. Smoke Tree Ranch Stables, 23 Cal. Rptr. 339 (Ct. App. 1962) (operator of a mule train held to a duty of utmost care and diligence).

302. See Avery \& Dickson, supra note 10, at 304 (explaining confusion for industry and courts over appropriate standard and scope of liability).

303. See id. at 305-10 (noting safety features, new designs, and new features that will grow as technology advances).

304. See supra notes 17-18, 122, 137-43 (discussing one-of-a-kind rides). 
and add to the number of inconsistent standards to which ride operators are held.

3. Effect of Inconsistent Standards on the Amusement Park and WaterRide Industry

Courts crushed the amusement industry's efforts to reduce ride injuries by developing definitive industry standards. ${ }^{305}$ Amusement parks repeatedly tried to unify and streamline water-ride safety measures. $^{306}$ Parks tried to collaborate by sharing accident data and safety-test results to determine the most effective precautions. ${ }^{307}$ But it did not matter what experts agreed was the best safety measure, equipment, or procedure, because each state required operators to use or do something else. ${ }^{308}$

The optimum precaution was not always the precaution courts required. ${ }^{309}$ Some courts required less, while others required something more without explaining what more could feasibly be done to protect passengers. ${ }^{310}$ And while state legislatures and industry organizations also created a body of divergent safety requirements and laws, it was courts that drove the nail in the coffin by spawning a vast body of conflicting interpretations of organizational and legislative requirements. ${ }^{311}$ One commentator explained that inconsistent standards decreased ride safety because:

[A]cross the USA, amusement ride and device owners and operators are being subjected to varying approaches to industry safety based on state-by-state objectives and concerns. The existing standards are being interpreted and applied inconsistently as a result. Many... change based on the number of rides, employees, and/or location of the facility or temporary event. This haphazard approach does little to

305. See Avery \& Dickson, supra note 10, at 309 (noting effect of inconsistent standards on ride safety).

306. See id. at 304-05 (discussing attempts to improve safety measures derailed by inconsistent standards).

307. See id. at 305 (highlighting independent park efforts).

308. See id. at 309 (pointing out the struggle to unify ride standards).

309. See id. (noting that improved mechanical devices could not be implemented without violating the inflexible engineering standards).

310. See Gomez v. Superior Court, 113 P.3d 41, 45-48 (Cal. 2005) (providing abstract requirements of care for common carries without any technical specifications explaining how they could have exercised more care).

311. See Avery \& Dickson, supra note 10, at 306-08 (identifying the magnified problem with legislative involvement because having so many different agencies effectively dilutes industry safety efforts as well as industry voice). 
assist in the unification of safety efforts industry wide and potentially inhibits the closure of any gaps realized from previous incidents or situations.

Furthermore, due to these inconsistent standards, there are now "a large faction" of ride operators "who are simply unaware, choose to ignore, or do not have to abide by" the various legal liability standards and safety requirements. ${ }^{313}$ Thus, courts' attempts to draw lines in the sand do little to promote safety but do much to increase the risk of patron injury.

\section{B. A Flood of Flaws that Flow from the Heightened Standard}

This section compares the heightened standard of care with the reasonable care standard. It concludes that the reasonable care standard: (1) places liability on the actor who is best able to control the risk of injury; (2) prevents unlimited liability by providing clear guidelines; and (3) decreases prejudice. ${ }^{314}$

\section{Liability for Controllable Risks}

The foundational common carrier rationales support the application of a reasonable care standard to water-ride operators because patrons have significant control and freedom on water rides. Originally, courts created the heightened standard to protect passengers in horse-drawn stagecoaches and early trains ${ }^{315}$ because those passengers could neither prevent nor cause harm. ${ }^{316}$ But water-ride patrons are often free to jump,

\footnotetext{
312. Id. at 310 .

313. Id. at 309 .

314. See Union Traction Co. of Ind. v. Berry, 121 N.E. 655, 658 (Ind. 1919) (arguing jury instruction with heightened standard prejudices the defendant); Houston \& T.C. Ry. Co. v. Keeling, 120 S.W. 847, 848 (Tex. 1909) (noting highest degree of care jury instruction by itself is inadequate because "attempting to define the carrier's duty only by the use of an adjective, are not apt to convey to the minds of jurors any very definite conception of the subject.").

315. See Kaczorowski, supra note 42, at 1164-65 (discussing the disjunction between different time periods and fault analysis); Gerardi, supra note 276, at 184 ("California's common carrier statute was enacted in 1872. At that time, the primary sources of transportation were horses, stagecoaches, steamboats, and railways. Legislation was enacted to regulate the new transportation era. Arguably, the intent was to provide safety in transportation, not entertainment. After all, the first roller coaster in the United States was not in operation until 1884. The first Ferris wheel was introduced in Chicago in 1893. California's first amusement park opened for business at Santa Cruz in 1904.").

316. See Kaczorowski, supra note 42, at 1158 (noting passengers were helpless and unable to anticipate or prevent accidents while being transported by a carrier).
} 
swim, or move around. ${ }^{317}$ And unlike a train or stagecoach passenger, a patron on a water slide does not ride in an enclosed vehicle that the operator drives and controls. ${ }^{318}$

Moreover, the operator might inspect the slide and offer warnings, but the operator cannot stop a patron from grabbing hold of the side and intentionally jumping out of the slide. Likewise, a ride operator cannot stop one patron from pulling on the side of an inflatable raft to overturn it. Ultimately, with patrons having so much freedom and control, applying the heightened standard forces a ride operator to bear the cost of injuries that are caused by a patron's irresponsible behavior. ${ }^{319}$ That result is at odds with courts' justification for refusing to apply strict liability to passenger carriers - to incentivize cautious passenger behavior by limiting the heightened standard to cases where patrons cannot protect themselves. ${ }^{320}$

Furthermore, a ride operator's conduct is merely one of several industry-related factors that may contribute to a patron's injury. ${ }^{321}$ For example, a patron's injury might be the result of a design flaw, construction error, installation mistake, ride-operator error, unsafe condition on the premises, the patron's own conduct, or a fellow patron's conduct - to name a few potential causes. ${ }^{322}$ In theory, an operator error, such as failing to secure a lap bar, should be easily distinguished from a construction error, such as failing to waterproof a section of electrical conduit. But, in practice, courts blur these different factors and apply a broad interpretation of operation. ${ }^{323}$

So, while operation may be defined as 'running' a ride, there is no bright line test for separating non-operational activities. ${ }^{324}$ Moreover,

317. See Beard, supra note 253 (noting freedom to move on water slides).

318. See id.; see also supra note 280.

319. See Beard, supra note 253 (connecting heightened operator liability with decreased patron caution).

320. See Conver v. EKH Co., No. 02AP-1307, 2003 WL 22176815, at*5-9 (Ohio Ct. App. Sept. 23, 2003) (connecting precaution and prevention in a case involving injury to limousine passengers)

321. See Avery \& Dickson, supra note 10, at 305-06 (pointing to multitude of causes in ride injuries).

322. See id. (noting that operation is just one aspect of causal factors for patron injuries, and listing ride and device types, rider decisions, operator considerations, inspection practices, oversight, and design as potential causes of a patron's injury).

323. See Beard, supra note 253 (highlighting overlooked differences between negligent construction and negligent operation).

324. See Chavez v. Cedar Fair, LP, No. WD 75373, 2013 Mo. App. LEXIS 843, *13-18 (Mo. Ct. App. July 16, 2013) (conflating ride operation with ride construction by imposing heightened liability based on the design and construction of the rafts' safety features, but largely ignoring how 
this blurring makes the operator liable for injuries caused by construction errors or design flaws - despite the operator's minimal ability to control those problems. ${ }^{325}$ In fact, a ride operator may perform daily test runs and inspections, yet still be liable for injuries caused by a latent manufacturing defect in, for example, a computer chip or valve pump. ${ }^{326}$ And while operators are expected to inspect and maintain rides, operators are not experts in the computer programming or mechanics of each water-ride component. ${ }^{327}$

Furthermore, unlike the early 1800 s when common carriers often owned, built, and maintained their own stagecoaches, ${ }^{328}$ modern rides are increasingly complex. ${ }^{329}$ Requiring operators to inspect each nut and bolt, along with having expertise for each unique ride component, creates a standard of care that is impossible to satisfy. ${ }^{330}$

Despite operators' limited control over the potential causes of an accident, several courts single out ride operators when applying the heightened standard by only applying a reasonable care standard to the other potentially culpable actors. ${ }^{331}$ Thus, even when a patron's injury is clearly the result of a construction error, patrons are incentivized to craft

careful the ride operator was in actually using those devices), rev'd, No. SC93658, 2014 Mo. LEXIS 220 at $* 1$ (Mo. Nov. 12, 2014).

325. See Beard, supra note 253 (highlighting overlooked differences between negligent construction and negligent operation in court's analysis and decisions); Avery \& Dickson, supra note 10, at 305-06 (expressing concern over unachievable precaution requirement).

326. See Avery \& Dickson, supra note 10, at 305-06, 311-12 (explaining operators' limited ability to prevent accidents where there is a flaw in the design).

327. See id.

328. See Webb, supra note 42, at 1086-87 (discussing stagecoach accidents as an origin of the res ipsa loquitor doctrine).

329. See Avery \& Dickson, supra note 10, at 305-06 (pointing to multitude of causes in ride injuries).

330. See id. at 305-06 (arguing that effect of carrier liability on ride operators is "placing an undue burden on owners and operators in California to achieve unrealistic expectations. The reality of the matter is that the industry is providing ride and device experiences that are unique to each rider. As a result, the industry and external agencies must contend with the fact that the combination of ride and device types, rider decisions, operator considerations, inspections practices, oversight, and design play a role in each incident.").

331. See discussion supra Part III.B.1. For an in depth examination of the theoretical applications of these standards, see James Fleming Jr., Functions of Judge and Jury in Negligence Cases, 58 Yale L.J. 667 (1949); Steven Hetcher, The Jury's Out: Social Norms' Misunderstood Role in Negligence Law, 91 GeO. L.J. 633, 633-34 (2003); Stephen G. Gilles, On Determining Negligence: Hand Formula Balancing, the Reasonable Person Standard, and the Jury, 54 VAND. L. REV. 813, 814-15 (2001); Richard W. Wright, Hand, Posner, and the Myth of the "Hand Formula", 4 Theoretical Inquiries L. 145, 148 (2003); Ashley M. Votruba, Comment, Will the Real Reasonable Person Please Stand Up? Using Psychology to Better Understand How Juries Interpret and Apply the Reasonable Person Standard, 45 ARIZ. ST. L.J. 703, 704-05 (2013); Alan D. Miller \& Ronen Perry, The Reasonable Person, 87 N.Y.U. L. REV. 323, 333-34 (2012); Zipursky, supra note 60, at 2015-17. 
their pleadings to shift the blame to the ride operator, as the heightened standard increases the likely settlement value or trial award. ${ }^{332}$ Additionally, even if the construction company is joined to the case, the operator is still disadvantaged because the jury instructions will require a higher level of caution from the operator and, thereby, suggest to the jurors that the construction company has less responsibility for the construction error. As a result, liability falls on the ride operator, who is the party least capable of preventing the harm, and the construction company - whose engineers, experiences, and experts place it in the best position to detect and correct the error-avoids responsibility for its actions. $^{333}$

To make matters worse, ride operators are often prohibited by various standards and regulations "from making design changes or modifications[,] even when they may enhance the ride's safety." ${ }^{334}$ Given that most safety issues stem from design and construction defects, ${ }^{335}$ it makes little sense to impose heightened liability on a ride operator and, consequently, place the full cost of a defect on an operator who is prohibited from making any repairs.

Ride operators may also be punished twice when held to a heightened standard. For example, in Chavez, the Missouri Court of Appeals upheld a verdict that effectively required the water-slide operator to install a different type of safety restraint in the rafts in order to satisfy the heightened standard of care. ${ }^{336}$ This creates a lose-lose scenario because, on one hand, failing to alter the raft restraints exposes the slide operator to significant liability from any future patron injuries. $^{337}$ On the other hand, by changing the restraints, the slide

332. See Beard, supra note 253 (explaining how patrons will target operators for large verdicts); Votruba, supra note 331 , at 714 (noting the effect on the settlement process when parties realize jurors are more likely to find in their favor based on a prejudicial instruction).

333. See Kaczorowski, supra note 42, at 1199 (explaining common carrier approach to "culpability and causation: Whoever was in the best position to avoid an injury was liable for it.").

334. Avery \& Dickson, supra note 10, at 311.

335. See id. (noting that most early safety defects stemmed from design defects).

336. Chavez v. Cedar Fair, LP, No. WD 75373, 2013 Mo. App. LEXIS 843, at*1-2, *8 (Mo. Ct. App. July 16, 2013), rev'd, No. SC93658, 2014 Mo. LEXIS 220, at *26 (Mo. Nov. 12, 2014).

337. See Avery \& Dickson, supra note 10, at 304 ("Essentially, this means that the patron is provided with a level of protection; however, the protection is commonly experienced after an incident on an amusement ride or device. Regardless if a state or entity has adopted the standards whole or in part, the organization could be held to design and manufacture, testing, operation, maintenance, inspection, and quality assurance practices within the standards.... ASTM F 24 standards are still evolving in an effort to address the complexity and ever-changing landscape of the amusement ride and device industry."); Cereola \& Foucar-Szocki, supra note 28, at 51-52 ("[S]tate laws and regulations constitute the floor or minimum standard of conduct for determining the duty of care owed patrons. It is well settled tort law that compliance with governmental laws and 
operator is likely to violate either state regulations or standards enforced by ride-inspection specialists because of the strict requirements and restrictions on installing different restraints in a water-slide raft. ${ }^{338}$ However, in addition to resolving this dilemma by reversing the appellate court, the Missouri Supreme Court also pointed out that looser straps (the type that the jury found to be unsafe) are essential on steep raft rides because patrons restrained by buckles or bars could drown if the raft flipped over. ${ }^{339}$ That comment is significant because it shows how the heightened standard may force operators to replace safe devices (loose straps) with dangerous devices (bars or buckles) in order to avoid future liability.

In comparison, the reasonable care standard does not require ride operators to violate safety regulations in order to avoid liability for construction or design defects. ${ }^{340}$ For example, in one New York case, an injured patron sued a ride operator after a defective water pump malfunctioned and shot the patron onto the ground. ${ }^{341}$ The operator provided evidence of thorough, daily pump inspections, and the court quickly found that the latent pump defect was a manufacturer's error for which the ride operator was not liable. ${ }^{342}$ As the court noted, while operators have a duty to reasonably inspect their rides, "reasonability" embodies the understanding that even the most thorough inspections cannot identify every potential flaw. ${ }^{343}$ The outcome in that case is just one example of how the reasonable care standard ensures that liability does not extend beyond the risks that the actor can control.

regulations does not automatically equate to the level of care required of a "reasonably prudent person"... [h]owever, failure to comply... would most certainly be strong evidence of negligence.").

338. See ASTM, Standard Practice for Classification, Design, Manufacture, Construction, and Operation of Water Slide Systems, in ASTM F2376-2006: STANDARD PRACTICE FOR DESIGN OF AMUSEMENT RIDES AND DEVICES 1549-52 (2006), available at https://law.resource.org/ pub/us/code/ibr/astm.f2376.2006.pdf (providing over fifty of the premier standard-setting organization's requirements that apply to modification of raft restraints).

339. Chavez, 2014 Mo. LEXIS 220, at*1.

340. Ortiz v. Splish Splash at Adventureland, Inc., No. 10045/05, at 3 (N.Y. Sup. Ct. Sept. 17, 2007) (pointing out that ride operator had a record of performed inspections for water pressure defects and, with nothing discovered, was not liable anyway because that would be a design defect instead of operational cause).

341. See id. (alleging operator failed to locate error that shot patron out of slide).

342. Id.

343. See id. (finding that prior inspections satisfied the operator's duty of reasonable care, even though the operator did not discover the product defect); Avery \& Dickson, supra note 10, at 305 (noting it is an impossible standard to require operators to identify every potential flaw). 


\section{Avoiding Infinite Operator Liability by Adopting a Clear Standard}

The heightened standard's ambiguity creates conflict with the foundational goal of early carrier jurisprudence by transforming operators into "insurers of their passengers" safety." 344 This "insurer effect" is common today because courts have failed to articulate a concrete test to prevent the heightened standard from having a strict liability effect. ${ }^{345}$ In addition, it is unclear where reasonable care ends and heightened care begins. ${ }^{346}$ Does a ride operator satisfy the heightened duty by inspecting a ride six times a day, or do six inspections only equate to reasonable care? If six inspections are reasonable, then would seven inspections satisfy the heightened duty? Or does the heightened duty require twelve inspections? There is no answer to those questions because there is no specific legal test to distinguish reasonable care from the heightened standard of care.

Nevertheless, patrons insist that reasonable care permits fewer precautions than under a heightened standard of care. ${ }^{347}$ Certainly, courts phrase the scope of the heightened standard differently by using labels like "the utmost degree of care of very prudent persons," "the highest degree of care," "the highest degree of care that is possible to human foresight and prudence," "the greatest possible care and diligence," and with other similar descriptions. ${ }^{348}$ Yet the precise meaning of those phrases is unknown. ${ }^{349}$ And because reasonable care demands precautions that are proportionate to an activity's risks, phrases like the

344. Gomez v. Superior Court, 113 P.3d 41, 44 (Cal. 2005) (quoting Lopez v. S. Cal. Rapid Transit Dist., 710 P.2d 907 (Cal. 1985)).

345. See Westerbeke, supra note 29, at $14 \mathrm{n} .76$ (noting that jurors are unlikely to measure the limits of "the highest degree of care," but most people can grasp the meaning of "reasonable" in determining if a person took sufficient precaution based on foreseeable risks); Westerbeke \& McAllister, supra note 61, at 1065 (explaining that phrases like "the highest degree of care" are frequently applied but rarely defined with a measurable test).

346. See Westerbeke, supra note 29, at $14 \mathrm{n} .76$ (asserting that the heightened standard has no measurable dividing line, which makes it more likely that jurors will effectively apply a strict liability approach).

347. See, e.g., id. (exploring the Kansas Supreme Court's concern in a firearm entrustment case that applying a reasonable care standard would not require strong enough precautions to prevent injuries from shootings); Nalwa v. Cedar Fair, L.P., 290 P.3d 1158, 1167 (Cal. 2012) (involving patron alleging highest degree of care breached because bumper car sat a hair of an angle too high, which would have been a permissible angle under a reasonable care standard).

348. See Chavez v. Cedar Fair, LP, No. WD 75373, 2013 Mo. App. LEXIS 843, at*10-11 (Mo. Ct. App. July 16, 2013), rev'd, No. SC93658, 2014 Mo. LEXIS 220 (Mo. Nov. 12, 2014) (offering various descriptions); Fredericks v. N. Cent. R.R. Co., 27 A. 689, 691 (Penn. 1893) (providing additional descriptions).

349. See Beard, supra note 253 (pointing out that heightened standard is unclear and demands unreasonable precautions). 
"the highest degree of care" must require a ride operator to either take unreasonable precautions or somehow foresee risks that are invisible to a reasonable operator. ${ }^{350}$ In reality, the lack of a quantifiable or bright line distinction between the standards makes the heightened standard a proxy for strict liability because there is always something more that an operator could have done to prevent an injury-making hindsight the focus, instead of what the operator could control or foresee at the time. ${ }^{351}$

\section{a. The Ever-Moving Ceiling}

Patrons use the heightened standard's ambiguity to argue that ride operators just barely missed the mark. In one Texas case, the court suggested that an operator could have breached the highest degree of care standard-despite exercising ordinary care, using a top-of-the-line engine guard to prevent sparks from escaping and causing damage, "carefully and skillfully handl[ing]" the device, and performing proper inspections. ${ }^{352}$ The court speculated that there "might have" been a better guard, and that better guard still "might not be the safest," so the possibility that the operator could have done "something more" meant that the operator could still be liable. ${ }^{353}$ However, the court neither determined if a better guard actually existed, nor did the court clarify how much better a guard or alternative precaution needed to be in order to satisfy the heightened standard. ${ }^{354}$ Hence, the patrons were free to hypothesize to a jury about microscopic changes the operators could have made that might have prevented an injury-maybe. Effectively, patrons could allege that an operator's extensive precautions came close, but there was still no cigar because whatever an operator did only constituted reasonable care, and the highest degree of care required the

350. See Union Traction Co. of Ind. v. Berry, 121 N.E. 655, 658 (Ind. 1919) ("If the words 'highest degree of care practical' are given any significance at all, they must mean, as applied to this case, that the conductor was required to possess and exercise something more than ordinary judgment, ordinary foresight, ordinary prudence, and ordinary care to prevent the injury.").

351. See Manus v. Trans States Airlines, Inc., 835 N.E.2d 70, 76 (Ill. App. Ct. 2005) (Goldenhersh, J., concurring) (providing argument from operator that "this is essentially strict liability, because the jury could conclude that if there were anything more that defendant could have done to prevent plaintiff's injury, then defendant has breached a duty").

352. St. Louis Sw. Ry. Co. v. Parks, 76 S.W. 740, 741-43 (Tex. 1903).

353. See id. (noting that a good guard may not be good enough to avoid liability).

354. See id. (telling the operators to use a better guard without instructing the operators where to find one or if a better guard even existed). 
operator to go one step further or to use some imagined alternative to satisfy the heightened standard. ${ }^{355}$

Similarly, ride operators that comply with every state and industry regulation may still be required to do something more to satisfy the heightened standard. ${ }^{356}$ Indeed, with pure conjecture, patrons can always tell the jury that the highest degree of care requires one more inspection, one size bigger font on a warning sign, one more nylon strap, one more safety test, one more bolt, one less drop, one less inch of water, or one less twist. ${ }^{357}$

At some point, no additional precautions will prevent injury without eliminating the purpose of the water ride. ${ }^{358}$ A central purpose of the heightened standard is to reduce the risk of injury by requiring precautions that are consistent with the "character" and "practical operation" of a water ride. ${ }^{359}$ Unlike strict liability, which discourages the continuation of an activity altogether, the heightened standard is still supposed to encourage ride operation, just in some safer manner. ${ }^{360}$ So, in theory, operators should not be required to take precautions that alter "the basic character of the activity." 361 However, just like the phrase "highest degree of care," there is no test to determine when a ride precaution crosses this "basic character" line. Absent a measurable line, patrons can side step the limitation by arguing for small changes that gradually raise the required amount or type of precautions. With those gradual increases, ride operators are forced to implement impractical, inefficient, and wasteful measures ${ }^{362}$ that effectively transform operators into "insurers of their passengers' safety." 363

355. See, e.g., Nalwa v. Cedar Fair, L.P., 290 P.3d 1158, 1163 (Cal. 2012) (pointing to degree of incline on bumper car alignment as the reason for the patron's injury).

356. See Cereola \& Foucar-Szocki, supra note 28, at 51-52 (explaining that operators can meet every state and industry standard yet still be found liable for not doing something more).

357. See Union Traction Co. of Ind. v. Berry, 124 N.E. 737, 738-39 (Ind. 1919) (pointing out that operators must be able to possess more-than-ordinary foresight and criticizing that idea as an ambiguous standard that allows infinite liability); Manus v. Trans States Airlines, Inc., 835 N.E.2d 70, 76 (Ill. App. Ct. 2005) (Goldenhersh, J., concurring) (noting that a jury, in hindsight, will always find that there was something more an operator could have done to avoid the accident).

358. Mosby v. Greyhound Lines, Inc., No. 06-13157, 2007 WL 4572049, at *6 (E.D. Mich. Dec. 27, 2007) (discussing practical limitations).

359. Gomez v. Superior Court, 113 P.3d 41, 44 (Cal. 2005) (explaining precaution-based goal of heightened liability).

360. See John L. Diamond, Lawrence C. Levine \& Anita Bernstein, Understanding TORTS 59-60 (4th ed. 2010) (explaining that the goal of strict liability is to make the cost of an activity so high as to discourage the particular method of conducting that action).

361. Nalwa v. Cedar Fair, L.P., 290 P.3d 1158, 1163 (Cal. 2012).

362. See Avery \& Dickson, supra note 10, at 306 (requiring unachievable precautions).

363. Gomez, 113 P.3d at 44. 
The reasonable care standard, on the other hand, is a clearer standard that both prevents open-ended liability and also requires operators of higher risk rides to take increased precautions. Specifically, reasonable care means that operators must take precautions commensurate with the dangers of a particular ride under all the circumstances. ${ }^{364}$ At its core, the heightened standard of care "is simply another way to describe a reasonable care standard in which the heightened dangerousness of the [water ride] requires commensurately heightened precautions in order to satisfy reasonable care under all the circumstances." care is not a "lesser duty," 366 as a reasonable operator of a high-risk ride would always exercise heightened care. ${ }^{367}$ Even where there is a low probability of injury, the reasonable operator would still undertake strong precaution where the injury would be severe. ${ }^{368}$ In other words, there is only a semantic difference between "reasonable care" and "the highest

364. W. Page Keeton et al., Prosser and Keeton on the Law of Torts § 34, at 208-09 (5th ed. 1984).

365. See Westerbeke \& McAllister, supra note 61, at 1064-65 (highlighting how reasonable care already achieves heightened precautions because caution must be commensurate with risk).

366. Gomez, 113 P.3d at 48; see Smith v. O’Donnell, 12 P.2d 933, 935 (Cal. 1932).

367. See E. R., Carriers - Liability of Elevator Operator, 4 TEX. L. REv. 247 (1926) (“[T]here is no difference between the two rules of care, and the classification of degrees of care is merely an attempt at saying that the precaution required in every case is dependent on the dangers involved."); Fleming Jr., supra note 331, at 678; DIAMOND ET AL., supra note 360, at 59-60 (illustrating why reasonable care requires extreme care for a roller coaster ride); Westerbeke, supra note 29, at 14 (pointing out that the jury is more likely to understand and correctly apply a reasonable care standard because reasonability is a common, familiar concept, while jurors lack a common understanding of a "highest degree of care" standard); Denver \& Rio Grande R.R. Co. v. Peterson, 69 P. 578, 581 (Colo. 1902) (explaining that degrees of negligence and sliding scales of duty create confusion because the duty is the same regardless of the term used); Mosby v. Greyhound Lines, Inc., No. 0613157, 2007 WL 4572049, at *7 (E.D. Mich. Dec. 27, 2007) (“The Tennessee cases demonstrate that their application of the 'heightened' standard is nothing more than an acknowledgment of the increased risks associated with carriage for hire and the passengers' reliance on the common carriers for their safety.").

368. See DiAmond ET AL., supra note 360, at 59-60 \& n.60 (“" [R]easonable care [always requires] "care appropriate for the circumstances of the case."' (emphasis omitted) (quoting Felgner v. Anderson, 133 N.W.2d 136, 140 (Mich. 1965)); Gerardi, supra note 276, at 184-85 (citation omitted) ("Ordinary negligence concepts protect the patrons of roller coasters and similar 'high risk' amusement rides. There is no need to distort the meaning of 'common carrier' to reach such a result. Indeed, the common law recognizes that an operator's duty must be in proportion to the apparent risk. As the risk increases, so does the duty of care.... The odds may be a thousand to one that no train will arrive at the very moment that an automobile is crossing a rail way track, but the risk of death is nevertheless sufficiently serious to require the driver to look for the train and the train to signal the approach.... The duty of care will vary according to the risks inherent in a particular amusement park ride. Operators of such rides will be held liable accordingly.”). 
degree of care." ${ }^{369}$ But it is a semantic difference that creates limitless liability by misleading jurors and confusing courts. ${ }^{370}$

Instead of confusion, reasonable care creates consistency in the law by providing courts and juries with a common measuring stickprecaution in proportion to risk - to determine the scope of an operator's duty. $^{371}$ That measuring stick produces more efficient and effective safeguards for water ride patrons because the proportionality requirement filters out impractical precautions. ${ }^{372}$ As a result, the proportionality requirement achieves the goal of early common carrier jurisprudence by encouraging precautions that are "consistent with the character and... practical operation" of the particular water ride. ${ }^{373}$ By their inherent character, water rides are neither comfortable nor uneventful. ${ }^{374}$ Patrons not only understand that water rides come with injury risks - patrons pay good money for bigger, faster, and scarier water rides. ${ }^{375}$ So, while a ride operator could eliminate the risk of drowning by draining the water, that precaution would be inconsistent with practical operation of the ride. ${ }^{376}$

369. See DIAMOND ET AL., supra note 360, at 59 (explaining in all cases, the standard of care is reasonableness; only the amount of care changes based upon the circumstances).

370. See supra note 367 (pointing out risk for jury prejudice when applying heightened standard).

371. See supra notes 365, 367-68 (linking tradition and clarity to use of reasonable care standard).

372. See Mosby, 2007 WL 4572049, at *4 ("The law only requires of it all those things necessary for the safety of the passenger that are reasonable and consistent with the business of the carrier, and proper to the means of conveyance employed by him to be provided, that the highest degree of practical care and diligence and skill shall be adopted that is consistent with the mode of conveyance used, and that will not render its use impractical and inef[f]icient for it[s] intended purposes." (emphasis omitted) (quoting Nashville R.R. v. Howard, 78 S.W. 1098, 1103 (Tenn. 1904))).

373. Lopez v. S. Cal. Rapid Transit Dist., 710 P.2d 907, 909 (Cal. 1985).

374. See Lamb v. B \& B Amusements Corp., 869 P.2d 926, 930-31 (Utah 1993) ("The heightened standard of care required of common carriers is predicated on the principle that '[p]ersons using ordinary transportation devices, such as elevators and buses, normally expect to be carried safely, securely, and without incident to their destination.' . . . Persons who use amusement rides ... [must] be aware of their own physical abilities and limitations and exercise some judgment as to their ability to endure the physical and mental stresses encountered on various rides."); Harlan v. Six Flags Over Ga., Inc., 297 S.E.2d 468, 469 (Ga. 1982) (explaining that amusement rides are not designed to provide comfortable transportation, and patrons expect thrills, drops, bumps, and high speeds); Goodfried, supra note 38, at 11 ("[T] he purpose of thrill rides is to frighten and surprise the rider by utilizing means that present the impression of inherent danger. . . . [A]nd passengers choose these rides for exactly this reason. Some may argue that thrill ride passengers seek imagined danger, rather than real danger. ... [But] passengers are not watching a movie about roller coasters; rather, they are on the roller coaster. Imagined danger does not exist when a passenger is plummeting 200 feet and speeding through extremely tight twists and turns at velocities exceeding 100 miles an hour.").

375. See Lamb, 869 P.2d at 930-31.

376. See Mosby, 2007 WL 4572049, at *4-5 ("[T]he practical difficulties would be considerable, and in cases of collision or other accident the dangers of having the windows 
Yet that type of precaution is what emanates from the heightened standard - a standard that "poses the very real threat of eliminating" water rides altogether. ${ }^{377}$

Reasonable care balances patrons' expected risks with an operator's extensive caution. ${ }^{378}$ That does not give carte blanche for ride operators to ignore serious risks; but, unlike the heightened standard of care, ${ }^{379}$ reasonable care does not require operators choose between shutting down the ride and removing the features that patrons crave and pay to experience. ${ }^{380}$ Thus, it may be reasonable to drop riders at 60 miles-perhour from a 100 -foot-tall platform. ${ }^{381}$ But, given the proportionality requirement, a reasonable ride operator must protect ignorant riders and vulnerable children by applying height restrictions and warning patrons against hidden dangers. ${ }^{382}$ And with more frequent or severe patron injuries, ride operators must make adjustments and demonstrate a high level of precaution in order to satisfy the reasonable care standard. ${ }^{383}$

A ride operator is unlikely to prevail after failing to lock the harness for a roller-coaster patron who then fell out during the ride. ${ }^{384}$ Likewise, where multiple patrons on a water ride are injured in a similar way, such as by being forcefully slammed into the same spot on a large water slide, the operator must show specific, responsive precautions designed to prevent a similar, subsequent accident. And with each additional injury, the slide operator must show increased precautions to demonstrate reasonable care in light of the increased risk of harm. ${ }^{385}$ So, far from

effectually barred might be far worse than the danger of injury from an occasional missile.") (quoting Knoxville Cab Co. v. Miller, 138 S.W.2d 428 (Tenn. 1940).

377. Sullivan, supra note 292, at 70 (quoting Gomez v. Superior Court, 113 P.3d 41, 56 (Cal. 2005) (Chin, J., dissenting)).

378. See Lamb, 869 P.2d at 931 (offering different expectations on bus than ride).

379. See Gomez, 113 P.3d at 45-46; Webb, supra note 42, at 1087.

380. See Mosby, 2007 WL 4572049, at *5 (showing how reasonable care creates a meaningful liability limit).

381. See Nalwa v. Cedar Fair, L.P., 290 P.3d 1158, 1160 (Cal. 2012) (linking reasonability with patrons' expectations).

382. See Mosby, 2007 WL 4572049, at *4-5 (showing how reasonable care creates a meaningful liability limit).

383. See Bibeau v. Fred W. Pearce Corp., 217 N.W. 374, 375-76 (Minn. 1928) ("The evidence would support a finding of the jury that the passenger experienced an unusually violent jerk which caused her injuries. One would hardly suppose it possible for defendant to continue the rollercoaster business if such accidents were ordinary occurrences.").

384. See id. (reasoning that no patrons would attend amusement parks if injuries were common expectations, and arguing that it would be hard to show it is reasonable to leave a harness unlocked on a roller coaster).

385. See Frederick v. Detroit, Dep’t of St. Ry., 121 N.W.2d 918, 920-21 (Mich. 1963) (noting that, depending on the circumstances, greater care may be required). 
being a toothless standard, reasonable care is flexible and demands that ride operators take serious precautions to protect patrons.

\section{b. Baseline Consistency and Flexibility}

The proportionality requirement also remedies the patchwork of inconsistent liability standards by creating a baseline duty requirement. ${ }^{386}$ Operators do not have to guess, or litigate to discover, what "the highest degree of care" requires because all operators, regardless of the infinite ride variations, must exercise caution in proportion to the ride's unique risks. ${ }^{387}$ That increased predictability results in increased operator compliance, which "significantly reduce[s] the likelihood of patron injuries or deaths." 388 Further, patrons will not suddenly start losing at trial, as proven by plaintiffs who still win after an appellate court orders a retrial with a reasonable care instruction instead of the heightened standard from the first trial. ${ }^{389}$

Moreover, reasonable care is consistent, yet flexible. ${ }^{390}$ Reasonability always requires care commensurate with risks, but those risks vary based on the circumstances. ${ }^{391}$ Water rides illustrate the need

386. See Avery \& Dickson, supra note 10, at 310-11 (necessitating limitations and requiring flexibility because of ride characteristics); Cereola \& Foucar-Szocki, supra note 28, at 51-52 (explaining role of state law and reasonable care floor - baseline rules promote increased safety).

387. See supra notes 26-31, 364-65, 367-68 (focusing on reasonable care's flexible, predictable formula).

388. See Avery \& Dickson, supra note 10, at 310-11 (noting importance of equal, baseline standard "It is imperative that every park or mobile ride or device operator, regardless of size, should have to adhere to the same standards.... these standards could significantly reduce the likelihood of patron injuries or death").

389. Geri L. Dreiling, Helicopter Crash Case Gets \$21M Verdict On Second Try, MissouRI LAWYERS WEEKLY (June 18, 2001), http://www.grgpc.com/News-PDFs/grg16.pdf (involving plaintiff who won on a retrial after the standard of care was switched from the heightened standard to reasonable care).

390. DiAmOND ET AL, supra note 360, at $60 \&$ n.60 (quoting Bethel v. New York City Transit Auth., 703 N.E.2d 1214, 1217 (N.Y. 1998)) (Thus, a "single, reasonable person standard is sufficiently flexible by itself to permit courts and juries to take into account the ultrahazardous nature of a tortfeasor's activity."); Frederick, 121 N.W.2d at 921 (internal citation omitted) ("The common law standard of reasonable care is constant although it "may require an infinite variety of precautions, or acts of care, depending upon the circumstances, and it is primarily for the jury to say just what precautions were appropriate to the danger apparent in the case at hand."'); Mosby v. Greyhound Lines, Inc., No. 06-13157, 2007 WL 4572049, at *6 (E.D. Mich. Dec. 27, 2007) (internal citation omitted) (noting that reasonable care is flexible in requiring that precaution match the risks, and also pointing out that "common carriers are not insurers of their passengers' safety;" so, courts "have consistently recognized that bus drivers, may as a general rule, anticipate that passengers will be aware of that fact and may start their bus in a normal motion before all the passengers are seated").

391. See supra notes 26-31, 364-65, 367-68 (providing formula for reasonable care that demands precaution proportionate to risk). 
for a flexible standard because no two rides are the same. ${ }^{392}$ Even more, "the combination of ride and device types, rider decisions, operator considerations, inspections practices, oversight, and design play a role in each incident.... Each rider is unique and their experiences and knowledge ... diverse.",393

A water slide might have a particular drop that can jar patrons who fail to hold on tightly to the raft's safety straps. Reasonable care requires an operator to guard against that unique risk by, for example, warning patrons about the drop. Conversely, two patrons racing in kayaks might get injured after trying to flip each other over. In these cases, a heightened standard ignores the patrons' role in the accident and, instead, fixates on the operator's failure to do 'something' more-even when more warnings and precautions will not stop patrons from acting irresponsibly. ${ }^{394}$

Furthermore, the heightened standard cannot accommodate water rides with multiple components. For instance, Big Surf Waterpark has a ride with a gentle slide that sits close to the ground, but stairs on the other side of the ride lead to an extreme slide called "Fast and Furious" that stands several stories tall. ${ }^{395}$ The abstract nature of the heightened standard makes it impossible to determine with any consistency what constitutes the "highest degree of care" on one slide versus another. While reasonable care is not a mathematical measurement, courts and juries are more likely to share a common understanding and measurement of what is "reasonable" based on the apparent risks for patrons on the individual slides. ${ }^{396}$

\section{Jury Prejudice}

Third, the heightened standard prejudices juries against ride operators. ${ }^{397}$ When courts apply the heightened standard, the jury instructions do not instruct jurors because jurors are left to wonder about

\footnotetext{
392. See supra notes $17-18,122,137-43$ (describing how each ride is unique).

393. Avery \& Dickson, supra note 10 , at 306.

394. See Goodfried, supra note 38 , at 28 (pointing out that the heightened standard shifts responsibility onto ride operators for patrons' reckless conduct that operators are helpless to prevent).

395. See Syrett \& Wood, supra note 8 (describing "[t]he Rapids at Big Surf, a slide that lets you choose your own adventure: fast and furious from the top, or start closer to the ground for a gentler ride into the catch pool").

396. See Goodfried, supra note 38, at 28 (calling for the court to adopt a flexible standard because the common-carrier approach places near-exclusive fault onto innocent ride operators).

397. See discussion, supra Part III.B.2.a.
} 
the meaning of phrases like "the utmost care." Regardless of the jurors" confusion over the heightened standard's abstract requirements, judges are often barred from answering questions that clarify the jury instruction. ${ }^{398}$

But wait, there is more. The heightened standard comes with several emphatic descriptions - from doing "everything possible to provide for" patrons' safety ${ }^{399}$ to the duty to exercise "the highest degree of care" 400 filled with loaded words that set the operator's duty at unreachable heights. ${ }^{401}$ With an arsenal of flowery rhetoric, it is no surprise that jurors frequently misunderstand the heightened standard and treat the duty like a strict liability standard. ${ }^{402}$

Furthermore, those emphatic statements effectively negate any limitations on the operator's duty because the jury instructions do not explain how to balance the "more than reasonable care" 403 requirement with the "operators are not insurers" limitation. ${ }^{404}$ As a result, jurors assume that operators are liable because "virtually every accident could be avoided if the [operator] acted differently in some way."

398. See Votruba, supra note 331, at 705 (explaining that in some states, the judge is even barred from answering clarification questions about the jury instructions posed by the jury during deliberations).

399. See supra note 60 (providing various ways to describe the heightened standard).

400. See Hetcher, supra note 331, at 640 (discussing application); see also E. R., supra note 367 , at 247 ("[I]t is merely an attempt to impress this fact on the jury that leads courts to incorporate the more emphatic statement in their charges.").

401. Manus v. Trans States Airlines, Inc., 835 N.E.2d 70, $72-73$ (Ill. App. Ct. 2005) ("The term 'highest degree of care' as used in the instruction given to the jury is not so technical or arcane as to require explanation. Any attempt to further define or explain the term would have quite possibly led to confusion and error." (quoting Lockett v. Bd. of Educ. for Sch. Dist. No. 189, 555 N.E.2d 1055, 1065 (Ill. App. Ct. 1990))); see also Votruba, supra note 331, at 704-05 (discussing jurors' understanding of the heightened care instruction).

402. See supra notes 345, 349-51, 357, 365-67 (charting various ways that juries may misunderstand and misapply the heightened standard).

403. Nunez v. Prof'l Transit Mgmt. of Tucson, Inc., 271 P.3d 1104, 1107 (Ariz. 2012) (“[A]n attempt to explain the common carrier doctrine to a jury would be riddled with the prospect of confusion.... To hold that a common carrier must exert more than reasonable care under the circumstances not only serves no useful purpose; it is a hard concept to make sense of and one very likely to be misunderstood." (quoting Lowery v. Montgomery Kone, Inc., 42 P.3d 621, 627 (Ariz. Ct. App. 2002))) .

404. See id. ("This Court found that this 'reasonably prudent man' instruction 'correctly states the law,' and that failure to give it 'tended to mislead the jury, by failing to point out sufficiently to it the limitations on the care required ... of a common carrier."') (quoting Atchison, T. \& S.F. Ry. Co. v. France, 94 P.2d 434, 437 (Ariz. 1939))).

405. Id. at 1109 ("[B]y requiring that a carrier exercise more care than that reasonable under the circumstances of the case, the 'highest degree of care' instruction approaches the insurance standard, as virtually every accident could be avoided if the carrier acted differently in some way.") (emphasis added). 
These emphatic jury instructions also distract jurors from examining how the patron's conduct contributed to the injury. ${ }^{406}$ Instead of focusing on the operator's conduct and the patron's behavior, jurors go on a mental marathon to sort out the meaning of unfamiliar legal standards and sort through the complex web of parties, claims, and defenses. ${ }^{407}$ Often, the only instruction that sticks with jurors is that the operator is liable for "even the slightest negligence." 408 Of course, that description suggests to the jurors that the operator cannot make any mistakes, while the patron's "slight" or "small" negligence appears fine because there is no similar language in the patron's duty description. ${ }^{409}$ With that understanding, jurors are reluctant to find against patrons and quick to dismiss the operator's contributory negligence, comparative fault, or assumption of risk defenses. Without those defenses, operators bear the full cost for patrons' self-inflicted injuries-a significant burden considering $65-85 \%$ of ride injuries stem from patrons violating posted rules. $^{410}$

Oddly, early courts' goal of incentivizing cautious passenger behavior by eliminating a carrier's liability for a passenger's carelessness was the central reason those courts both rejected strict liability for

406. See, e.g., Union Traction Co. of Ind. v. Berry, 121 N.E. 655, 658 (Ind. 1919) (arguing jury instruction with heightened standard prejudices the defendant); Houston \& Tex. Cent. Ry. Co. v. Keeling, 120 S.W. 847, 848 (Tex. 1909) (noting highest degree of care jury instruction by itself is inadequate because "attempting to define the carrier's duty only by the use of an adjective, are not apt to convey to the minds of jurors any very definite conception of the subject.").

407. Matt Milner, Highest Degree of Confusion: The Case Against the Common Carrier Doctrine, ARIZ. L. REV. SYL. (2011) ("Requiring a common carrier to exercise greater than reasonable care 'is a hard concept to make sense of and one very likely to be misunderstood.' As a result, when weighing the comparative fault between a common carrier and a passenger, the jury is charged with apportioning fault based on two different standards of care: the reasonable care standard governs the plaintiff's actions, but the highest degree of care standard applies to the defendants. The task of apportioning fault in a negligence case is always challenging, but when jurors are asked to apply different legal standards to different actors the challenge grows more complex." (citing Lowrey, 42 P.3d at 627)), available at http://www.arizonalawreview.org/?p=1493.

408. Hill v. Skywest Airlines, Inc., No. 1:06-cv-00801-SMS, 2007 WL 2326070, at *4 (E.D. Cal. Aug. 13, 2007) (citing Acosta v. S. Cal. Rapid Transit Dist., 465 P.2d 72, 77 (Cal. 1970)).

409. See Kaczorowski, supra note 42, at 1155 ("[C]ontributory negligence was a bar to passenger recovery. Nonetheless, if a carrier's negligence created a dangerous situation and alarmed passengers, courts were lenient in determining whether the passengers' behavior in the circumstances was reasonable.").

410. See Butler, supra note 178, at 402-03 ("Offering a 'fun day at the park,' however, should not excuse riders from understanding the risks involved. As an official of the IAAPA has said, 65$85 \%$ of accidents involving transportation-based amusement parks stems from riders breaking posted rules, either intentionally or inadvertently." (citing Gene Sloan \& Anthony DeBarros, Park Safety Rules Lax, USA TODAY, Apr. 7, 2000, at 1A)); Mulrine, supra note 189 ("Some rides pose specific risks, the report says: Spaceball, a popular ride, has caused five eye hemorrhages and a retinal tear since 1990. But rider stupidity causes many accidents. In at least one, a rider pushed a restart button just as others were disembarking."). 
passenger carriers and also attempted to create a liability standard that would require strong precautions while still limiting liability for responsible operators. ${ }^{411}$ As those courts noted, holding operators liable for a patron's injuries - especially injuries that were caused by the patron's own behavior - was unjust and unnecessary because a passenger could always protect himself from his own poor judgment. ${ }^{412}$

And the reasonable care standard embodies principles of selfaccountability by limiting a ride operator's liability when a patron is injured from ignoring an obvious danger or being careless. ${ }^{413}$ Further, applying reasonable care to both patrons and ride operators shines a spotlight on "the behavior of the parties" instead of emphatic phrases in the jury instructions. ${ }^{414}$ By focusing on the parties' conduct, jurors reach more consistent and fair decisions that award caution and punish carelessness. $^{415}$

Some proponents of the heightened standard argue that the prejudicial effect is overblown because jury instructions have little effect on the jury's ultimate finding. ${ }^{416}$ Proponents add that reasonable care is

411. See supra Part II.A.2.

412. See Budwick, supra note 60, at 355 ("However, because passengers are not inanimate and are able to care for themselves, courts considered it unjust to hold carriers strictly liable for injuries caused to passengers. Therefore, the common law required some degree of fault on the part of the carrier. The common law imposed a duty to use "the highest degree of care which a reasonable man would use.' . . . Such a high standard was justified because the carrier had committed to his trust the safety of people who were confined within the carrier's vehicle and who relied directly upon the carrier for safe transportation." (citing Kaczorowski, supra note 42, at 1157-59)).

413. Mosby v. Greyhound Lines, Inc., No. 06-13157, 2007 WL 4572049, at *6 (E.D. Mich. Dec. 27,2007 ) (repeating that reasonable care is a flexible concept that encourages passengers to avoid obvious dangers).

414. See Milner, supra note 407 ("When facing the possibility of being held to the highest degree of care - and as a consequence face a higher likelihood of liability - those parties will likely attempt to escape categorization as a common carrier. In a scheme that simply applies the reasonable care standard, this aspect of common carrier litigation would disappear. Instead the sole focus would be on whether the behavior of the parties was reasonable in light of the circumstances, not on whether they fall within the scope of the common carrier definition.").

415. See id. (citing Lowrey v. Montgomery Kone, Inc., 42 P.3d 621, 627 (Ariz. Ct. App. 2002)) (pointing out that jurors are likely to be confused over a heightened care instruction, especially for comparative fault determinations, because "jurors are asked to apply different legal standards to different actors"); Wood v. Groh, 7 P.3d 1163, 1169-70 (Kan. 2000) ("There is a substantial difference between the two standards proposed: ordinary care or the highest degree of care.... There is a real possibility that the jury would have returned a different verdict had the correct standard been given to the jury in measuring the conduct of the parents.").

416. See Votruba, supra note 331, at 704-05 ("In most cases the instructions are only passively heard once and do no more than tell the jury to evaluate what the ordinary reasonable person would do given the circumstances. The jury generally hears" no definitions for these terms, instructions on how to apply the standard, or how to match conduct to the standard. As a result, jurors "are largely left to their own devices to decide what is considered negligent"); Fleming Jr., supra note 331, at 680 (" $[\mathrm{I}] \mathrm{f}$ the jury is given the power to decide the case, it is impossible actually to prevent them 
no better because it is either undefined in jury instructions ${ }^{417}$ or defined with confusing legal jargon. ${ }^{418}$ True, courts do not give jurors an Excel spreadsheet, graphing calculator, or precise mathematical formula to compute the exact requirements of either standard of care. Nevertheless, "for over 150 years," 419 the reasonable care standard has governed the majority of negligence claims. ${ }^{420}$ Due to that long-standing tradition, courts, jurors, and litigants have a clearer understanding of the reasonable care standard than the heightened standard. ${ }^{421}$ That clarity creates consistent law from directed verdicts, summary judgment, and appellate reviews because judges and lawyers apply a common test (precaution commensurate with risk) for analyzing reasonable care. ${ }^{422}$

Also, while this test may sound like legal jargon, jurors are far more likely to understand a reasonable care test because, first, that has been the traditional standard in tort cases for over a century; and second, jurors can draw on their common understanding of "reasonability" to assess a case. $^{423}$ In contrast, jurors are unlikely to digest a jury instruction on the

from deciding it on any basis whatever which appeals to their own minds, tastes, prejudices, or emotions.... [T] he jury may decide the case on bases which they have been expressly told to disregard.”); Hetcher, supra note 331, at 641 (“[T] he line between the judge's sphere and the jury's does not separate an area of normative, law-like matters from one that is purely factual. It is a misconception to say that the jury simply applies the law. Its role is to decide the ultimate question of liability in the individual case before it.").

417. See Gilles, supra note 331, at 814-15 (emphasizing that jurors generally hear instructions but are not given a way to apply those standards in a cost-benefit manner); Wright, supra note 331, at 148 (noting that the Posner-esque and Learned Hand theories of negligence are not included in jury instructions, so the scholastic understanding of these tort concepts is "rarely actually employed in judicial opinions, and almost never explains the actual results reached by the courts") (citing Symposium on Negligence in the Courts: The Actual Practice, 77 CHI.-KENT L. REV. 423 (2002).

418. See Votruba, supra note 331, at 717-19 ("Although using pattern jury instructions that maintain technical accuracy is arguably very useful, it often results in instructions that are full of legal jargon and difficult to understand. This makes the jury's task more difficult and inhibits its ability to accurately apply the standard. ... [S]tudies show that jurors misunderstand the laws and instructions and this misunderstanding is often attributed to the confusing nature of legal language which is full of jargon or is overly vague."); Zipursky, supra note 60, at 2023 (arguing that "a factfinder who is asked what a reasonably prudent person would have done under certain circumstances has the right to think through that question however she wants," and the Posner conception of tort liability is thus only helpful if Judge Posner or a law student is a jury member).

419. Joe Schremmer, Comment, Avoidable "Fraccident": An Argument Against Strict Liability for Hydraulic Fracturing, 60 U. KAN. L. REV. 1215, 1232 (2012) (citing James A. Henderson Jr., Why Negligence Dominates Tort, 50 UCLA L. REV. 377, 386 (2002)).

420. See id. (citing Ind. Harbor Belt R.R. v. Am. Cyanamid Co., 916 F.2d 1174, 1177 (7th Cir. 1990)).

421. See supra notes 26-31, 364-65, 367-68 (supporting established tradition of reasonable care standard).

422. See discussion supra Part III.B.1.

423. See supra notes 364-65, 367 (speaking to jurors' ability to understand a reasonable care standard). 
heightened standard, as there is no common reference point for deciding if "there has been no negligence whatsoever, and [if] the damage or injury has been occasioned by inevitable casualty or by some cause which human care and foresight could not prevent."424 Further, even when instructions omit a specific test, the common meaning of "reasonable" suggests sensible precautions based on the particular circumstances. ${ }^{425}$ Conversely - applying the heightened standard to the same facts ${ }^{426}$-operators rarely prevail because jurors interpret the "highest degree of care" instruction as requiring endless and excessive precautions. $^{427}$

Moreover, jury instructions calling for "the highest degree of care" invade the jury's fact-finding function. ${ }^{428}$ The question of law is whether a duty of care exists. ${ }^{429}$ Then, the jury's function is to determine the necessary amount of care, given the circumstances, to meet that duty. ${ }^{430}$

424. Mark A. Franklin, Article, California's Extension of Common Carrier Liability to Roller Coasters and Similar Devices: An Examination of Gomez v. Superior Court of Los Angeles, 34 W. ST. U. L. REV. 29, 41 (2006) ("This has typically required carriers to prove "that there has been no negligence whatsoever, and that the damage or injury has been occasioned by inevitable casualty or by some cause which human care and foresight could not prevent." (quoting Kline v. Santa Barbara Consol. Ry. Co., 150 Cal. 741, 745 (1907))).

425. MERRIAM-WebSter DictionARY, Reasonable, Definition 1a-c, available at http://www.merriam-webster.com/dictionary/reasonable ("[B]eing in accordance with reason; not extreme or excessive; moderate, fair").

426. See Lopez v. Three Rivers Elec. Coop., Inc., 26 S.W.3d 151, 158 (Mo. 2000) ("If properly instructed, the jury would have been informed that the phrase 'ordinary care' means 'that degree of care than an ordinarily careful person would use under same or similar circumstances.' . . Put another way, under the facts of this case, the jury might have determined that Three Rivers was not liable because it did exercise ordinary care.").

427. See id. ("Prejudice is ordinarily presumed when a jury instruction imposes upon a party a standard of care greater than that required by law. The presumption is rarely rebutted.") (citation omitted).

428. See Frederick v. City of Detroit, Dep't of St. Rys., 121 N.W.2d 918, 922 (Mich. 1963) (arguing that the appropriate level of care is for the jury to decide based on the circumstances, so "[w]hen trial judges describe the standard of duty in terms of 'high care,' 'higher care,' 'highest care' or the like, they impinge upon the jury's function as finders of fact").

429. See id. at 923-24 ("[T]raditional concepts of trial by jury merits our emphasizing [that] ... [i]t is the court's function to determine as a matter of law whether the relation of the parties gives rise to a duty and to define it.... Accordingly, when a duty arises as a matter of law between a carrier and its passengers, it is the common law duty of due care and it may be defined simply as the duty to exercise such diligence as would be exercised in the circumstances by a reasonably prudent carrier. It then becomes the function of the jury to determine from the evidence what action, if any, should have been taken or omitted in order to measure up to the standard of a reasonably prudent carrier in the [sic] same circumstances. By instructing the jury that high care or the highest care is required of carriers, a court impinges upon the jury's obligation to determine the carrier's compliance with its duty of due care by consideration of the proofs of what a reasonably prudent carrier would have done in the circumstances disclosed by the evidence. It is for the jury to decide as a matter of fact, and not for the court to decide as a matter of law . ..."); Lopez, 26 S.W.3d 151, at 158 ("The appropriate standard of care is a question of law.").

430. Union Traction Co. of Ind. v. Berry, 121 N.E. 655, 658 (Ind. 1919). 
Granted, the jury's function is not unlimited. ${ }^{431}$ But directing the jury to require "the highest degree of care" conflicts with the traditional concept of trial by an impartial jury because the very description mischaracterizes the concept and sways jurors to find against ride operators and in favor of patrons. ${ }^{432}$ That bias can only be remedied with a flexible reasonable care standard because the jury can effectively sift through the infinite variations of water rides, patrons, and ride features that all play a role in water-ride injuries. ${ }^{433}$

\section{States with Common Carrier Statutes}

A word about the legislative role in this duty disagreement is helpful to address concerns about the potential for judicial overstepping. Several states have common carrier statutes that trickle into courts' analysis of the appropriate liability standard for water-ride operators. ${ }^{434}$ A detailed analysis of those statutes is beyond the scope of this Comment. Still, it is

431. See id.

432. Cereola \& Foucar-Szocki, supra note 28 , at 49 ("The special duty of care imposed upon a common carrier may be nothing more than [sic] the recognition of the special circumstances surrounding the operation of a carrier's facilities. Therefore, the greater the danger, the greater the responsibility required of the reasonable man of ordinary prudence which is the measuring stick of common law ordinary negligence standard. If so, then there should be no difference in the standard of care, in jurisdictions applying common carrier liability versus those that utilize an ordinary negligence standard. However, from a practical perspective, in a common carrier jurisdiction, a charge by the Court to the jury, directing a heightened standard of care, may very well sway the jury in favor of the plaintiff whenever the evidence is susceptible to a favorable interpretation for either side.").

433. Mosby v. Greyhound Lines, Inc., No. 06-13157, 2007 WL 4572049, at*6 (E.D. Mich. Dec. 27,2007 ) (pointing out that it is the jurors' role to "determine what is reasonable given the nature of the risks involved and the standards and customs of the defendant's business").

434. The vast majority of states have some sort of common carrier statute. See KAN. STAT. ANN. $\S \S 66-1,111,66-1,142$ b (West 2014) (requiring private and public carriers to comply with common carrier regulations or be subject to civil penalties); TEX. TRANSP. CODE ANN. § 5.001(a)(1) (West 2013) (applying common law duties and liabilities to common carriers in Texas); GA. CODE ANN. § 46-9-132 (West 2014) (requiring "[a] carrier of passengers [to] exercise extraordinary diligence to protect the lives and persons of his passengers"); MO. ANN. STAT. $§ 537.250$ (West 2014) (expanding liability for common carriers to include "any loss, damage or injury to ... property"); VA. CODE ANN. § 56-119 (West 2014) (prohibiting attempts to exempt carrier from liability for "any loss, damage, or injury to freight or passengers in its custody and care as a common carrier”); IOWA CODE ANN. § 327D.7 (West 2015) (prohibiting exculpation agreements to eliminate carrier liability); NEV. REV. STAT. ANN. $\S \S 706.036,706.291$ (West 2014) (requiring liability insurance for broadly defined group of common carriers); 66 PA. CONS. STAT. ANN. $§ 2304$ (West 2014) (establishing liability generally for common carriers). California, Oklahoma, and North Dakota all have nearly identical common carrier statutes that require carriers for reward "use the utmost care and diligence for their safe carriage, must provide everything necessary for that purpose, and must exercise to that end a reasonable degree of skill." CAL. CIV. CODE $\$ 2100$ (West 2014); see also N.D. CENT. CODE ANN. § 8-02-02 (West 2013) (replacing "must" with "shall”); OKLA. STAT. ANN. tit. 13, $\S 32$ (West 2013) (using identical language to the California statute). 
important to understand why courts are not running afoul of legislative intent by adopting a reasonable care standard.

Some proponents of the heightened care standard argue that amusement rides must be treated as common carriers because various state statutes addressing carriers indicate a legislative intent to apply the heightened standard to ride operators. ${ }^{435}$ Accordingly, those proponents question whether courts have authority to apply a reasonable care standard absent either legislative permission or revisions to the particular state's carrier statute. ${ }^{436}$

Though several states have common carrier statutes, only Oregon's statute explicitly applies the heightened standard of care to amusementride operators. ${ }^{437}$ Other courts rely on analogies between thrill rides and common carriers to link the heightened standard with a legislative purpose; ${ }^{438}$ and several courts disagree about the accuracy of those analogies. $^{439}$

435. See Cal. Civ. Code $\S 2100$ (West 2014); N.D. Cent. Code AnN. § 8-02-02 (West 2013); OKLA. STAT. ANN. tit. 13, § 32 (West 2013).

436. See Gomez v. Superior Court, 113 P.3d 41, 53 (Cal. 2005) (Chin, J., dissenting) (noting that courts are required "to determine the Legislature's intent when it enacted the statute"); Butler, supra note 178, at 379 (linking courts' attempts to mix common-law concepts and legislative intent with the increasing division over ride liability standards).

437. See OR. Rev. Stat. AnN. § 460.355(2) (West 2014) ("The [amusement ride] owner or operator shall be deemed not a common carrier; however, such owner or operator shall exercise the highest degree of care for the safety of users.").

438. Interestingly, Missouri's common carrier statute only applies to transportation "by motor vehicle ... upon the public highways and airlines engaged in intrastate commerce." Mo. ANN. STAT. § 390.020(6) (West 2014). That statute also defines a motor vehicle as "any vehicle, truck, truck-tractor, trailer, or semitrailer, motor bus or any self-propelled vehicle." Id. § 390.020(19). However, the Missouri Appellate Court's Chavez decision applied common carrier liability to operation of a water slide that was neither located on a public highway nor employed a motor to propel the rafts. See Chavez v. Cedar Fair, LP, No. WD75373, 2013 Mo. App. LEXIS 843 at *1-3 (Mo. Ct. App. July 16, 2013) (explaining that passengers on a raft simply slide down the flume). Thus, according to the text of Missouri's statute, water slides do not fit the definition of a common carrier. The Chavez appellate court explained that applying the heightened standard of care did not mean the slide operator was classified as a common carrier. Id. at*14-16 n.6. Rather, the slide operator was simply required to exercise the same standard of care as a common carrier because slide patrons lacked freedom of movement and could neither cause nor prevent an accident. Id. However, that distinction may not resolve a conflict with legislative intent. If the legislature passed a statute requiring insurance companies with 100 employees to pay higher taxes, it would seem strange for the court to find that a meat distribution company also had to pay higher taxes because the meat company had 100 employees. It is unclear whether the court could side-step the design of the statute - higher taxes for large insurance companies - by applying the effect of the statute to a company without also classifying that company as an insurance company. Indeed, statutory authorization may be required for the court to separate classification from duty imposition. See OR. REV. Stat. ANN. § 460.355(2) (West 2014) (explaining, in text of statute, that an amusement ride "operator shall be deemed not a common carrier; however, such owner or operator shall exercise the highest degree of care for the safety of users."). As a result, Missouri courts appear to be applying common-law concepts regarding common carriers instead of turning to specific legislative materials 
If the legislature intended for operators of dangerous thrill rides to exercise heightened caution, then combining the reasonable care standard with a rebuttable presumption accomplishes the legislature's goal because elevated risks will still demand elevated and commensurate precautions. ${ }^{40}$ On the other hand, the heightened standard is a blanket liability standard that conflicts with legislative intent by increasing liability both for rides that resemble common carriers and also rides that lack any resemblance. ${ }^{441}$ But even with Oregon's carrier statute, or a similar statute, the legislature should provide a specific legal test that clarifies where reasonable care ends, where heightened care begins, and how to measure the upper limits of the heightened standard. ${ }^{442}$ Absent this type of clarification, courts cannot consistently apply the "highest

to interpret state carrier laws. To be sure, the Missouri Supreme Court did address this issue in its decision to reverse the appellate court's Chavez decision. See Chavez v. Cedar Fair, LP, No. SC93658, 2014 Mo. LEXIS 220, at*21-22 (Mo. Nov. 12, 2014) (holding that the "established definition of 'common carrier' does not, as an overall rule, encompass an amusement park that operates attractions for the purpose of providing amusement to patrons"). But the supreme court's discussion of common carrier statutes focused on patrons' purpose to be entertained by the ride instead of being transported to a particular location. See id. at *22 (emphasizing that a company "cannot fall under the common carrier definition" if the company's purpose is to provide entertainment and fun to riders because the company is considered to be in the entertainment business instead of the transportation business). While the patrons' purpose was at the heart of decision to overrule the appellate court, the supreme court never cited or discussed any statutory text or legislative history when analyzing Missouri's common carrier laws. Id. at *20-22. So, it remains unclear if the common law doctrines surrounding common carriers - and the court's application of these legal concepts to select business activities - compliments or offends the Missouri legislature's intent. And without an in-depth analysis of the relevant statutes and legislative materials, one may be confused about why the Missouri Supreme Court said that patrons' purpose in getting on thrill rides disqualifies common-carrier liability, yet - just two paragraphs later in the same opinion - the court held that the common-carrier standard of exercising "the highest degree of care" applied to every person who operates a motor vehicle in Missouri. See id. at *23 (requiring "automobile operators to exercise the highest degree of care"). Under the supreme court's holding, a driver's purpose in operating a vehicle - be it driving children to school in a van or drag racing on a motorcycle without a passenger - has no effect on the applicable liability standard. Yet, the purpose of getting on an amusement ride is the driving, dispositive factor for applying a different liability standard. $I d$. The bottom line is that courts often turn to common-law concepts instead of legislative materials when analyzing common carrier issues - an approach that upholds legal tradition while ignoring legislative intent. For an example of a court examining both case law definitions and also statutory definitions of common carriers to determine whether to apply a heightened standard of care, see Summers v. Montgomery Elevator Co., 757 P.2d 1255, 1261-62 (Kan. 1988) (refusing to apply common carrier liability to elevator operator because elevator was outside the scope of statutory and case law definitions of common carrier).

439. See supra note 436 and accompanying text.

440. The reasonable care standard accomplishes the legislature's goal because elevated risks demand elevated care commensurate with the risk. See supra notes 26-31, 364-65, 367-68 (analyzing reasonable care formula).

441. See supra notes $345,349-51,357,365-67$ (highlighting lack of flexibility when applying heightened standard).

442. See Gomez v. Superior Court, 113 P.3d 41, 53 (Cal. 2005) (Chin, J., dissenting) (disputing courts' role when these type of statutes exist). 
degree of care" standard in a way that fulfills the legislature's intent because courts, litigants, and jurors all disagree about the standard's meaning and effect. ${ }^{443}$

\section{Practical Pooling: Swirling a Standard of Reasonable Care with a Rebuttable Presumption. ${ }^{444}$}

Combining a rebuttable presumption with the reasonable care standard creates a clear, consistent approach that resolves traditional common carrier concerns about operator control and patron vulnerability. ${ }^{445}$ Specifically, the reasonable care standard protects vulnerable patrons because operators must take precaution commensurate with the risk of patron injury. ${ }^{446}$ In addition, the rebuttable presumption evens the control disparity between operators and patrons by requiring operators to explain the cause of water-ride accidents. ${ }^{447}$ Furthermore, the dynamic duo of reasonable care and the rebuttable presumption flushes away the problems of infinite liability and jury confusion that flow from the heightened standard.

\section{Resolving Evidentiary Issues that Exist Independent of a Liability Standard}

In water-ride cases, the applicable liability standard is the chief concern for ride operators. But the premier issue for patrons is not the

443. See supra notes $345,349-51,357,365-67$ (illustrating confusion over meaning of the heightened standard).

444. This section discusses a rebuttable presumption of negligence. This concept is distinct from the close-cousin concept, known as res ipsa loquitor. However, courts frequently interchange the labels for these two concepts, so it is difficult to separate the doctrines based on title alone. Thus, this Section cites several cases discussing "res ipsa loquitor," but, in application, those cases focus more on the rebuttable presumption. For a more detailed discussion of res ipsa loquitor, see Stuart M. Speiser, The Negligence Case: Res IpSa Loquitur § 1:9 (1972); and E. I. Du Pont De Nemours \& Co. v. Cudd, 176 F.2d 855, 857-58 (10th Cir. 1949).

445. See Webb, supra note 42, at 127-28 (noting that the rebuttable presumption should be on the better-informed party because, historically, '[t]his potential 'information gap' has become a prominent rationale for allowing evidentiary presumptions under res ipsa loquitur. Mansfield sagely recognized the plaintiff's disadvantage in unexpected accident cases, asking rhetorically, 'What other evidence can the plaintiff give?' He pointed out how the sailor had had no ability to judge either the soundness of a coach or the skills of its driver and consequently had been dependent on the expertise of the defendant and his employees.").

446. See Gerardi, supra note 276 , at 184-85 (noting that reasonable care already requires increased precaution for more dangerous rides).

447. See O'Callaghan v. Dellwood Park Co., 89 N.E. 1005, 1007 (Ill. 1909) (noting that "[i]f the injury of a passenger is caused by apparatus wholly under the control of a carrier and furnished and managed by it, and the accident is of such a character that it would not ordinarily occur if due care is used, the law raises a presumption of negligence."). 
liability standard but "the availability and adequacy of [causation] evidence." ${ }^{448}$ After all, a jury never decides if an operator was negligent if patrons lack sufficient causation evidence to survive a motion to dismiss and summary judgment. ${ }^{449}$ Thus, while reasonable care is the appropriate liability standard, this standard must be combined with a rebuttable presumption in order to create an even playing field for operators and patrons alike.

The rebuttable presumption is an evidentiary concept that helps injured plaintiffs who lack access to causation evidence. ${ }^{450}$ In nearly all water-ride cases, there exists a wide gap between a ride operator and an injured patron who knows little to nothing about ride mechanics and lacks access to evidence about an accident's cause. While a patron may remember crashing into a ride wall, the patron often cannot pinpoint the source or cause of the crash. And where patrons are on a ride where the operator controls the patrons' movement, patrons are even less likely to know what caused an accident. ${ }^{451}$

On the other end of the gap is a ride operator who is usually familiar with a ride's mechanics, problem areas, accident history, and-above all - has the best access to evidence about the cause of the accident. Where an operator controls patrons' movements on a ride, the operator is often the only eyewitness with key details about the cause of an accident.

To fill this causation and evidentiary gap, the rebuttable presumption "shifts to the [operator] the obligation to explain" the cause of the patron's injury. ${ }^{452}$ But this presumption does not overburden the

448. Myrlak v. Port Auth., 723 A.2d 45, 51 (N.J. 1999).

449. See id. (noting the need for a threshold evidentiary rule).

450. See S. Pac. Co. v. Hogan, 13 Ariz. 34 (Ariz. 1910) (finding negligence presumed when train derailed).

451. See Myrlak, 723 A.2d at 51 (discussing the primary evidentiary purpose of res ipsa loquitor); Aiken, supra note 87, at 25 ("The basic concept of res ipsa loquitur is that the result (i.e., injury or damage) would not occur if one with exclusive management and control of an instrumentality uses it properly. It is not a principle of substantive law but of evidence" (citing Zukowsky v. Brown, 488 P.2d 269, 276-78 (Wash. 1971)); Kimberly Haag, Note, Res Ipsa Loquitur: A Step Along the Road to Liability Without Fault Do Physicians Have A Fighting Chance in the Face of the Modern Application of This Doctrine in Medical Malpractice Cases? A Closer Look at the New Fiction, 42 BRANDEIS L.J. 149, 153 (2003) (noting that "all jurisdictions agree that the mere happening of an accident does not justify recourse to the doctrine of res ipsa loquitur." (citing RESTATEMENT (SECOND) OF TORTS $\S 328 \mathrm{D}$, cmt. c (1965))). For the two traditional requirements that a plaintiff must satisfy to apply res ipsa loquitor, see Turk v. H. C. Prange Co., 119 N.W.2d 365, 369 (Wis. 1963).

452. Myrlak, 723 A.2d at 51; St. Louis Sw. Ry. Co. v. Parks, 76 S.W. 740, 742 (Tex. 1903) (pointing out the obvious example that "an injury to a passenger on a railroad resulting from a derailment of a train or the abnormal operation of the machinery gives rise to an inference of negligence"); see also Matthew R. Johnson, Note, Rolling the "Barrel" A Little Further: Allowing Res Ipsa Loquitur to Assist in Proving Strict Liability in Tort Manufacturing Defects, 38 WM. \& 
operator because "what is required of [the operator] is an explanation, not exculpation." 453 Thus, the operator does not have to disprove negligence to rebut the presumption. ${ }^{454}$ Instead, the operator merely needs to provide evidence of ride precautions and other causative factors so that a jury could determine if those precautions were reasonable or whether the accident was unforeseeable. ${ }^{455}$ After the operator provides sufficient causation evidence, the burden of proving negligence reverts to the patron. ${ }^{456}$

The ride operator is also in the best position to provide evidence about the causative circumstances of the accident. ${ }^{457}$ For instance, if a $\log$ flume boat derails ${ }^{458}$ while plummeting "in total darkness" 459 at 36 miles per hour ${ }^{460}$ down an 85 -foot-tall channel ${ }^{461}$ with roaring water

MARY L. REV. 1197, 1204 (1997) (Hereinafter "Matthew") (explaining that applying res ipsa loquitor "creates a rebuttable presumption of negligence, and the jury must presume the conduct sued upon to be negligent unless the defendant puts on evidence to counter the presumption." (citing Newing v. Cheatham, 540 P.2d 33, 42-43 (Cal. 1975))).

453. Myrlak, 723 A.2d at 51 (quoting Buckelew v. Grossbard, 435 A.2d 1150, 1157 (N.J. 1981)).

454. Kohl v. Disneyland, Inc., 201 Cal. App. 2d 780, 782-84 (Cal. Ct. App. 1962) (noting that plaintiff still has the burden to show that the accident occurred, but then, the burden shifts to the defendant to explain that the cause-in-fact and proximate cause were not the defendant's negligence).

455. Myrlak, 723 A.2d at 51 (citing Buckelew, 435 A.2d at 1150); Johns Hopkins Hosp. v. Correia, 174 Md. App. 359, 374 (Md. Ct. Spec. App. 2007) (pointing out that passengers lacks technological expertise of machinery and appliance, as well as defects, and that lack makes the passenger dependent on the carrier's proper care).

456. Diaz v. L.A. Cnty. Metro. Transp. Auth., 2009 Cal. App. LEXIS 1217, at*1-4 (Cal. App. 2d Dist. July 23, 2009) (explaining that after the defendant produces evidence that supports reasonable care, then the burden shifts back to the plaintiff to prove negligence with contrary evidence).

457. See Young, supra note 92, at 265-66 (pointing to courts' division on the following issue: "The carrier is expected to explain how the collision occurred because his employees have been in a better position than the plaintiff to have seen what happened .... Whether a plaintiff in such a case should be in a position to make out a prima facie case by showing merely the happening of the collision, and the relationship between himself and the defendant, is a matter of policy upon which the courts are not in accord.").

458. See supra note 3 and accompanying text.

459. See Log Flume, TOWERSTIMES, http://old.towerstimes.co.uk/history/oldrides/logflume.htm (last visited Feb. 3, 2015) ("Once the longest Log Flume in the world, this ride was basically an aquatic rollercoaster and was based on Canadian water chutes that are used to transport logs from forest to riverside. There was nearly 1 kilometre of waterway winding through woodlands with three drops during the ride: the first was a large lift hill, but a small drop, to gain some height. The second drop was in total darkness and the final drop was the real drencher.").

460. Viking Revenge Flume, SEA WORLD, http://seaworld.com.au/animals-rides-andshows/rides/viking-revenge-flume.aspx (last visited May 8, 2015) (giving the following statistics: "Height13m | 41ft, Speed58km/hr | 36MPH, Length460m | 1,509f").

461. Timber Mountain Log Ride, KNOTTS BERRY FARM, https:/www.knotts.com/rides/WaterRides-1-5-12-21/Timber-Mountain-Log-Ride (last visited May 8, 2015) ("This classic attraction, which opened at Knott's Berry Farm in 1969, remains as one of the most elaborate log flume rides in 
pumps constantly cascading 24,000 gallons of water throughout the ride $^{462}$ - it is highly unlikely that a patron's conduct is to blame for the derailment of the ride's 771 pound boat. ${ }^{463}$ And other than the rare case where a patron designs water rides for a living, most patrons injured on a log flume lack information about the accident's cause and have only the accident itself as evidence of negligence. ${ }^{464}$

Even if the patron remembers a few key details, it is unlikely that the patron can put enough pieces of evidence together to accurately determine if the accident's cause was a defect in the boat track, the water pumps, an electrical failure, a computer error, the operator's pressing of a wrong button, the park's failure to identify a broken ride component or even inspect the ride at all, or some unforeseeable and unpreventable "act of God." $" 465$ This knowledge gap demonstrates that it is not enough for a patron to have evidence that an accident occurred-the patron also needs, but often cannot obtain, proof that the accident was caused by a

the U.S. The much anticipated attraction opened in July 11, 1969 with screen legend John Wayne taking the inaugural ride").

462. Timber Mountain Log Ride Will Undergo Major Renovation, KnOtTS BERRY FARM, https://www.knotts.com/boardwalk/media-center/log-ride-press-kit (last visited May 8, 2015) ("The Calico Log Ride, as it was originally named, takes guests through an 85 -foot-high by 330 -foot-long mountain range themed to a nineteenth-century lumber camp. The ride, housed in an eight-story building, includes 24,000 gallons of water that circulates free floating logs past a variety of mechanical figures and taxidermied animals culminating in a 38 foot fall.").

463. Physics Day at Busch Gardens, LOG FLUME: ADVANCED 80 (May 19, 2013),

http://sphsdevilphysics.weebly.com/uploads/5/0/7/1/5071691/ib_physics_day_guide.pdf (showing that the mass of the $\log$ in one log flume was 350 kilograms); But see Pete Cavender, So Fat He Sank the Log Flume, FORZA BLOG (Oct. 3, 2013), http://www.forzasupplements.co.uk/blog/news/sofat-he-sank-the-log-flume/\#.UvLx0mSwJDE ("The boat went up a ramp, before speeding downhill with a big splash. We were absolutely soaked! But as we neared the end of the ride, the boat came to a sudden halt. 'What's happening?' I mused. Seconds later, another boat smashed into the back of us. 'I think we are stuck,' I mumbled. After a minute, there were even more boats piling up behind us. I knew exactly why. . .Waiting at the end of the ride, I could see the girls were giggling, but I was mortified. I was weighing down our boat so much it couldn't move through the shallow water! Unsure what to do, I grabbed the wall and the side of the ride and used my hands to push our boat away from the pile-up. 'Talk about a splash landing[]'").

464. See Johnson, supra note 93, at 262 (surveying early negligence cases and noting that "wrongly injured plaintiffs had no way to recover if the evidence establishing the injury was solely in the hands of the defendant." (citing Ronald J. Allen, Burdens of Proof, Uncertainty, and Ambiguity in Modern Legal Discourse, 17 HARV. J.L. \& PUB. POL'Y 627, 632 (1994))).

465. Id. at 262 (citing RESTATEMENT (SECOND) OF TORTS, § 328D cmt. c (1965)) (noting the increased importance for res ipsa loquitor with injuries from modern machinery because of increased complexity and ease of misuse by operators); Bibeau v. Fred W. Pearce Corp., 217 N.W. 374, 376 (Minn. 1928) (arguing, in a roller coaster case, that "new and credulous patrons seeking thrills on a roller coaster of the character of this one are subjected to much greater danger than is generally realized.”); O'Callaghan v. Dellwood Park Co., 89 N.E. 1005, 1006-07 (Ill. 1909) (pointing to danger of thrill ride to justify heightened care). 
specific act or omission of an identifiable, culpable, and negligent operator. ${ }^{466}$

In comparison, the ride operator likely has access to an ocean of evidence about the circumstances that contributed to this hypothetical log flume accident. This access stems from the operator's control over the ride instrumentalities and specialized knowledge about the particular ride, which places the operator in the best position to obtain evidence and explain the likely cause of the patron's injury. ${ }^{467}$ And, perhaps the most important information, the ride operator can place the pieces of evidence in chronological order because, unlike the patrons who are caught up in the ride's thrills and sensations, the operator often is relaxed and has a big-picture view of the events leading up to the accident. ${ }^{468}$ In fact, operators are frequently eyewitnesses to the accident and are thus in the best position to explain the cause. ${ }^{469}$

In addition to being at the scene of the accident, ride operators have easy access to employees and contractors who may have inspected, repaired, maintained, or tested the ride. Any one of those individuals may know about unique problems or concerns with a ride componentrisks that are unknown to patrons. ${ }^{470}$ Likewise, operators have specialized knowledge about the ride's technological features. ${ }^{471}$

466. See Benedick v. Potts, 40 A. 1067, 1068-69 (Md. 1898) (holding res ipsa loquitor did not apply where the railway car passenger was found unconscious, on the side of the tracks, and unable to recall the cause of his injury after the train went through a tunnel); see also Fisk v. Chi. Water Chute Co., 119 Ill. App. 536, 541 (1905) (declaring that plaintiff alleging negligent operation of a boat ride had the burden to provide specific evidence of negligence and could not apply res ipsa loquitor); Akhter v. Schlitterbahn Beach Resort Mgmt., L.L.C., No. 03-13-00117-CV, 2013 WL 4516130, at*6 (Tex. App. Aug. 22, 2013) (finding that an injured water-ride patron had "no more than a scintilla of evidence - if any evidence - that this event was attributable to any acts or omissions by water park personnel.... Mere proof that [a patron] was injured at a [] water park is not proof of proximate cause."); Johnson, supra note 93, at 262 (explaining that plaintiffs cannot recover if all the causation evidence is in the hands of the defendant).

467. Rivere v. Thunderbird, Inc., 353 So. 2d 346, 348 (La. Ct. App. 1977) (involving an injury where "the defendant had control over three factors which the trial judge touched upon in his oral reasons, to-wit: (1) the slide itself, (2) the water, and (3) the notice to patrons.").

468. See Young, supra note 92, at 265-66 (explaining the knowledge gap between patrons and operators).

469. See id. (noting that res ipsa loquitor helps injured patrons "where it would be difficult for him to know definitely what the carrier's employees had failed to do or to discover what they had done improperly.... The carrier is expected to explain how the collision occur[]ed because his employees have been in a better position than the plaintiff to have seen what happened.").

470. See Bibeau, 217 N.W. at 376 (finding that patrons do not understand the scope of ride dangers).

471. Johns Hopkins Hosp. v. Correia, 921 A.2d 837, 846 (Md. Ct. Spec. App. 2007) (noting patrons' dependence on the ride operator). 
Consequently, operators can quickly determine whether the use or misuse of a ride component or complex mechanical device is to blame. ${ }^{472}$

What is more, the operator may be the only individual to inspect the ride because nearly one-third of thrill rides "are never inspected by any public official." ${ }^{473}$ In short, ride operators should have little trouble with producing sufficient evidence to rebut the presumption.

\section{The Synergistic Relationship Between Reasonable Care and a Rebuttable Presumption}

Despite the operator's well of information, there will still be cases where the cause of the accident is unclear. That being so, a deep dive through courts' water-ride jurisprudence revealed no cases where an operator was both presumed negligent and also failed to identify some other cause of an accident. Given that the rebuttable presumption does not require operators to definitively prove the cause of the accident, there is little need for operators to worry about being unable to rebut the presumed negligence. ${ }^{474}$ The presumption is less about proving reasonable care, and much more about digging through several potential causes for the patron's injury-including evidence of the patron's conduct on the ride or a ride component that may or may not be defective. ${ }^{475}$ And if the ride operator does struggle to identify potential causes of an accident, then patrons would certainly be in a far worse position in trying to locate clues and assemble a causation theory. In those difficult cases, it may take patrons so long to piece together the accident that the statute of limitations expires. ${ }^{476}$

Additionally, where an operator points to, for example, a design defect as the cause, the presumption extends to the designer as well. ${ }^{477}$

472. See Johnson, supra note 93, at 283 (1996) (citing RESTATEMENT (SECOND) OF TORTS, $\S$ $328 \mathrm{D} \mathrm{cmt.} \mathrm{c} \mathrm{(1965))} \mathrm{(providing} \mathrm{that} \mathrm{specialized} \mathrm{dangers} \mathrm{require} \mathrm{specialized} \mathrm{knowledge).}$

473. Mulrine, supra note 189, at 59.

474. See Norman v. Thomas Emery's Sons, Inc., 218 N.E.2d 480, 482 (Ohio Ct. App. 1966) (connecting a presumption of negligence with a contributory negligence defense).

475. Hipps v. Busch Entm't Corp., No. Civ. A. 97-1907, 1997 WL 535181, at*4-5 (E.D. Pa. July 31, 1997) (explaining that res ipsa loquitor is not a substantive law, but a rule of evidence. "Accordingly, the plaintiff need not prove that the defendant had exclusive management or control of the injury producing instrument. ... '[T]he critical inquiry is not control but whether a particular defendant is the responsible cause of the injury."' (quoting Gilbert v. Korvette, 327 A.2d 94, 101 (Pa. 1974))).

476. Id.

477. Fowee v. Paramount Parks, Inc., No. CA98-09-116, 1999 WL 138694, at*2 (Ohio Ct. App. Mar. 15, 1999) (involving a plaintiff whose only evidence of a design defect was his injury, but the plaintiff lacked any evidence showing fault). 
So, a patron is not punished by the ride operator's inability to determine what caused the ride to malfunction. ${ }^{478}$ As a result, notwithstanding today's extensive discovery methods, the rebuttable presumption still achieves the goal "at the heart of modern litigation theory" by incentivizing parties with superior knowledge to fully produce accurate information. ${ }^{479}$

When a case centers on the patron's conduct, the operator can still rebut the presumption of negligence with evidence of the operator's reasonable precautions, such as safety reports, inspection logs, or warning signs. Then, courts can balance the operator's precautions with inherent water-ride risks. For instance, in Valentin v. Six Flags, a slide operator argued that the patron should have recognized the park's slippery surfaces, which were an inherent part of the water park. ${ }^{480}$ Then, as evidence of reasonable care, the operator provided the ride's inspection instructions. ${ }^{481}$ But the operator had not actually performed any inspections, which is why the operator failed to discover that the slide's steps were slick and unstable due to an extensive mildew accumulation that was growing underneath the slide's platform. ${ }^{482}$ In that case, it was unreasonable for the operator to abstain from inspecting the ride for so long that a hidden heap of mildew covered the slide steps and created a hazard for patrons. ${ }^{483}$

However, in Desai v. Silver Dollar City, the operator rebutted the presumption of negligence by producing posted signs and loudspeaker warnings - that the patron admitted to reading and hearing - instructing patrons to stay inside the raft during the ride. ${ }^{484}$ The burden shifted to

478. Id.

479. See Johnson, supra note 93, at n.10 ("The rule persists in these post-discovery days because of its added incentive to the full production of information, which is at the heart of modern litigation theory." (quoting Ronald J. Allen, Burdens of Proof, Uncertainty, and Ambiguity in Modern Legal Discourse, 17 HARV. J.L. \& PUB. POL'Y 627, 628 (1994))).

480. Valentin v. Six Flags Over Ga., L.P., 649 S.E.2d 809, 812-13 (Ga. Ct. App. 2007) (internal citations omitted) (rejecting the park owners argument because there was only evidence that cleaning procedures existed, but not that they were followed. As the court explained, "evidence that the hazard was a mildew substance allows for an inference that the hazard was permitted to exist in the area for an unreasonable period without being remedied, and therefore, creates a genuine issue of material fact over whether the alleged inspection was adequate... Under these circumstances, whether the hazard was discoverable upon a reasonable inspection is an issue necessitating jury resolution.").

481. Id.

482. Id.

483. See id. at 811-13 (noting that the mildew had accumulated to such an extent that it was reasonable to infer either notice of the problem or a lack of reasonable care in maintaining the steps).

484. Desai v. Silver Dollar City, Inc., 493 S.E.2d 540, 545 (Ga. Ct. App. 1997) (noting that there was no negligence when a woman, who had ridden a raft ride before and was again instructed 
the patron, a physics major, who was injured after disobeying the warnings, jumping out of the raft, and being hit by an oncoming raft. ${ }^{485}$ While the patron alleged that the operator was negligent by sending the raft down too quickly, ${ }^{486}$ the court found for the operator. The court explained that the patron assumed the risk of being hit by the raft by choosing to disregard the operator's warnings and jump out of her own raft. ${ }^{487}$

Both Valentin and Desai illustrate that the rebuttable presumption resolves the evidentiary concerns for patrons, and the reasonable care standard resolves the infinite liability concern for ride operators by balancing unique ride risks with appropriate caution. ${ }^{488}$ This flexible, balanced, and information-generating approach is essential to cope with the infinite variety of fact-sensitive water-ride cases. And with modern parks selling "tickets to a wide range of people[,] including those who may be unable to foresee, understand or comply with what is expected of them," ${ }^{489}$ this flexible reasonability-presumption combo will only increase in effectiveness.

\section{A Default Rule}

Finally, courts should apply the rebuttable presumption as a default rule in water-ride cases. While courts have different requirements for

not to leave the raft, jumped and was hit by another raft. As the court explained, "she voluntarily assumed came to pass. In effect, even though she was warned do not do this or you might get hurt, Mrs. Desai tested the danger until she was hurt. It defies both logic and our law to permit a recovery under this evidence. Further, although the dissent discusses many possible acts of negligence whether active or passive, e.g., failure to communicate between the top and bottom of the slide, lifeguards not immediately present, etc., the obvious fact remains that none of these acts would have resulted in Mrs. Desai's injury if she had remained in the raft as she was instructed.").

485. See id. at 543, 546 .

486. See id. at 546 (Eldridge, J., dissenting).

487. Id. at 545 .

488. Marley v. Silver Dollar City, Inc., 400 S.E.2d 337, 337 (Ga. Ct. App. 1990) (applying the assumption of risk defense to a patron who fell off a slide because, under Georgia law, "A person who rides or uses an amusement device assumes the hazards naturally and obviously arising from the proper use and operation of the device, such as the hazards inherent in the operation of a miniature car or scooter, if it is properly designed, constructed, and maintained'... We conclude that the risk of landing upside down after being propelled downward by the force of gravity and flow of water was a normal hazard of the 'Bonzai Pipeline"'(quoting Atlanta Funtown v. Crouch, 152 S.E.2d 583, 590 (Ga. Ct. App. 1966))). Compare Kahalili v. Rosecliff Realty, Inc., 141 A.2d 301, 306-07 (N.J. 1958) (applying res ipsa lquitor and reasonable care standard where plaintiff fell out of a roller coaster), with Gomez v. Superior Court, 113 P.3d 41, 47-48 (Cal. 2005) (applying heightened standard of care to an amusement park based personal injury suit).

489. Avery \& Dickson, supra note 10, at 305 (noting that "ride owner/operators agree to sell tickets to a wide range of people including those who may be unable to foresee, understand or comply with what is expected of them."). 
applying the presumption, ${ }^{490}$ the requirements still center around the requirement for patrons to show that the "injury does not normally occur without negligence caused by an instrumentality under the defendant's exclusive control." ${ }^{491}$ The inconsistent application of the heightened standard is proof that each ride offers patrons and operators a different degree of "control." Trying to categorize rides into 'enough-control' and 'not-enough-control' buckets for applying the presumption is a futile endeavor. That said, the rebuttable presumption might be inappropriate for swimming pools because patrons neither "ride" a swimming pool, nor do operators control patrons' movements. Nevertheless, that line may be arbitrary because several waterpark pools employ flotation devices or boats, wave-generating equipment, and other mechanical devices like spray cannons and water jets; all features that can affect patrons' control or present risks about which operators have superior knowledge. Hence, courts should rarely, if ever, refrain from applying the rebuttable presumption to water-ride cases. By so doing, courts diminish concerns about clarity and create a clear, uniform treatment for water-ride cases. ${ }^{492}$

\section{CONCLUSION}

Combining a reasonable care standard with a rebuttable presumption provides a win-win solution for courts, patrons, and ride operators. The reasonable care standard creates consistency and protects operators from infinite liability. The rebuttable presumption produces otherwiseobscured causation evidence and thereby protects injured patrons. Water rides are too diverse for the current web of common carrier liability

490. See Alan H. Konig, Tort Law-Res Ipsa Loquitur in Medical Malpractice Actions: Mireles v. Broderick, 23 N.M. L. REV. 411, 412-13 (1993) ("The doctrine [of res ipsa loquitur] has now been accepted and applied in all jurisdictions." (citing W. PAge KeEton Et Al., Prosser And KeEton ON THE LAW OF TORTS $\S 39$ (5th ed. 1984))); Johnson, supra note 452, at 1202 (noting that "almost every state has embraced [] res ipsa loquitor." This may be difficult to trace because several courts mix up the rebuttable presumption with res ipsa. But the concepts share a similar basic premise with which courts are likely to be familiar (citing 1 Stuart M. Speiser, The NegligenCE CASE: ReS IPSA LOQUITUR § 6:38 (1972))); Young, supra note 92, 265-66 (explaining that while most courts have adopted some type of res ipsa loquitor doctrine, courts are divided on what a plaintiff must show to receive the inference, such as requiring something more than just evidence that an accident occurred).

491. See Haag, supra note 451, at 166, 153 (noting that "all jurisdictions agree that the mere happening of an accident does not justify recourse to the doctrine of res ipsa loquitur." (citing RESTATEMENT (SECOND) OF TORTS § 328D cmt. c (1965))).

492. See id. at 159-60 (citing Fowler V. HARPER ET AL., THE LAW OF TORTS $\S 19.11$ (2d ed. 1986)) (noting that the current confusion over the res ipsa loquitor doctrine, on behalf of both courts and jurors, "may increase a defendant's chance of being subject to a misguided decision." Of course, the rebuttable presumption is distinct from res ipsa loquitor. But the point remains that it is confusion about the doctrine — not the doctrine itself — that may create problems for a defendant). 
standards to be effective. The flexibility from combining reasonable care with a rebuttable presumption is a powerful tool that benefits patrons and ride operators alike - ensuring smooth sailing for the foreseeable future. 